JUAN GONZALO ALIAGA GAMARRA

\title{
ESTUDO PARA A CARACTERIZAÇÃO GENOTÍPICA \\ E FENOTÍPICA DA ATIVIDADE ENZIMÁTICA \\ DA SUBFAMÍLIA CITOCROMO P450 \\ CYP2D6 DE VOLUNTÁRIOS SADIOS
}

Tese apresentada ao Programa de PósGraduação em Farmacologia do Instituto de Ciências Biomédicas da Universidade de São Paulo, para obtenção do Título de Doutor em Ciências. 
JUAN GONZALO ALIAGA GAMARRA

\section{ESTUDO PARA A CARACTERIZAÇÃO GENOTÍPICA \\ E FENOTÍPICA DA ATIVIDADE ENZIMÁTICA \\ DA SUBFAMÍLIA CITOCROMO P450 \\ CYP2D6 DE VOLUNTÁRIOS SADIOS}

Tese apresentada ao Programa de PósGraduação em Farmacologia do Instituto de Ciências Biomédicas da Universidade de São Paulo, para obtenção do Título de Doutor em Ciências.

Área de concentração: Farmacologia

Orientadora: Prof. Dr. Gilberto de Nucci

Versão original 
DADOS DE CATALOGAÇÃO NA PUBLICAÇÃO (CIP)

Serviço de Biblioteca e Informação Biomédica do

Instituto de Ciências Biomédicas da Universidade de São Paulo

(C) reprodução total

Gamarra, Juan Gonzalo Aliaga.

Estudo para a caracterização Genotípica e Fenotípica da atividade enzimática da Subfamília Citocromo P450 CYP2D6 de voluntários sadios / Juan Gonzalo Aliaga Gamarra. -- São Paulo, 2011.

Orientador: Gilberto de Nucci.

Tese (Doutorado) - Universidade de São Paulo. Instituto de Ciências Biomédicas. Departamento de Farmacologia. Área de concentração: Farmacologia. Linha de pesquisa: Farmacogenética.

Versão do título para o inglês: Study to Genotype and Phenotype characterization of enzymatic activity of Subfamily Cytochrome P450 CYP2D6 of health volunteers

Descritores: 1. Polimorfismo 2. Citocromo-P450 3. Farmacogenética 4. Metabolismo de Fármacos 5. Fenótipo 6. Genótipo I. Nucci, Gilberto de II. Universidade de São Paulo. Instituto de Ciências Biomédicas. Programa de Pós-Graduação em Farmacologia III. Título. 
UNIVERSIDADE DE SÃO PAULO

INSTITUTO DE CIÊNCIAS BIOMÉDICAS

Candidato(a): Juan Gonzalo Aliaga Gamarra.

Título da Tese: $\quad$ Estudo para a caracterização Genotípica e Fenotípica da atividade enzimática da Subfamília Citocromo P450 CYP2D6 de voluntários sadios.

Orientador(a): $\quad$ Gilberto de Nucci.

A Comissão Julgadora dos trabalhos de Defesa da Tese de Doutorado, em sessão

pública realizada a considerou

( ) Aprovado(a) ( ) Reprovado(a)

$\begin{array}{ll}\text { Examinador(a): } & \begin{array}{l}\text { Assinatura: } \\ \text { Nome: } \\ \text { Instituição: }\end{array} \\ \text { Examinador(a): } & \begin{array}{l}\text { Assinatura: } \\ \text { Nome: } \\ \text { Instituição: }\end{array} \\ \text { Examinador(a): } & \begin{array}{l}\text { Assinatura: } \\ \text { Instituição: }\end{array} \\ \text { Pssinatura: } & \begin{array}{l}\text { Nome: } \\ \text { Instituição: }\end{array} \\ \text { Assinatura: } & \begin{array}{l}\text { Nome: } \\ \text { Instituição: }\end{array} \\ & \end{array}$ 
UNIVERSIDADE DE SÃO PAULO

INSTITUTO DE CIÊNCIAS BIOMÉDICAS

Cidade Universitária "Armando de Salles Oliveira"

Av. Prof. Lineu Prestes, 2415 - cep. 05508-000 Săo Paulo, SP - Brasil

e-mail:cep@ icb.usp.br

São Paulo, 23 de abril de 2008

\section{PARECER 831/CEP}

Prezado Senhor.

Atendendo sua solicitação, a Comissão de Ética em Pesquisas com Seres Humanos do ICB, $83^{\circ}$ reunião, realizada em 22-abril-08, analisou o projeto de sua responsabilidade intitulado: "Estudo para a caracterização Genotípica e Fenotípica da atividade enzimática da SubFamilia Citocromo P450 CYP2D6 de Voluntários Sadios (GDN-181/04)".

Informo que, após análise do projeto, esta comissão resolveu acatar o parecer favorável do Comitê de Ética em Pesquisa da Faculdade de Ciências Médicas da UNICAMP.

Esclareço a V.Sa. que dentro de 12 meses, relatório do referido projeto deverá ser encaminhado à Secretaria deste CEP.

Atenciosamente,

Prof. Dr. LUIZ VICENTE RIZZO

Coordenador da Comissão de Ética em Pesquisas com Seres Humanos - ICB /USP

IImo. Sr.

JuAN GONZALO ALIAGA GAMARRA

Departamento de Farmacologia

Instituto de Cibencias Biomédicas -USP

Comissão de Ética em Pesquisa com Seres Humanos do Instituto de Ciências Biomédicas I USP Aprovada pela Comissão Nacional de Ética em Pesquisa - CONEP, em 10 de fevereiro de 1998 
A Dios, nuestro Señor Jesús Cristo, por iluminar mi camino en los momentos felices e aciagos; A mi maravillosa esposa Érika, por su amor, dedicación, apoyo, comprensión, compañerismo y enorme paciencia; A mi hijo Juan Guillermo por ser mi regalo Divino; A mis padres Juan y Silvia por la educación, valores e incentivo constantes; A mis hermanos. 


\section{AGRADECIMENTOS}

Ao meu orientador, Prof. Dr. Gilberto de Nucci, pela oportunidade de realizar este sonho, por ter acreditado em minha pessoa, pela sua amizade, pelo apoio financeiro no início e pela constante confiança demonstrada ao longo destes anos.

Ao Prof. Dr. José Luiz Donato, pela sua co-orientação na parte inicial deste estudo e suas importantes apreciações técnicas.

Ao Sr. Mauro Sucupira por ter ensinado e ajudado na parte química do projeto além dos conselhos diários como pessoa e profissional.

Ao laboratório Galeno em Campinas e ao laboratório da Fundação José Tosello, por terem me oferecido os recursos necessários para a execução do projeto.

À Prfa. Dra. Elida Paula Benquique Ojopi e sua aluna M. Sc. Carolina Martins do Prado, pela colaboração e ajuda na realização dos seqüenciamentos.

À Coordenação de Aperfeiçoamento de Pessoal de Nível Superior (CAPES) pela bolsa de estudos concedida.

À Sra. Selma Rigonati, secretária do Departamento de Farmacologia, pela sua eficiência profissional, amabilidade, carisma, bom humor e pronta disponibilidade para solucionar inconvenientes.

Ao pessoal da Biblioteca do ICB pela eficiência, apoio e grande profissionalismo.

À COSEAS, pela bolsa moradia que usufrui por um tempo e pelo restaurante central ("Bandeijão"), que constantemente cuidou da minha alimentação.

Aos meus sogros Conceição e Aparecido pelo carinho, apoio e amizade.

Aos amigos campineiros André Sanfelice, César Pampana, Amanda, Joseane, Aline, Aline Maria, Fabiana, Vilma, entre outros, por sua ajuda e amizade desinteressada e verdadeira.

Aos amigos que passaram pelo laboratório do Prof. José E. Belizário, em especial ao Dayson e a Gladis, amigos leais para a vida toda.

Aos amigos Luis Fernando, Karen, Julio, César, Paola, Miguel, Glenda, Nilton, Adriana, Ricardo e Priscilia pela amizade gratuita e verdadeira ao longo destes anos de convivência. 
"Consider God's handiwork: who can straighten what He hath made crooked?" Ecclesiastes 7:13

"I not only think that we will tamper with Mother Nature, I think Mother wants us to." Willard Gaylin.

"A ambição é o último refúgio do fracasso." Oscar Wilde 


\section{RESUMO}

Gamarra JGA. Estudo para a caracterização Genotípica e Fenotípica da atividade enzimática da Subfamília Citocromo P450 CYP2D6 de voluntários sadios. [tese (Doutorado em Farmacologia)]. São Paulo: Instituto de Ciências Biomédicas da Universidade de São Paulo; 2011.

As enzimas CYP450 são as principais enzimas metabolizadoras de fármacos. Elas são codificadas por genes que apresentam polimorfismos gênicos que lhes confere características fenotípicas diversas. Estes fenótipos são: Metabolizadores Lentos ou PM, Metabolizadores Normais ou EM, Metabolizadores Intermediários ou IM e Metabolizadores Ultra-rápidos ou UM. A Farmacogenética é a ciência que estuda estas variações gênicas e sua relação com a resposta terapêutica no organismo. Entre as enzimas CYP450 se encontram as enzimas CYP2D6, que são responsáveis pelo metabolismo de $25 \%$ dos fármacos clinicamente prescritos. O objetivo principal deste estudo foi a identificação dos polimorfismos mais importantes deste gene: CYP2D6*1,CYP2D6*2,CYP2D6*3,CYP2D6*4,CYP2D6*5, CYP2D6*6, CYP2D6*10, CYP2D6*17 e CYP2D6*41 pelos métodos de Genotipagem (PCR Tetra Primer e Seqüenciamento) e Fenotipagem (analisado pelo Índice Metabólico) em 75 voluntários sadios da região de Campinas. Para a caracterização da Fenotipagem foi usada a substância teste Dextrometorfano (DM). Esta foi monitorada por espectrometria de massa mediante a determinação da concentração do seu principal metabólito o Dextrorfano (DX), que foi extraída das amostras de urina. Os resultados foram comparados entre estas duas metodologias e apresentaram alta correlação. Os resultados obtidos são a identificação das freqüências dos alelos *1, *3 e *4 pelo método PCR Tetra Primer $(30.66 \%, 1.3 \%$ e $14 \%$, respectivamente). $\mathrm{O}$ método de seqüenciamento detectou também outros alelos que não foram detectados pela PCR Tetra Primer. A avaliação do número de cópias do gene CYP2D6 também foi avaliada, detectando em um voluntário 3 cópias do gene CYP2D6, característica de metabolizadores Ultra-rápidos. Podemos afirmar que os métodos usados forneceram perfis dos polimorfismos de maneira rápida e prática.

Palavras-chaves: Polimorfismos. Citocromo P450. Metabolismo de fármacos. 


\begin{abstract}
Gamarra JGA. Study to Genotype and Phenotype characterization of enzymatic activity of Subfamily Cytochrome P450 CYP2D6 of health volunteers. [Ph. D. thesis (Pharmacology)]. São Paulo: Instituto de Ciências Biomédicas da Universidade de São Paulo; 2011.

The CYP450 enzymes are the major drug metabolizing enzymes. They are encoded by genes that show genetic polymorphisms which gives them several phenotypic characteristics. These phenotypes are Poor Metabolizers or PM, or Extensive Metabolizers or EM, Intermediate Metabolizers or IM, and finally, Ultra-rapid Metabolizers or UM. Pharmacogenetics is the science that studies these genetic variations and its relationship to therapeutic response in the body. One of CYP450 enzymes is CYP2D6 enzyme, which are responsible for the metabolism of $25 \%$ of clinically prescribed drugs. The main objective of this study was to identify the most important polymorphisms of this gene: CYP2D6 * 1, CYP2D6 *2, CYP2D6 * 3, CYP2D6 * 4, CYP2D6 * 5, CYP2D6 * 6, CYP2D6 * 10, CYP2D6 * 17 and CYP2D6 * 41 by genotyping methods (PCR Tetra Primer and Sequencing) and phenotyping (by metabolic rate monitoring) in 75 healthy volunteers in Campinas region. To characterize the phenotyping was used to test substance Dextromethorphan (DM). This was monitored by mass spectrometry by determining the concentration of its major metabolite the Dextrorphan (DX), which was extracted from urine samples. The results were compared between these two methods and showed high correlation. We can obtain the identification of allelic frequencies of alleles $* 1, * 3$ and $* 4$ by Tetra Primer PCR $(30.66 \%, 1.3 \%$ and $14 \%$ respectively). The sequencing method has also detected other alleles that were not detected by PCR Tetra Primer. The assessment of the number of copies of the CYP2D6 gene was also assessed. This method detected a volunteer which carrying three copies of CYP2D6 gene, characteristic of Ultra-rapid metabolizers. We can say that the methods used in this study provide polymorphism profiles quickly and conveniently.
\end{abstract}

Keywords: Polymorphisms. Cytochrome P450. Drug metabolism. 


\section{LISTA DE ABREVIATURAS E SIGLAS}

\begin{tabular}{|c|c|}
\hline CYP450 & Citocromo P450 \\
\hline NADPH & Nicotinamida Adenina Dinucleotídeo Fosfato reduzido \\
\hline $\mathrm{NADH}$ & Nicotinamida Adenina Dinucleotídeo reduzido \\
\hline SNP & Polimorfismo de um único nucleotídeo \\
\hline mRNA & Acido Ribonucléico mensageiro \\
\hline cDNA & Biblioteca de DNA complementar \\
\hline DNA & Ácido Desoxirribonucléico \\
\hline EM & Metabolizador Normal \\
\hline PM & Metabolizador Lento \\
\hline UM & Metabolizador Ultra-rápido \\
\hline IM & Metabolizador Intermediário \\
\hline ORF & Seqüência de leitura aberta \\
\hline PCR & Reação em Cadeia da Polimerase \\
\hline $\mathrm{DM}$ & Dextrometorfano \\
\hline $\mathrm{DX}$ & Dextrorfano \\
\hline AUC & Área sob a Curva de Concentração do Fármaco versus Tempo \\
\hline ADR & Reação adversa a fármacos \\
\hline${ }^{\circ} \mathrm{C}$ & Graus Celsius \\
\hline Cmáx & Concentração Plasmática Máxima \\
\hline CYP2D6 & Isoforma 2D6 do Citocromo P450 \\
\hline ddNTPs & Deoxinucleotídeo trifosfatado marcados com Fluorescência \\
\hline DNA & Ácido Deoxiribonucléico \\
\hline dNTP & Deoxinucleotídeo trifosfatado livres em solução \\
\hline DP & Desvio Padrão \\
\hline DX & Dextrorphan - principal metabólito de DM \\
\hline EDTA & Ácido Etilenodiamino Tetra-Acético \\
\hline $\mathrm{HCl}$ & Ácido Clorídrico \\
\hline HPLC & Cromatografia Líquida de Alta Eficiência \\
\hline hs & Horas \\
\hline $\mathrm{kg}$ & Quilogramas \\
\hline
\end{tabular}




\begin{tabular}{|c|c|}
\hline LC-MS-MS & Espectrometria de Massa \\
\hline LOQ & Limite de Quantificação \\
\hline $\mathrm{m}$ & Metros \\
\hline MDR & Resistência a Múltiplas Drogas \\
\hline $\mathrm{mg}$ & Miligrama \\
\hline $\min$ & Minutos \\
\hline $\mathrm{mL}$ & Mililitros \\
\hline $\mathrm{mM}$ & Milimolar \\
\hline $\mathrm{mm}$ & Milímetros \\
\hline mmol & Milimols \\
\hline MRM & Monitoramento de Reações Múltiplas \\
\hline$\mu \mathrm{m}$ & Micrômetros \\
\hline$\mu \mathrm{g}$ & Microgramas \\
\hline$\mu \mathrm{L}$ & Microlitros \\
\hline$\mu \mathrm{M}$ & Micromolar \\
\hline ng & Nanogramas \\
\hline $\mathrm{nM}$ & Nanomolar \\
\hline $\mathrm{pb}$ & Pares de base \\
\hline PCR & Reação em Cadeia da Polimerase \\
\hline PGP & Glicoproteína P \\
\hline $\mathrm{pH}$ & Potencial Hidrogeniônico \\
\hline PI & Padrão Interno \\
\hline QC & Controles de Qualidade \\
\hline s & Segundo \\
\hline SNP & Polimorfismos de um Único Nucleotídeo \\
\hline Tmáx & Tempo em que a Cmáx foi atingida \\
\hline $\mathrm{U}$ & Unidades \\
\hline UV & Ultravioleta \\
\hline $\mathrm{V}$ & Volts \\
\hline Vol & Voluntário \\
\hline
\end{tabular}




\section{SUMÁRIO}

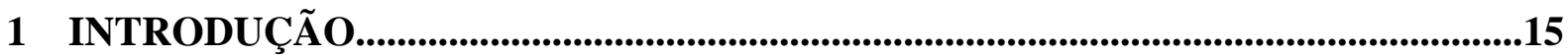

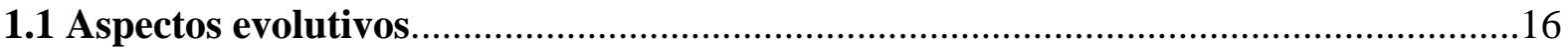

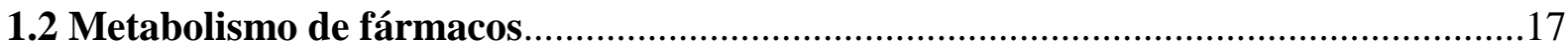

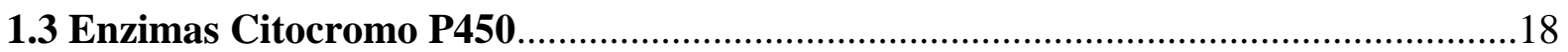

1.4 Farmacogenética e Polimorfismos de DNA …........................................................18

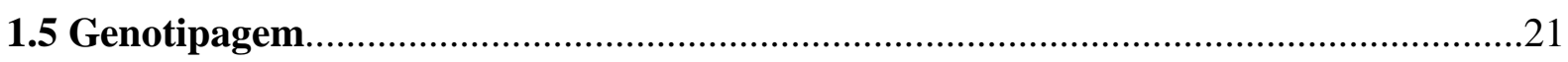

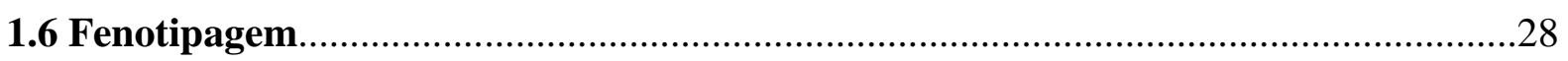

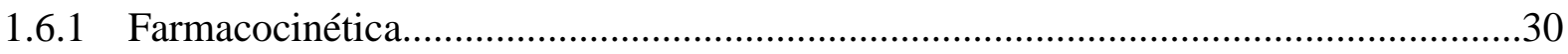

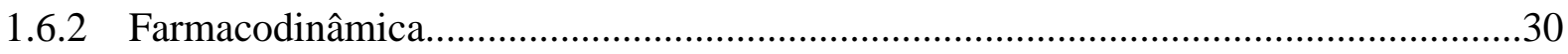

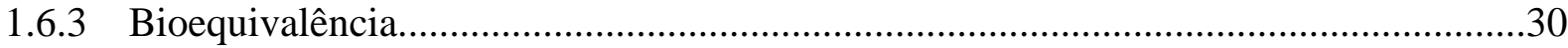

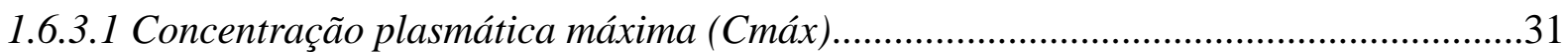

1.6.3.2 Tempo para alcançar a concentração máxima no plasma (Tmáx)..............................31

1.6.3.3 Área sob a curva de concentração plasmática versus tempo (AUC)..........................31

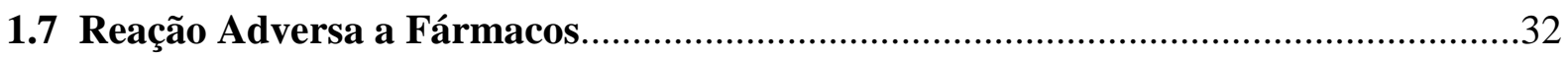

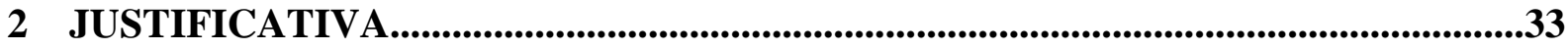

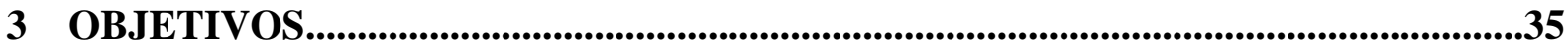

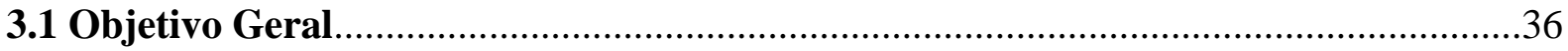

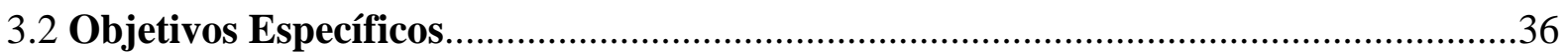

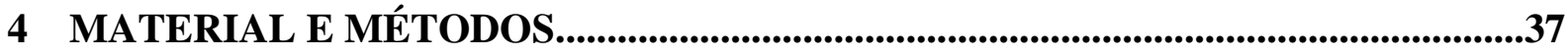

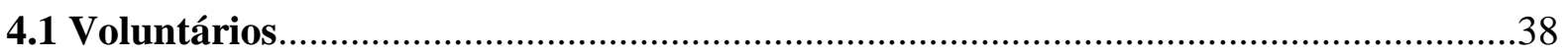

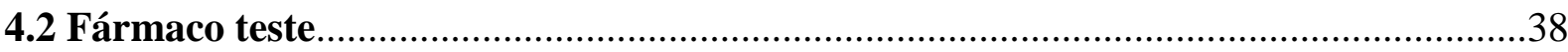

4.3 Comitê de Ética em Pesquisa envolvendo seres humanos..........................................38

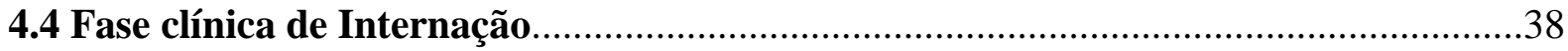

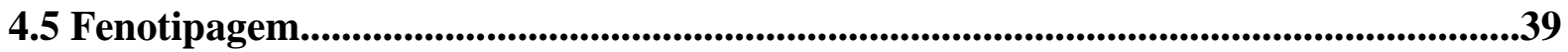

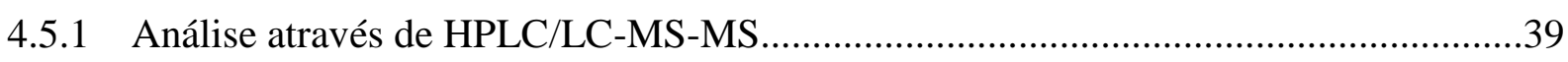

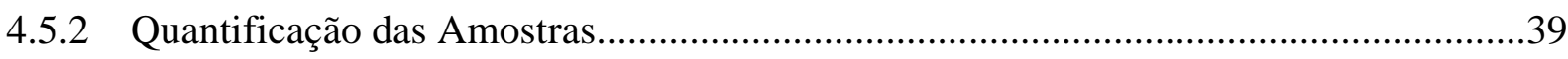

4.5.3 Preparação das Curvas de Calibração........................................................................... 39

4.5.4 Preparação dos Controles de Qualidade (QC)..........................................................40

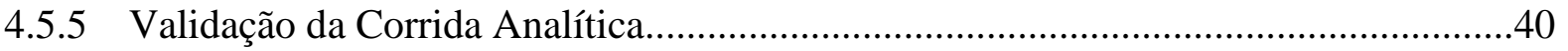

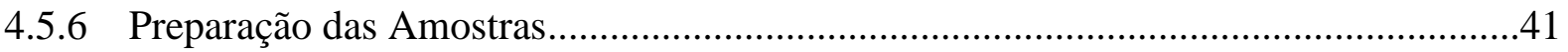


4.5.7 Sistema HPLC / LC-MS-MS.

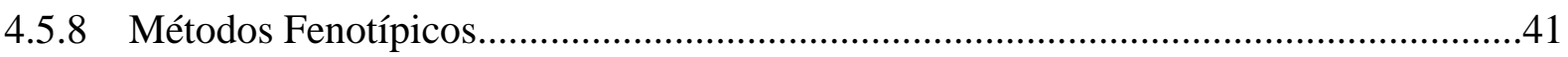

4.5.9 Índice Metabólico de Biotransformação..................................................................42

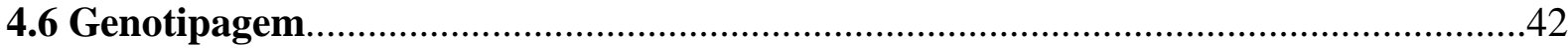

4.6.1 Genotipagem dos alelos $C Y P 2 D 6 * 1, * 3, * 4$, *6 pelo método de Tetra-Primer e alelo CYP2D6*5 pelo método Long PCR …..........................................................42

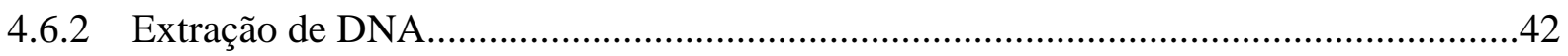

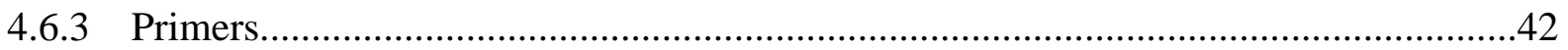

4.6.4 Genotipagem dos alelos CYP2D6*1, *3, *4, *5 e *6...........................................43

4.6.5 Condições da PCR para os alelos CYP2D6*1, *3, *4 $e$ *6........................................43

4.6.6 Condições das Reações da PCR do alelo CYP2D6 *5 .................................................45

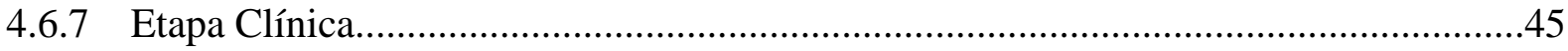

4.6.8 Genotipagem dos alelos *1, *2, *3, *4, *5, *10, *17 e *41, pelo método de Seqüenciamento.

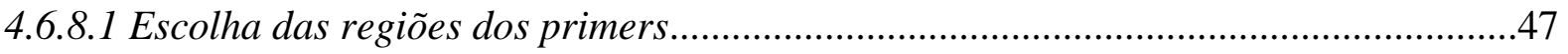



4.6.9 Long template PCR para detecção da duplicação do gene CYP2D6

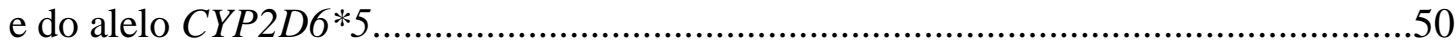

4.6.10 PCR em Tempo Real para a quantificação do número de Cópias do gene $C Y P 2 D 6$.

4.6.11 Determinação dos fenótipos preditos pelo

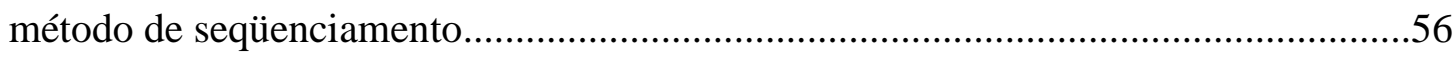

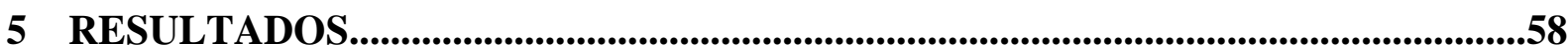

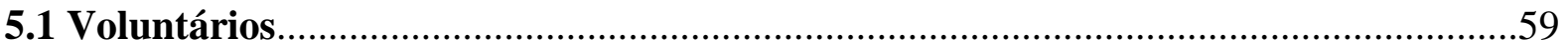

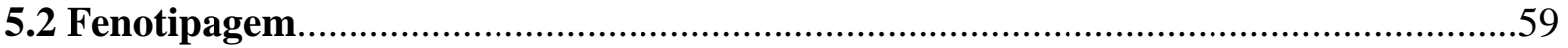

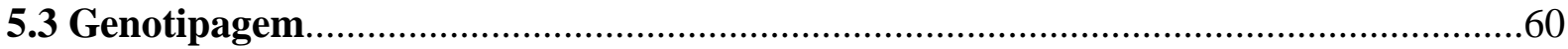

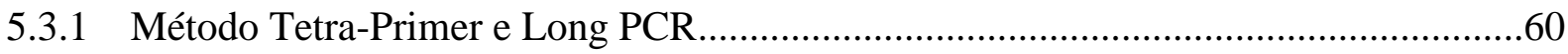

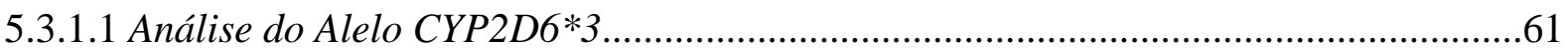

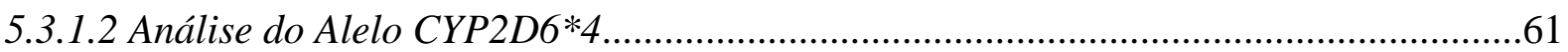

5.3.1.3 Análise dos Alelos CYP2D6*3 e *4 em conjunto .......................................................62

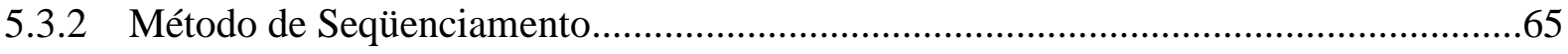

5.3.2.1 Análise dos Alelos CYP2D6*1, *2, 3, *4, *5, *10, *17, e

*41 e seu número de cópias. 
5.3.3 Comparação dos resultados pelos métodos de Seqüenciamento.

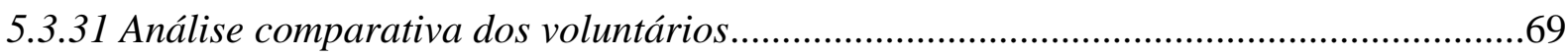

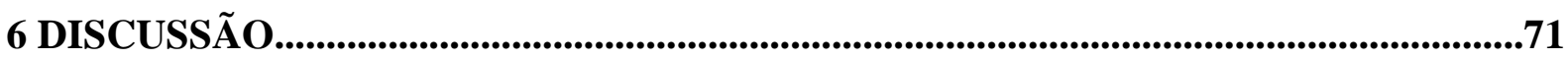

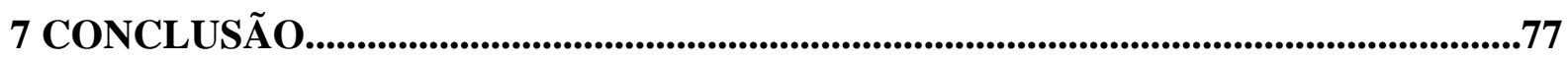

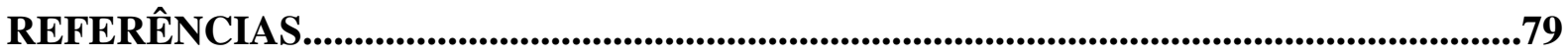

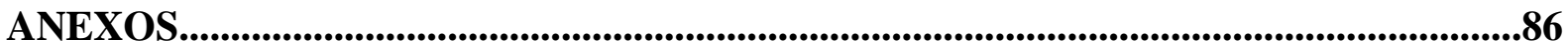

ANEXO A - Termo de Consentimento............................................................................

ANEXO B - Índice Metabólico de Biotransformação........................................................90

ANEXO C - Eletroferogramas de alguns alelos.....................................................................92

ANEXO D - Haplótipos das amostras seqüenciadas......................................................93 


\subsection{Aspectos evolutivos}

As enzimas monoxigenases Citocromo P450 ou CYP450 (do inglês Cytochrome P450) são parte de uma enorme família ou "superfamília" de enzimas microssomais que, acredita-se, existem há 3.5 bilhões de anos. Organismos primários, provavelmente, usaram estas enzimas para metabolizar ou sintetizar moléculas esteróides importantes para a integridade da sua membrana celular ${ }^{1}$. Estas enzimas são encontradas em diversos organismos, incluindo bactérias, plantas e animais, implicando a existência de um ancestral comum antes da divergência eucariota-procariota ${ }^{2}$. Estas enzimas apresentam, principalmente, duas funções importantes: a biossíntese de compostos endógenos (xenobióticos) e o metabolismo de fármacos. Para poder realizá-las, elas utilizam os elétrons provenientes da molécula nicotinamida adenina dinucleotídeo fosfato reduzido (NADPH) ou, algumas vezes, a partir de nicotinamida adenina dinucleotídeo reduzido (NADH) para a ativação de oxigênio molecular. A sua capacidade de ativar o oxigênio molecular e posteriormente de inserir um átomo de oxigênio em um substrato foi explorado por muitos organismos para diversos propósitos $^{2}$.

A função de metabolizar compostos exógenos apareceu, provavelmente, há 400 a 500 milhões de anos e, acredita-se, que esta função foi desenvolvida para a detoxificação celular de compostos químicos de origem vegetal tais como alcalóides, entre outros ${ }^{1}$.

As enzimas CYP450 são os agentes oxidantes mais poderosos in vivo, capazes de realizar a oxidação de uma grande variedade de substratos química e biologicamente não relacionados ${ }^{3,4,5}$. Acredita-se que estas enzimas humanas estão envolvidas na oxidação de 7090\% dos fármacos utilizados clinicamente, e também participam do metabolismo de um vasto número de agentes químicos como carcinogênicos e pesticidas ${ }^{6}$. Algumas das CYP450 são extra-hepáticas e têm importante função em diversas vias de síntese, incluindo a biossíntese de esteróides nas glândulas supra-renais e a biossíntese de prostaciclinas e tromboxanos entre outros compostos ${ }^{7,8}$.

A maioria dos fármacos lipossolúveis (hidrofóbicos) que ingressa em nosso organismo sofre dois processos de eliminação bem conhecidos, a excreção e o metabolismo. Os principais órgãos através dos quais os fármacos e seus metabólitos são removidos do corpo 
são os rins, o sistema hepatobiliar e os pulmões ${ }^{9,10}$. Outros órgãos com capacidade metabólica significativa incluem o trato gastrintestinal, pâncreas, cérebro, pulmão, glândulas adrenais, rins, medula, mastócitos, pele, ovários e testículos ${ }^{11}$. Os compostos hidrofóbicos não são eliminados eficientemente pelo rim. Portanto, a maioria dos fármacos lipofílicos é convertida a produtos mais polares (com maior hidrossolubilidade), posteriormente são excretadas na urina. O metabolismo destes compostos ocorre principalmente no fígado pelo sistema enzimático CYP450 ${ }^{12}$, e por outras enzimas não microssomais ${ }^{9}$.

\subsection{Metabolismo de fármacos}

O metabolismo dos fármacos envolve duas classes de reações bioquímicas, de Fase I e de Fase II que acontecem, principalmente, no fígado. Alguns destes fármacos também são metabolizados no plasma, pulmão ou no intestino. As reações de fase I se caracterizam por aumentar a polaridade dos compostos lipofílicos e, geralmente, consistem de reações químicas como oxidação, redução e hidrólise, e os produtos são, com frequiência, mais reativos e, paradoxalmente, mais tóxicos ou mais carcinogênicos que os fármacos originais ${ }^{13,14,15}$. As reações de fase II envolvem a conjugação (glicuronidação, sulfonação, entre outros, e inclusive a adição de aminoácidos) que, geralmente, resultarão em compostos inativados. Com freqüência, as reações da fase I introduzem um grupo relativamente reativo, como por exemplo, o grupo hidroxila, na molécula (processo chamado de funcionalização). Posteriormente, este grupo funcional serve como ponto de ataque para o sistema de conjugação, fixando um substituinte como glicuronídeo. Em geral, ambas as etapas diminuem a lipossolubilidade, aumentando assim a eliminação renal do fármaco ${ }^{9,10,15}$.

Muitas enzimas hepáticas envolvidas no metabolismo de fármacos -incluindo as CYP450- encontram-se no retículo endoplasmático liso e são conhecidas como enzimas microssomais. Para atingir essas enzimas metabolizadoras, o fármaco precisa atravessar a membrana plasmática do hepatócito. As moléculas polares fazem isso mais lentamente do que as moléculas não polares, exceto quando existem mecanismos específicos de transporte, de modo que o metabolismo hepático é, em geral, menos importante para fármacos polares que para os lipossolúveis. A excreção se dá, em maior proporção, do fármaco na forma inalterada na urina que do seu metabólito9 9 


\subsection{Enzimas Citocromo P450}

As enzimas CYP450 são proteínas monooxigenases que possuem um grupo heme e possuem propriedades redox únicas, as quais são fundamentais para as suas diversas funções. Compreendem uma superfamília de enzimas relacionadas, porém distintas, que diferem uma da outra pela sequiência de aminoácidos, na regulação por inibidores e agentes indutores e na especificidade das reações que catalisam ${ }^{16,17}$. Todas estas enzimas são produtos da mesma

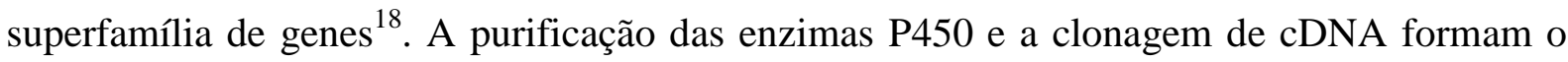
esqueleto do atual sistema de classificação, que é baseada nas semelhanças das seqüências de aminoácidos ${ }^{19}$.

$\mathrm{O}$ seqüenciamento do genoma humano mostrou a presença de 57 genes funcionais e 58 pseudogenes $^{20,21}$ dispostos em 18 famílias (enzimas que compartilham uma identidade $\geq$ de $40 \%$ ) e 42 subfamílias (enzimas que compartilham uma identidade $\geq 55 \%$ ). São três famílias principais (Famílias 1, 2 e 3) as responsáveis pelo metabolismo de fármacos terapêuticos $^{11,22}$.

A nomenclatura das CYP450 que é usada por convenção é a que seguiremos neste trabalho. Usaremos como exemplo a denotação do gene $C Y P 2 D 6 * 4$. Aqui observamos a sigla CYP, esta se refere ao citocromo P450. Logo continua o número 2 que significa o número da família, depois prossegue a letra $\mathrm{D}$ que identifica a subfamília, seguido do número 6 que indica a isoenzima 6. A continuação vem o símbolo estrela (asterisco) que indica uma variante alélica, é seguido de um número correspondente à variante alélica, neste exemplo $4^{23}$.

As diferentes isoformas das enzimas CYP450 variam em abundância dentro do fígado, embora as proteínas CYP2C9, CYP2D6 e CYP3A4 estão envolvidos em 70 - 80\% de todas as oxidações metabólicas de Fase I dos fármacos clinicamente prescritos ${ }^{6,24}$.

\subsection{Farmacogenética e Polimorfismos de DNA}

A farmacogenética é a ciência que estuda a existência de variações nas seqüências de DNA que possam alterar a maneira como o nosso organismo responde ao tratamento com 
fármacos. De maneira geral, estas variações podem acontecer em genes que codificam para transportadores de fármacos, enzimas envolvidas no metabolismo de fármacos ou a proteínas que estão relacionados com o alvo de fármacos ${ }^{25}$. A farmacogenética ostenta o potencial de identificar um fármaco em particular e a dose deste que será o mais adequado para se obter um efeito terapêutico bem sucedido para cada paciente. Este é um dos principais objetivos da moderna terapia com fármacos, a qual é descrita como a "medicina personalizada",26, 27.

Em todos os organismos ocorrem variações naturais na seqüência do DNA do genoma. Foi estimado que em seres humanos diferenças de nucleotídeos entre indivíduos podem ser detectadas mais ou menos a cada 200 nucleotídeos. Essas variações na sequiência do DNA são conhecidas como polimorfismos. A definição do termo polimorfismo foi mudando com o decorrer do tempo. Em 1971 se definia como alguma situação onde os membros de uma população podem apresentar distintos fenótipos, onde os fenótipos têm uma apreciável incidência maior que $2 \%^{28}$. Atualmente, o termo polimorfismo é usado para descrever variantes alélicas que são detectadas em mais de $1 \%$ da população ${ }^{29}$.

A origem dos polimorfismos se deve a existência de mutações espontâneas ou não na seqüência de DNA, sendo que algumas destas mutações ocorrem nas sequiências codificadoras, levando à produção de seqüências protéicas defeituosas. Outras ocorrem em seqüências não-codificadoras que, geralmente, não afeta a expressão gênica. Em muitos organismos e incluindo seres humanos, os polimorfismos parecem estar associados a mudanças em apenas uma base (chamados de SNPs do inglês Single Nucleotide Polymorphism ou polimorfismo de um único nucleotídeo), e geralmente próximos aos sítios com seqüência do dinucleotídeo CG. Conseqüentemente, sítios de clivagem de enzimas de restrição que contenham esse dinucleotídeo são geralmente polimórficos, podendo ser facilmente detectadas e amplificadas pela técnica Reação em Cadeia da Polimerase (PCR), utilizando seqüências de DNA franqueadoras específicas como iniciadoras (primers). Por outro lado, sequiências repetidas polimórficas darão origem a variantes alélicas diferentes e, portanto, serão de uso mais geral no mapeamento de loci de doenças ${ }^{30,31,32}$.

Todos os genes que codificam para as diversas enzimas CYP450 das famílias 1 a 3 são polimórficos, mas os genes polimórficos clinicamente mais importantes são $C Y P 2 C 9$, CYP2C19 e CYP2D6 sendo que os genes CYP1A1 e CYP2E1 são relativamente menos 
polimórficos no ser humano ${ }^{33}$. Este polimorfismo gênico gera respostas interindividuais diversas devido à constante exposição a agentes químicos na população, causando em muitos casos, vários tipos de patologias. Devido principalmente à grande abrangência das diferentes enzimas CYP450 a seus substratos são usados no tratamento de depressão, pânico, psicose, desordens gastrintestinais e/ou úlceras, câncer, desordens cardiovasculares e epilepsia ${ }^{17}$.

As mutações nos genes CYP450 podem codificar para enzimas com atividades nula, reduzidas, alteradas ou incrementadas. A atividade nula geralmente é observada quando o gene é deletado, mas também por diversas causas como amadurecimento do mRNA (splicing) alterado, códons de parada, sítios de início transcricional abolido e trocas para aminoácidos deletérios. A atividade reduzida é observada quando há uma mutação nos sítios de reconhecimento de substrato, causando a síntese de enzimas com especificidade alterada para o substrato, este fenótipo é também evidenciado quando acontece uma mutação no sítio de dobragem ou folding. O incremento da atividade é observado em pacientes que carregam uma ou mais cópias de um gene ativo da $C Y P 450^{33}$. A evidência deste polimorfismo significa que a capacidade metabólica do sistema das enzimas CYP450 não é igual em todos os indivíduos de uma população. Como resultado disto, os índices de conversão metabólica e de excreção dos fármacos varia entre indivíduos em condições que vão desde extremamente lento até ultra-rápidos ${ }^{16,22,34}$.

De acordo a uma classificação convencional de fenótipos baseados na aceitação das relações de dominância e recessividade alélicas, sendo que o fenótipo é determinado pelo haplótipo (combinação completa de polimorfismos em um cromossomo) mais eficiente do genótipo $^{35}$. Podem ser identificados quatro fenótipos mediante o uso de técnicas de genotipagem: Metabolizadores Lentos (PM de poor metabolizers) são aqueles que carecem da enzima funcional; metabolizadores intermediários (IM de intermediated metabolizers) que são heterozigotos para um alelo deficiente ou carregam dois alelos que causam atividade reduzida; metabolizadores extensivos ou normais (EM de extensive metabolizers) que têm dois alelos selvagens; e Metabolizadores ultra-rápidos (UM de ultrarapid metabolizers) que têm duas ou mais cópias do mesmo gene funcional com atividade intensa, uma característica de herança dominante ${ }^{17,21}$. Para as pessoas que apresentam o fenótipo PM, o tratamento com doses normais causará aumento das concentrações plasmáticas do metabólito atingindo até níveis tóxicos, observando-se, portanto, um acúmulo do fármaco no organismo, podendo 
causar sérias conseqüências ${ }^{36}$. No grupo de pessoas que apresentam o fenótipo UM, o tratamento com doses normais de um fármaco não atingirá o efeito farmacológico esperado, pois este será metabolizado muito rapidamente, impossibilitando o sucesso terapêutico. Isto pode ser observado na Figura 1, onde a relação genótipo-fenótipo e suas consequiências farmacocinéticas e clínicas são mostradas ${ }^{37}$.

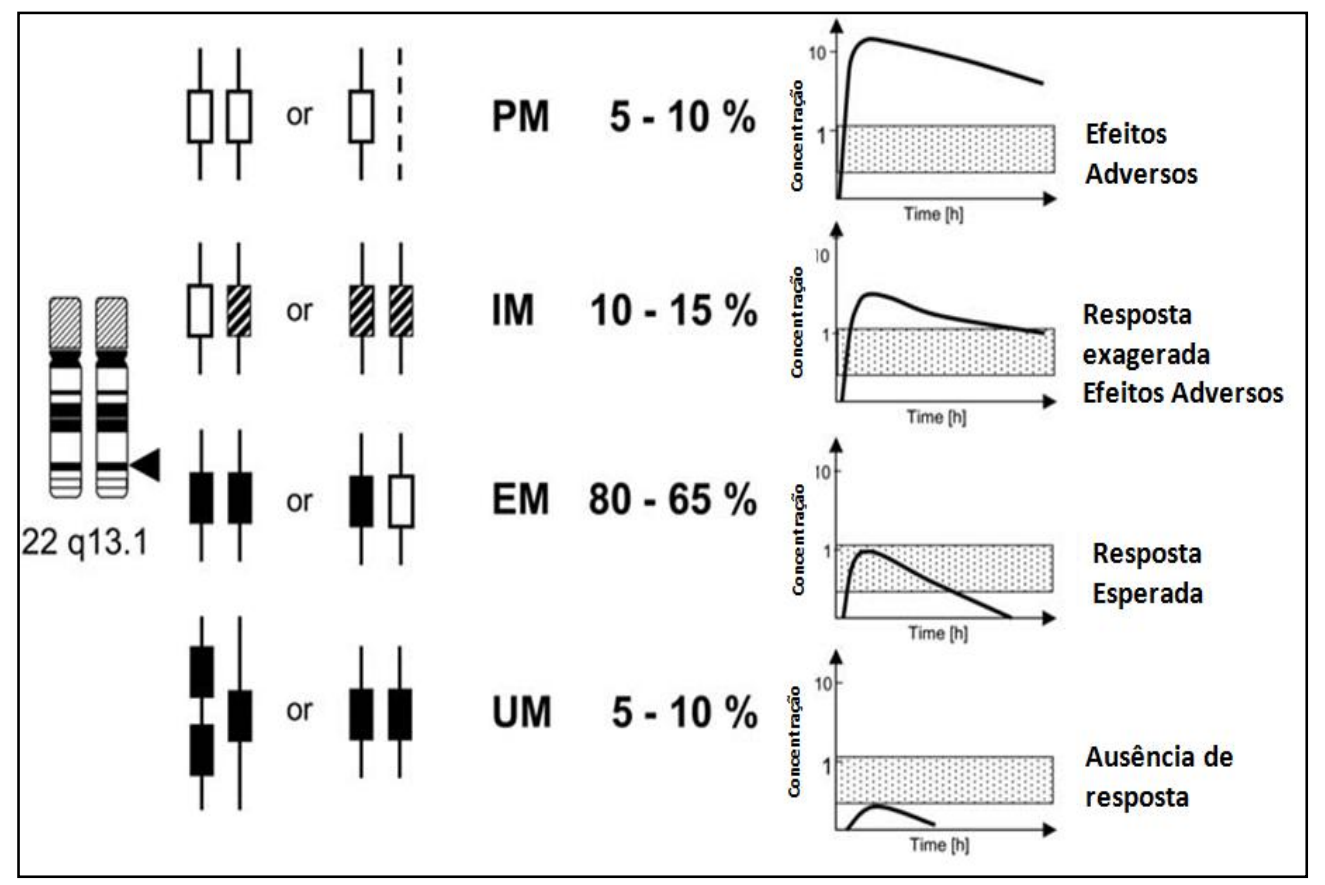

Figura 1. Esquema onde se evidencia a forte relação genótipo-fenótipo. A partir do esquema do cromossoma humano onde se localiza o gene CYP2D6, se observam os alelos e suas possíveis combinações que podem evidenciar um fenótipo específico. Alelos nulos são representados com caixas brancas, alelos funcionais normais com caixas pretas e alelos com função alterada com caixas riscadas. O porcentual de cada fenótipo é de uma população caucasiana.

Fonte: Adaptado de Zanger, 2004.

\subsection{Genotipagem}

Aproximadamente 20 - 25\% do metabolismo de todos os fármacos da fase I são realizados pela enzima CYP2D6 ${ }^{21}$ (Figura 2). O gene CYP2D6 está localizado no cromossomo 22q13.1. O lócus contém dois pseudogenes vizinhos, CYP2D7 e CYP2D8 formando um cluster. A evolução do lócus $C Y P 2 D$ envolveu a eliminação de três genes e a inativação de dois (CYP2D7 e CYP2D8) e a parcial inativação de um gene $C Y P 2 D 6^{38}$. 


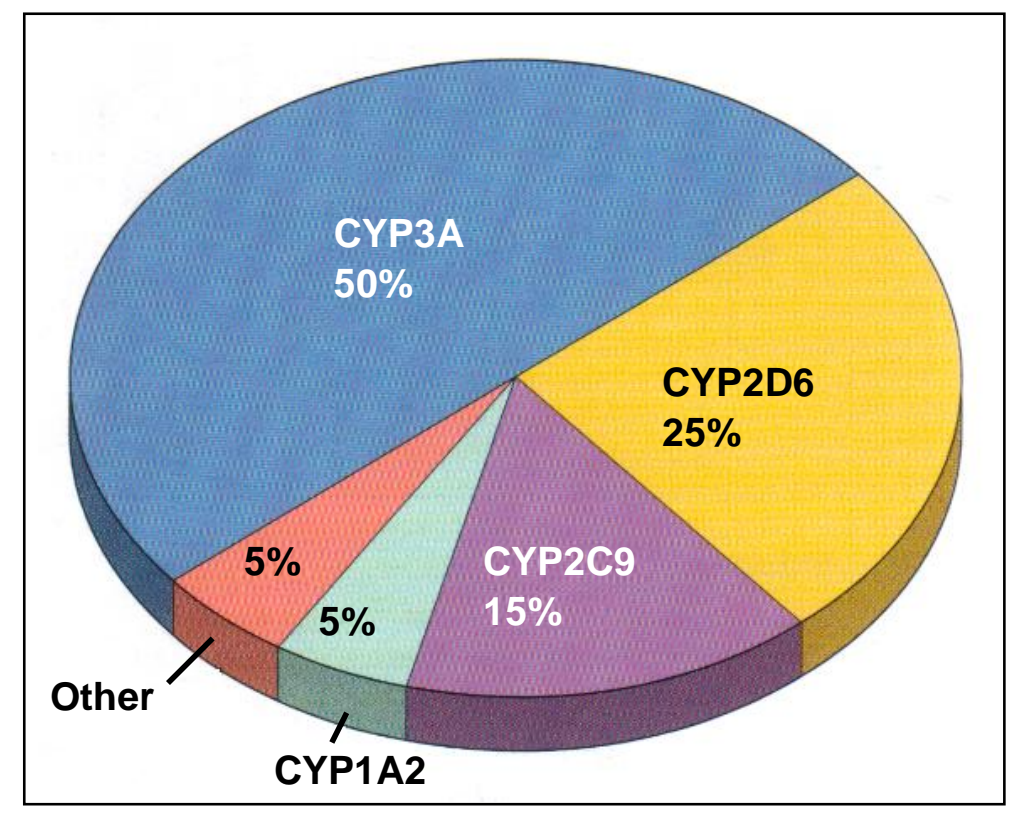

Figura 2. Diversos Genes CYP450 e seu porcentual de metabolismo de fármacos mais prescritos clinicamente nos Estados Unidos de América.

Na atualidade, 74 alelos polimórficos diferentes do gene $C Y P 2 D 6$ foram descritos na literatura. $\mathrm{O}$ gene consiste de 9 éxons e 8 íntrons, com uma seqüência de leitura aberta ou ORF (do inglês Open reading Frame) de 1491 pares de bases que, por sua vez, codificam para um polipeptídeo de 497 aminoácidos ${ }^{21}$. A enzima é parte de uma pequena porcentagem de todas as CYP450 hepáticas $(2-4 \%)$, porém seu papel no metabolismo de fármacos é muito maior do que sua porcentagem relativa ${ }^{21,35}$. Antes da cristalização da CYP2D6, a idéia que se tinha sobre a sua estrutura era baseada na estrutura tridimensional do citocromo P450 BM-3 ou CYP2C5. Porém, o uso de algumas técnicas como mutação sítio dirigida e também aleatória mostraram que elas mantinham muitas diferenças moleculares entre $\mathrm{si}^{14,38}$. Contudo, em 2006 foi publicada a cristalização desta enzima em humanos ${ }^{39}$. A expressão foi realizada em modelo bacteriano (Escherichia coli), e a análise cristalográfica revelou aspetos desconhecidos na época. A enzima CYP3A4 apresenta maior afinidade por muitos substratos, geralmente atribuído a sua grande cavidade de sítio de ligação, a CYP2D6 reconhece só substratos que contenham nitrogênio básico protonado e um anel aromático planar. Esta característica é encontrada em grande número de fármacos do sistema nervoso central e Sistema cardiovascular, que agem na superfamília de proteínas de receptores acoplados a proteínas G. Portanto, antes desta publicação, o que se tinha como referência de estrutura da CYP2D6 era pela comparação com isoformas cristalizadas de CYP2C e CYP3A4, que mostravam uma homologia de $40 \%$ e $18 \%$, respectivamente (Figura 3$)^{39}$. Hoje se sabe que a 
reação de hidroxilação das CYP2D6 acontecem a uma distância de aproximadamente 5 a 7 $\AA^{17,37}$. Atualmente existem trabalhos in silica de modelos computacionais desta enzima que visam poder fazer previsões de sítio metabólico para substratos novos ${ }^{40}$.

Um aspecto importante que diferencia esta enzima das outras CYP450 é o fato de não ser regulado por nenhum agente ambiental e não é induzível por nenhum hormônio. Outra característica foi a respeito do fenótipo deste gene em sujeitos que carecem da enzima e entre sujeitos com inclusive 13 cópias do mesmo gene, isto leva a concluir que a CYP2D6 não tem uma função endógena importante. Para muitos fármacos, especialmente os psicotrópicos, se considera a CYP2D6 como uma enzima de alta afinidade e de baixa capacidade, isto implica que esta enzima metabolizará, preferencialmente, os fármacos a concentrações mais baixas ${ }^{38}$.

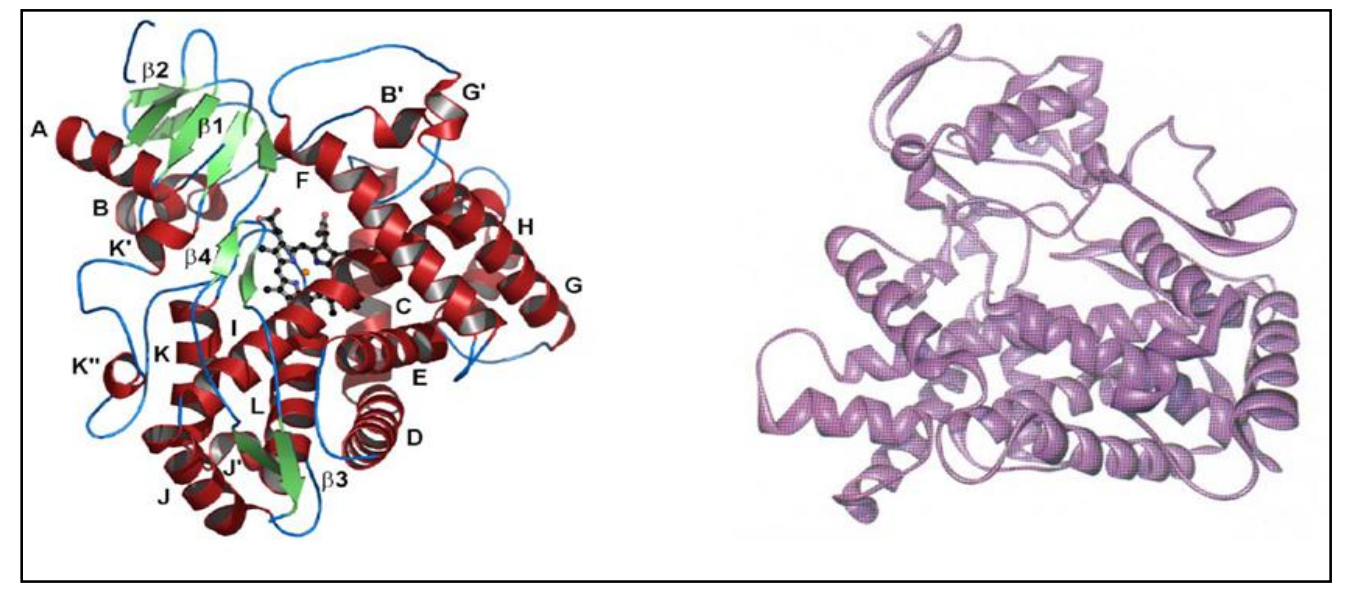

Figura 3. Diagramas representando dois modelos cristalográficos. À esquerda, a estrurura da enzima CYP2D6, à direita a estrutura da enzima CYP2C9. Nota-se a diferença entre as duas estruturas, especialmente do sítio de ligação de substrato, sendo da enzima CYP2D6 menor em tamanho.

Fonte: Adaptado de Rowland, 2006.

Com o decorrer do tempo, desenvolveram-se várias técnicas que permitem identificar o polimorfismo dos genes CYP450. Estas técnicas são usadas para caracterizar o polimorfismo de um único nucleotídeo ou para detectar variantes alélicas em amostras de DNA genômico de humanos. Estas técnicas incluem: seqüenciamento direto, métodos baseados na extensão de primers (primer extension), métodos de hibridação (que incluem “Chips" de DNA de vários tipos) e, análise com enzimas de restrição entre outras ${ }^{41}$. As técnicas mais utilizadas são: Estudos de restrição por Polimorfismo no comprimento de fragmentos de restrição ou RFLP (Restriction fragment length polymorphism), geralmente 
depois de ter amplificado uma região específica de um dos genes da P450 pela técnica PCR, amplificação de um alelo específico pelas técnicas ARMS (The amplification refractory mutation system em inglês) e Tetra Primer ${ }^{42,43,44,45}$ que permitem genotipar polimorfismos de nucleotídeos pontuais, a técnica de Multiplex $\mathrm{PCR}^{46}$ e a técnica de Real Time $\mathrm{PCR}^{47,}$. Atualmente, têm sido desenvolvidas técnicas que permitem analisar muitos SNPs e de vários genes CYP450 ao mesmo tempo, usando técnicas de espectrometria de massa MALDI-TOF ${ }^{49}$ (do inglês, Matrix Assisted Laser Desorption/Ionisation Time Of Flight) e que já foi usada para a análise de 50 SNPs dos genes CYP2D6, CYP2C19, CYP2C9, CYP3A4 e CYP1A2 ${ }^{50}$.

Existe correlação entre as diferenças étnicas e a distribuição dos fenótipos EM, PM e UM. Os PM estão presentes em aproximadamente 5 - 14\% dos caucasianos. Em asiáticos, africanos e afro-americanos tem uma alta porcentagem de diminuição de função ou sem nenhuma função (entre $40 \%$ e 50\%) do que dos caucasianos (26\%) para a enzima CYP2D6. Os fenótipos UMs apresentam uma duplicação completa funcional do alelo CYP2D6, que resulta em maiores níveis de enzimas CYP2D6. Devido a estes níveis enzimáticos maiores, os UMs precisam de uma dose maior para manter um nível terapêutico do fármaco no sangue. Os UMs são geralmente raros e representam $1-3 \%$ da população caucasiana ${ }^{11,17}$.

Em um estudo realizado por Sistonen et al. em 2007, foram genotipados 1060 indivíduos de diferentes regiões do planeta, agrupados em oito regiões geográficas: África subsaariana, África do norte, Oriente médio, Europa, Ásia central/sul, Este da Ásia, Oceania, e América. Eles analisaram um grande número de haplótipos do gene CYP2D6 (*1, *2, *3, $* 4, * 5, * 6, * 9, * 10, * 17, * 29, * 39$ e *41, assim como o número de cópias destes genes. Os resultados mostraram que Europa apresentava uma grande freqüência de fenótipo PM (8\%), e foi o único continente que apresentou uma distribuição bimodal. Nos outros casos a distribuição foi unimodal, mas a única característica comum foi a predominância do fenótipo EM. O segundo maior grupo metabólico em América do Norte, Oceania, foi o fenótipo UM (40, 26, 12 e 8\%, respectivamente). Ademais, indivíduos da Oceania e americanos se enquadraram nos fenótipos UM ou EM, que prevê alta capacidade metabólica, enquanto o fenótipo PM foi completamente ausente. As variantes alélicas comuns de função diminuída, tais os casos dos alelos *10, *17 e *41, mostraram um número maior de fenótipo IM no Este da Ásia, África e Oriente Médio quando comparados a outras regiões, um fato já conhecido 
mas, a genotipagem do haplótipo *41 permitiu identificar um número relevante de fenótipos IM no Oriente Médio ${ }^{35}$ (Figura 4) .

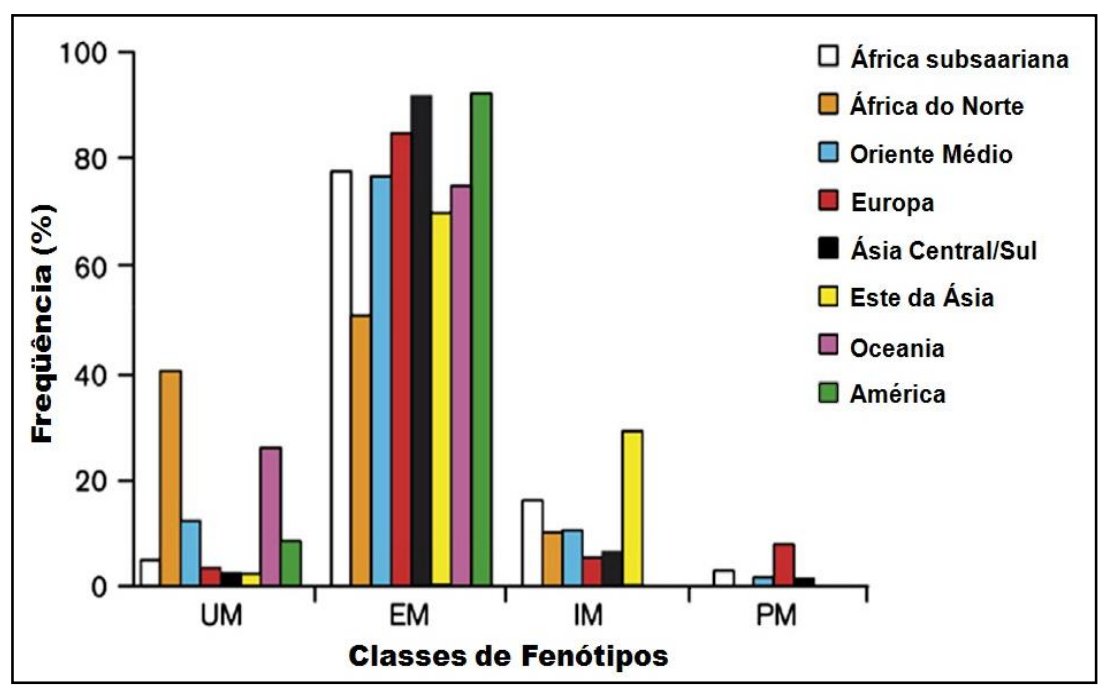

Figura 4. São mostradas as freqüências das classes de fenótipos em diferentes regiões geográficas. Os fenótipos foram previstos a partir dos genótipos. UM: Metabolizadores ultrarápidos; EM: Metabolizadores Normais ou completos; IM: Metabolizadores intermediários; PM: Metabolizadores lentos.

Fonte: Adaptado de Sistonen, 2007

As variantes alélicas nulas que não codificam para uma enzima funcional e que não apresentam nenhuma atividade enzimática residual detectável e que se correlacionam com o fenótipo PM são *3, *4, *5, *6, *7, *8, *11, *12, *13, *14, *15, *16, *18, *19, *20, *21, *38, $* 40, * 42, * 44, * 56$ e *62. Sendo que os alelos *3, *4, *5 e *6 compreendem quase $97 \%$ dos alelos que causam o fenótipo PM em caucasianos ${ }^{21}$.

O alelo *2 apresenta duas mutações, a primeira na posição 1661 do íntron 3, trocando a $\mathrm{G}$ por $\mathrm{C}(1661 \mathrm{G}>\mathrm{C})$ e a segunda na posição 2850 do íntron 6 , trocando a $\mathrm{C}$ por $\mathrm{T}$ $(2850 \mathrm{C}>\mathrm{T})$. Apresenta uma troca de $\mathrm{C}$ por $\mathrm{G}$ na posição $1548(1548 \mathrm{C}>\mathrm{G})$, e esta mudança leva a substituição de dois aminoácidos, um na posição 296 (mRNA) de Arginina para Serina (R296C), a segunda na posição 486 (mRNA) de Serina para Treonina (S486T).

O alelo *3 contém uma deleção de Adenina (A) na posição 2549 do éxon 5, levando a uma ruptura do marco de leitura do mRNA, sem a produção da enzima. O impacto funcional deste alelo ainda é desconhecido. 
$\mathrm{O}$ alelo *4 tem uma freqüência de $22 \%$, e em algumas populações como a sueca, representa $75 \%$ dos alelos mutantes. Entretanto, apresenta uma baixa frequiência na população chinesa $(\sim 1 \%)$ e africana $(3,9 \%)$. Este alelo apresenta uma mutação na posição 100 , trocando a citosina $(\mathrm{C})$ pela timina $(\mathrm{T})(\mathrm{C}>\mathrm{T})$ e também outra mutação na posição 4180 , trocando a guanina $(\mathrm{G})$ por $\mathrm{C}(4180 \mathrm{G}>\mathrm{C})$.

$\mathrm{O}$ alelo *5 se refere à deleção do gene inteiro e sua freqüência (4-7\%) é similar em diferentes grupos étnicos. Este alelo é o segundo alelo de inativação mais comum na população do Reino Unido e a freqüência nas populações caucasianas é de $4 \%$.

O alelo *6 apresenta uma deleção na posição 1707 que impede a formação da enzima.

Os alelos *10, *17, *41 apresentam uma atividade significativamente diminuída atribuída a uma pouca estabilidade da enzima, alteração no reconhecimento do substrato e a diminuição da afinidade enzima-substrato. A mudança da atividade enzimática pode ser substrato-dependente como é o caso do alelo *17.

Geralmente os indivíduos apresentam um fenótipo PM ou IM. O alelo *10 acontece em 33-43\% dos asiáticos, incluindo japoneses, coreanos e chineses e residentes das ilhas do pacífico. No entanto, este alelo apresenta uma baixa freqüência em caucasianos, afroamericanos e outros grupos populacionais como índios e ameríndios $(2-5 \%)$. Sujeitos homozigotos $* 10 / * 10$ precisam de doses menores de fármacos como metoprolol do que sujeitos homozigotos selvagens $* 1 / * 1$ para poder atingir o mesmo efeito terapêutico.

O alelo *17 apresenta freqüências altas em africanos e afro-americanos, mas é praticamente ausente em caucasianos. As freqüências são variáveis, dependendo do país de origem, sendo de 34\% para residentes de Zimbábue, 17 para os de Tanzânia, 28\% para os Ganeses e $9 \%$ para os etiopianos. Mais de 10\% de zimbabuenses são homozigotos para este alelo.

$\mathrm{O}$ alelo *41 é uma variante do alelo *2, também apresenta uma troca de C por $\mathrm{G}$ na posição 1548 (1548C >G), e esta mudança leva a substituição de dois aminoácidos, um na posição 296 (mRNA) de Arginina para Cisteína (R296C), a segunda na posição 486 (mRNA) de Serina para Treonina (S486T). Dois estudos recentes têm demonstrado que a substituição 1548C >G se encontra em desequilibrio de ligação com o polimorfismo 2988G>A, ocasionando um splicing defeituoso do mRNA. No entanto, os indivíduos homozigotos para 
CYP2D6 são fenotipicamente similares a IMs com um único alelo deficiente. Os alelos $C Y P 2 D 6 * 2$ e $C Y P 2 D 6 * 41$ são os haplótipos mais comuns que apresentam duplicação e multiduplicação, como resultado de pressão seletiva, que pode haver acontecido na África do Norte $^{21}$. A Figura 5 mostra um esquema com os diferentes sítios de mutação, analisados neste estudo, correlacionados com seus respectivos haplótipos e, ainda, o efeito que elas causam na atividade enzimática ${ }^{35}$.

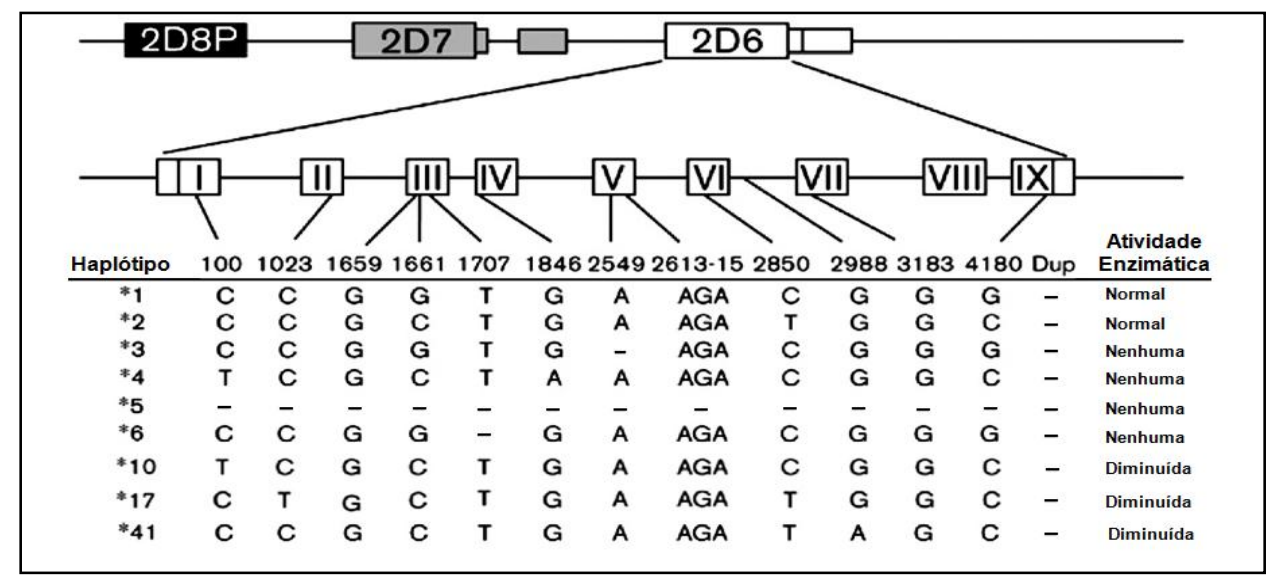

Figura 5. Esquema das variantes alélicas do gene CYP2D6 com suas respectivas atividades enzimáticas. Mostra-se somente os haplótipos analisados neste trabalho.

Fonte: Figura adaptada de Sistonen, 2007.

A Figura 6 mostra um esquema onde se comparam os alelos $C Y P 2 D 6 * 1$ (selvagem) e o alelo $C Y P 2 D 6 * 2$. Notam-se, ainda, as substituições ou trocas de aminoácidos no alelo *2.

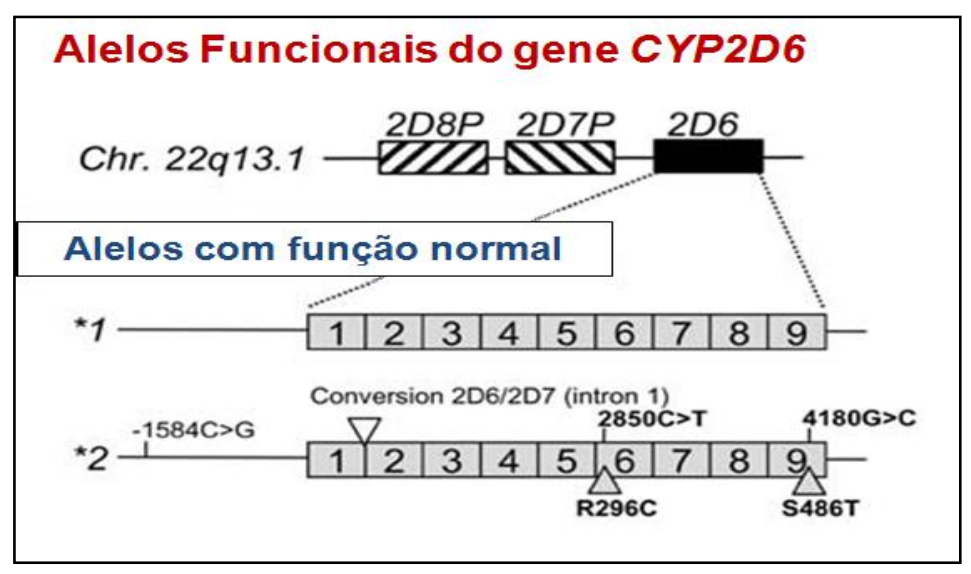

Figura 6. Esquema do gene CYP2D6*1 (selvagem) e o alelo *2. Observam-se as substituições de Arginina por Cisteína (R296C) e Serina por Treonina.

Fonte: Figura adaptada de Zanger, 2004 


\subsection{Fenotipagem}

O procedimento mais comum de fenotipagem é a determinação do índice metabólico (MR do inglês Metabolic Ratio), que é o índice das quantidades do fármaco inalterado e o metabólito fármaco que aparece na urina durante um intervalo de tempo, após a administração de uma única dose da substância teste ${ }^{37}$. Em estudos de populacionais, o MR é uma medição sensível de polimorfismos, que é baseado de maneira inversa a sua depuração plasmática (ou clearance, em inglês), demonstrado por considerações teóricas por Jackson e outros ${ }^{51}$.

A determinação do fenótipo do gene CYP2D6 foi amplamente estudada em farmacogenética clínica. Os fármacos debrisoquina, esparteína, metoprolol e dextrometorfano (DM), entre outros, têm sido usados tradicionalmente como substância teste ou probe para medir a atividade da CYP2D6 in vivo e in vitro. DM [D-(+)-3-methoxy-17-methyl$(9 \alpha, 13 \alpha, 14 \alpha)$-morphinan] é um antitussígeno não-narcótico de ação central, administrado por via oral e amplamente prescrito como hidrobrometo de DM. O DM está estruturalmente relacionado ao opióide morfínico levorfanol, possui sítios de ligação no Sistema Nervoso Central tais como os receptores N-metil-D-aspartato e os receptores sigma. Na clínica médica, ele é usado para atenuar a tolerância analgésica produzida pela substância morfina, pois não causa dependência. Este fármaco é metabolizado em seu metabólito ativo dextrorfano (DX), portanto este fármaco é um pró-fármaco ${ }^{10}$. Ele é bem absorvido pelo sistema digestivo e não se liga às proteínas plasmáticas. Seus efeitos adversos do DM são muito raros e sua toxicidade é muito baixa. Dado que a debrisoquina e a esparteína estão disponíveis somente em um número limitado de mercados e algumas vezes eles causam efeitos colaterais, o DM parece ser a substância de escolha que muitos laboratórios utilizam como substância teste para determinar o fenótipo do $C Y P 2 D 6^{52}$.

Embora as concentrações dos compostos parentais e dos metabólitos podem ser determinadas em diferentes fluídos biológicos (por exemplo, plasma e saliva), seu índice metabólico (DM/DX) na urina é o método mais freqüentemente usado para avaliar o metabolismo da CYP2D6 in vivo. Alguns estudos sugerem que existe uma boa correlação nos resultados da medição do índice metabólico nestes diferentes tecidos ${ }^{53}$. Em um estudo mais recente foi levantada a hipótese que as proporções metabólicas urinárias não refletiriam o clearance oral do $\mathrm{DM}^{54}$. Desta maneira, a razão metabólica urinária DM/DX é rotineiramente 
aplicada para segregar as populações em dois grupos principais de fenótipos: Completos (EM do inglês Extensive Metabolizer) e Lentos ${ }^{46}$ (PM do inglês Poor Metabolizer). É consenso o uso do anti-modal com valor de 0.3, que é o ponto de corte entre EMs e PMs. Valores maiores ou iguais a 0.3 são característicos de pessoas com fenótipo PM, valores menores de 0.3 consideram-se como fenótipo EM. A razão DM/DX pode ser medida na urina pelos métodos de Cromatografia Líquida de Alta Eficiência (HPLC, do inglês High Performance/Pressure Liquid Chromatography), Cromatografia de Gás Líquido/Sólido (GC), entre outros ${ }^{55,56}$.

A principal enzima que catalisa a $O$-desmetilação do dextrometorfano é a CYP2D $6^{57}$, gerando seu principal metabólito o $\mathrm{DX}^{55,58}$. Mas esta via não é a única, existe outra via de metabolismo do DM, mediado por CYP3A3/4, CYP3A5, CYP2A7, CYP2C9 e CYP2C19. Todas elas catalisam a biotransformação de DM a 3-metoximorfina (MM) que é um composto inativo, via $N$-desmetilação. Ambas a DX e a MM são desmetiladas a 3-hidroximorfina (HM) a qual é excretada na urina, principalmente conjugado com glicuronídeo ${ }^{21,52,53}$, isto é mostrado na Figura 7.

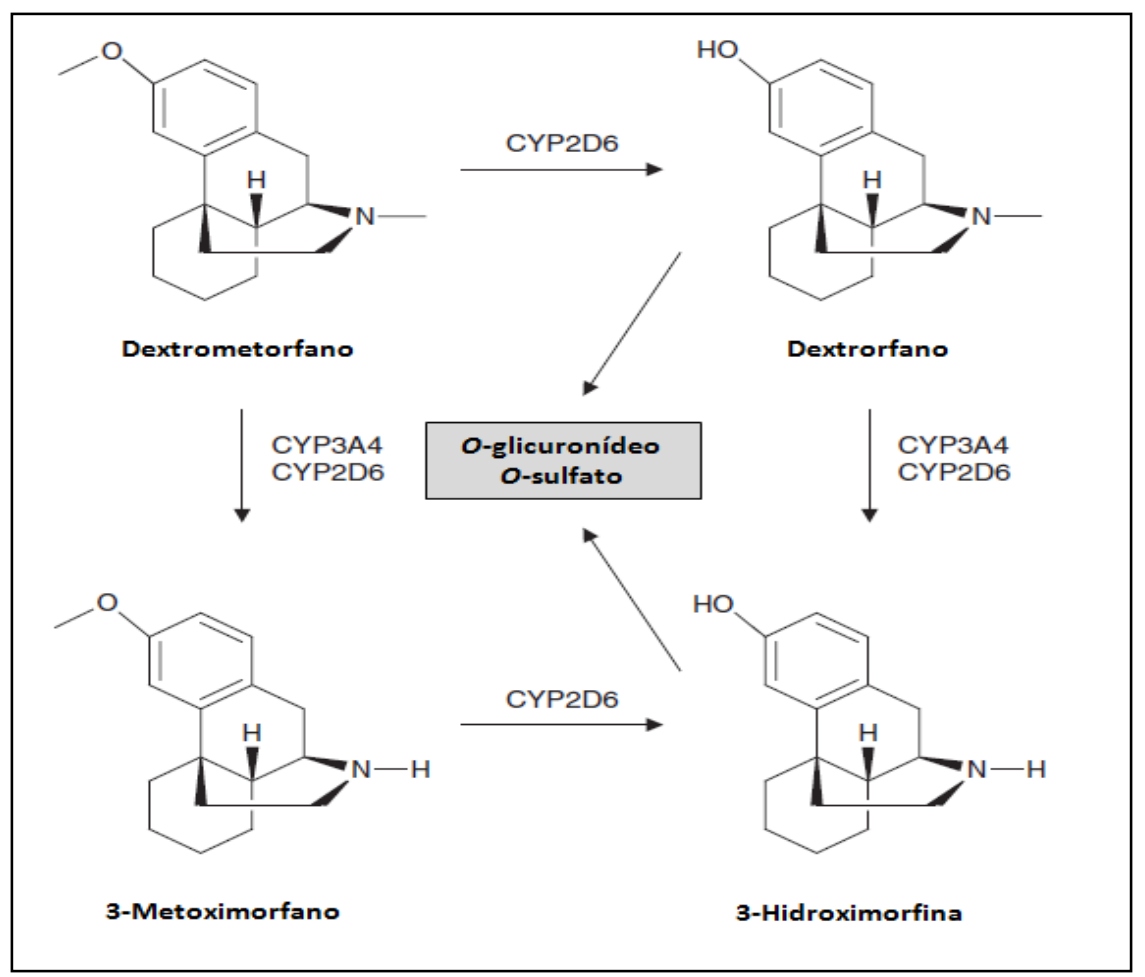

Figura 7. Metabolismo de dextrometorfano pela CYP2D6. A formação de dextrorfano a partir de dextrometorfano é principalmente mediada pela CYP2D6 via $O$-desmetilação. As reações por $N$-desmetilação são mediadas principalmente pela enzima CYP3A4.

Fonte: Adaptado de Zhou, 2009. 


\subsubsection{Farmacocinética}

Após a administração oral, o DM é absorvido rapidamente, entrando na circulação sangüínea e atravessando a barreira hematoencefálica. O fármaco DM é metabolizado por várias enzimas do fígado e, em seguida, processado através de $O$-demetilação (responsável pela produção do DX), de $N$-desmetilação, e de conjugação parcial com ácido glicurônico e íons sulfato ${ }^{21,52,53}$.

A primeira passagem através da veia porta hepática resulta na metabolização do DM em DX, o derivado 3-hidroximorfina, através da enzima CYP2D6. Algumas horas após a terapia com DM em seres humanos, os metabólitos 3-hidroxi-N-metilmorfina e 3-morfina, assim como os traços da droga inalterada DM, são detectáveis na urina ${ }^{52,53}$.

\subsubsection{Farmacodinâmica}

Em doses terapêuticas, o DM possui ação central, elevando o ponto inicial da tosse, sem inibir a atividade ciliar. O DM é absorvido rapidamente e inicia sua atividade entre 15 e 60 minutos após a ingestão. A duração da ação após a administração oral é de 3 a 8 horas. A dosagem média necessária para uma terapia eficaz desse antitussígeno é de $10 \mathrm{mg}$ a $30 \mathrm{mg}$ a cada 4 ou 6 hs $^{10}$.

\subsubsection{Bioequivalência}

A bioequivalência se refere à comparação da biodisponibilidade de dois fármacos de origem diferentes, ou seja, como estes se comportam no organismo em termos de disponibilidade para exercer sua ação terapêutica. São considerados bioequivalentes quando são semelhantes para ambos os parâmetros Concentração plasmática Máxima e Tempo para alcançar a Concentração Máxima no plasma e as respectivas áreas sob a curva de concentração plasmática versus tempo são equiparáveis.

Algumas questões de bioinequivalência têm sido observadas entre fármacos, justificando a importância dos estudos comparativos de diferentes preparações quanto à biodisponibilidade, a fim de garantir ao paciente equivalência terapêutica entre os diferentes 
medicamentos comercializados, principalmente quando se trata de terapias de risco, onde as substituições entre formulações podem resultar em graves problemas.

A continuação descrevem-se os parâmetros mais usados para a determinação da bioequivalência entre fármacos:

\subsubsection{Concentração plasmática máxima (Cmáx)}

A Cmax representa a maior concentração plasmática atingida pelo fármaco após a administração oral, ela é diretamente proporcional à absorção. Portanto, depende diretamente da extensão, da velocidade de absorção e da velocidade de eliminação. Para um efeito terapêutico ótimo e seguro, esse parâmetro deve estar posicionado, sobre a curva de concentração sangüínea versus tempo, entre a concentração mínima efetiva e a concentração máxima tolerada 9 .

\subsubsection{Tempo para alcançar a concentração máxima no plasma (Tmáx)}

A Tmáx tem apresenta relação estreita com a velocidade de absorção do fármaco e pode ser usado como simples medida da absorção. É alcançada quando a velocidade de entrada do fármaco na circulação é excedida pelas velocidades de eliminação e distribuição?

\subsubsection{3 Área sob a curva de concentração plasmática versus tempo (AUC)}

A AUC indica a quantidade total de fármaco absorvido. Para fármacos administrados cronicamente, é um parâmetro mais crítico do que a velocidade de absorção. É considerado o parâmetro mais importante na avaliação da biodisponibilidade, sendo expresso em quantidade/volume versus tempo $(\mathrm{mgh} / \mathrm{mL})$ e é representativo da quantidade total de fármaco absorvido após administração de uma dose única da substância ativa. A AUC é proporcional à quantidade de fármaco que entra na circulação sistêmica e independe da velocidade ${ }^{9}$. 


\subsection{Reação Adversa a Fármacos}

Os diversos fenótipos foram correlacionados com a presença das denominadas reações adversas a fármacos (ADR, do inglês Adverse Drugs Reaction) que na linguagem coloquial são chamados de alergias a fármacos. A literatura revela vários casos em pacientes não relacionados e descrevem a ocorrência de ADR na presença de polimorfismo. Um estudo de revisão de casos de ADR reportados nos Estados Unidos, cujo objetivo foi avaliar o papel potencial da farmacogenômica na diminuição de incidências de ADR. O estudo sugere que a terapia farmacológica personalizada pode causar uma importante diminuição nos casos de $\mathrm{ADR}^{5}$. As enzimas CYP1A2 e CYP2D6 que metabolizam 5\% e 25\% respectivamente de todas as drogas prescritas e estas foram relacionadas com o metabolismo de $75 \%$ e $38 \%$ das drogas $\mathrm{ADR}^{59}$. Isto sugere que a alteração da dose de um determinado fármaco administrado a um paciente previamente genotipado pode prevenir a ocorrência de ADR. Unicamente 20\% das drogas que são substratos para enzimas não polimórficas são reportadas como ADR. Foi estimado que: ADR custa à sociedade americana aproximadamente US\$ 100 bilhões, causando mais de cem mil mortes anualmente nos Estados Unidos, atingindo até um 7\% das admissões hospitalares no Reino Unido e Suécia por causa de ADR ${ }^{17}$. 
2 JUSTIFICATIVA 
A literatura ressalta o estudo, análise e caracterização dos polimorfismos de enzimas que metabolizam fármacos e sua importância devido a diversas razões. Uma delas aborda o sucesso de um tratamento, que se correlaciona diretamente com o perfil genético da população. Não todas as pessoas de uma mesma população respondem de maneira similar a um determinado fármaco, e isto gera um problema social e econômico, seja para o paciente quanto para o governo, pois se investem enormes quantidades de dinheiro em tratamentos que muito provavelmente ou terão um efeito não tão bem sucedido ou sem o efeito desejado e só poucas vezes bem sucedido. Estes fatos sustentam a necessidade do estudo do perfil farmacogenético a grande escala na população, mesmo por se tratar de uma população muito miscigenada. O sistema de saúde ainda está longe de poder brindar, de maneira rotineira, testes que confirmem os perfis farmacogenéticos para a população, fato que não ocasionará um tratamento farmacológico mais personalizado, que é um dos objetivos principais da Farmacogenética.

Atualmente existem poucos trabalhos no país que possam indicar com clareza os perfis de polimorfismos d e alguns genes da CYP450 na população. O problema fica agravado em nosso país, de tamanho continental, onde a miscigenação aconteceu em todas as regiões geográficas com grupos populacionais diversos. Como foi explicado, existem características polimórficas associadas a grupos étnicos no planeta todo e os imigrantes vieram com essas características genéticas. Portanto, no país que já abrigou grandes migrações ao longo da nossa história e que, ainda, continua abrigando, é preciso criar as condições para poder obter esses dados que serão de muita utilidade para as políticas de saúde pública e para o conforto do cidadão com a diminuição das reações adversas a fármacos e melhor tratamento. Este trabalho está plenamente justificado pelos enunciados anteriores.

Este trabalho visa à obtenção de um perfil genotípico e fenotípico mais geral de uma amostra populacional pequena na região de Campinas. A elegância do trabalho fica por conta da comparação dos dados fenotípicos e os genotípicos, fato que não é muito comum no país. 
3 OBJETIVOS 


\subsection{Objetivo Geral}

Avaliar os polimorfismos mais freqüentes do gene CYP2D6 utilizando como substância teste o fármaco Dextrometorfano em voluntários sadios da região de Campinas SP.

\subsection{Objetivos Específicos}

1. Determinar os alelos polimórficos CYP2D6*1 (selvagem), CYP2D6*3, $C Y P 2 D 6 * 4, C Y P 2 D 6 * 5$ e $C Y P 2 D 6 * 6$ pelo método de genotipagem usando a técnica Tetra Primer Multiplex Long PCR (24) em voluntários sadios usando como substância probe o fármaco DM.

2. Avaliar a influência dos alelos identificados correlacionando com as propriedades farmacocinéticas do fármaco DM e realizar a comparação dos fenótipos pela genotipagem e fenotipagem.

3. Avaliar a frequiência genotípica dos alelos $C Y P 2 D 6 * 1, * 2, * 3, * 4, * 5, * 6, * 10$, *17 e *41 em voluntários sadios, pelo método de seqüenciamento.

4. Analisar pelo método de Real Time PCR o número de cópias do gene CYP2D6 em todas as amostras de DNA. 
4 MATERIAL E MÉTODOS 


\subsection{Voluntários}

Setenta e oito voluntários sadios com idade de 19 a 47 anos (média \pm Desvio Padrão DP: 30,61 $\pm 7,64$ ), com altura média de 1,67 $\pm 0,09 \mathrm{~m}$ e um peso médio de $66.46 \pm 9,91 \mathrm{~kg}$, foram compreendidos no estudo. Todos eles assinaram o termo de consentimento livre e esclarecido, foi informado sobre o estudo (ANEXO A). Os voluntários não tiveram histórico recente de medicação durante os últimos 7 dias antes do estudo, nem tampouco histórico de abuso de drogas ou uso de tabaco; todos eles tiveram diagnóstico negativo para hepatite $\mathrm{B}, \mathrm{C}$ e HIV, e tiveram também diagnósticos negativos de doenças cardíacas, hepáticas, renais, pulmonares, neurológicas, gastrintestinais e hematológicas, e foram avaliados por médicos e por exames laboratoriais.

\subsection{Fármaco teste}

O fármaco usado neste estudo foi Dextrometorfano (Dextromethorphan WallTussin). Cada 5mL contém $10 \mathrm{mg}$ de DM e 100 mg de guaifenesina (Lote 4JK0029, data de expiração de 07/2006) de Wallgreen Co., Deerfield, IL. USA).

\subsection{Comitê de Ética em Pesquisa envolvendo seres humanos}

O projeto de pesquisa foi submetido ao Comitê de Ética em Pesquisa da UNICAMP, o qual aprovou o estudo com o parecer No. 005/2005. Posteriormente, foi submetido à Comissão de Ética em Pesquisas com Seres Humanos do ICB - USP, o qual convalidou o projeto com o parecer No. 831/CEP.

\subsection{Fase clínica de Internação}

Os voluntários foram internados um dia antes da administração do fármaco, entre as $5.00 \mathrm{~h}$ e $21.00 \mathrm{~h}$. Uma vez internados todos os voluntários receberam alimentação $8 \mathrm{~h}$ antes da administração do fármaco, e no intervalo de tempo máximo de duas horas para a ingestão de água.

Os voluntários não receberam outro tipo de alimento que não seja o padronizado durante todo o tempo de internamento e o único líquido permitido para beber era a água. Os 
voluntários receberam uma dose de $15 \mathrm{~mL}$ de WallTussin DM o qual foi ingerido com 200 $\mathrm{mL}$ de água. A coleta das amostras de sangue (para genotipagem de uma única vez e para fenotipagem com diferentes intervalos) começou logo após da primeira administração e nos seguintes intervalos de tempos: $0.5,0.75,1,1.5,2,2.5,3,3.5,4,6,8,12,16,24,36,48,72$, 120 e 168 horas depois de uma única administração; a coleta de urina se iniciou antes da administração da dose. Ao final da internação, após 24 horas, permitiu-se a saída dos voluntários e eles foram requeridos para retornar ao centro médico nas próximas 36, 48, 72, 120 e 168 horas para a coleta de sangue após a administração. Na última coleta (168h) um médico avaliou a saúde dos voluntários.

\subsection{Fenotipagem}

\subsubsection{Análise através de HPLC/LC-MS-MS}

Os ensaios de quantificação da droga DM e de seu metabólito DX na urina foram realizados por Cromatografia Líquida de Alta Eficiência (HPLC) acoplada ao tandem Espectrometria de Massa (LC-MS-MS) para possibilitar a caracterização fenotípica de cada voluntário. As amostras de urina foram coletadas em dois momentos distintos: imediatamente após e 12 horas após a administração do xarope DM.

\subsubsection{Quantificação das Amostras}

As concentrações de DM e de DX de urina foram quantificadas através de HPLC-LCMS-MS usando como Padrão Interno (PI) as seguintes moléculas Dextrometorfano-D3 (DMD3) e Dextrorfano-D4 (DX-D4).

\subsubsection{Preparação das Curvas de Calibração}

A curva de calibração consistiu de um branco (matriz processada sem o PI); de uma amostra de urina denominada zero (matriz processada com o PI); e das amostras de urina padrões a serem quantificadas.

As amostras de urina padrões foram preparadas adicionando as soluções padrões de trabalho contendo o analito a ser quantificado (droga mãe DM ou seu metabólito DX) às amostras controles de urina humana (Tabela 1). 


\subsubsection{Preparação dos Controles de Qualidade (QC)}

As amostras dos controles de qualidade (QC) foram preparadas adicionando-se as soluções padrões contendo o analito a ser quantificado (DM ou DX) às amostras controles de urina humana (Tabela 2). Foram utilizados 3 controles de qualidade diferentes.

\subsubsection{Validação da Corrida Analítica}

A corrida analítica consiste na curva de calibração, QCs e quantificação do analito (DM ou DX) nas amostras coletadas. O coeficiente de variação máximo permitido para os QCs foi de $15 \%$, podendo haver 2 rejeições por corrida analítica, desde que não seja na mesma concentração. Para o Limite de Quantificação (LOQ), o coeficiente de variação máximo permitido foi de $5 \mathrm{ng} / \mathrm{mL}$. Para a curva de calibração, pelo menos 5 das 8 concentrações deveriam apresentar coeficiente de variação de, no máximo, $15 \%$, desde que não correspondessem a menor e / ou maior concentração. Para a menor concentração da curva de calibração, o coeficiente de variação não pôde exceder $20 \%$. O coeficiente de linearidade da curva foi de, no mínimo, $95 \%$.

Tabela 1 - Preparação das curvas de calibração para a análise das amostras de urina através de experimentos de fenotipagem

\begin{tabular}{lcccccc}
\hline Analito & $\begin{array}{c}\text { Curva de } \\
\text { Calibração } \\
\text { (concentração } \\
\text { na urina) } \\
(\mathbf{n g} / \mathbf{m L})\end{array}$ & $\begin{array}{c}\text { Volume }(\mathbf{m L}) \mathbf{e} \\
\text { Concentração } \\
(\mathbf{n g} / \mathbf{m L})\end{array}$ & $\begin{array}{c}\text { Volume } \\
(\mathbf{m L}) \\
\text { de Urina }\end{array}$ & $\begin{array}{c}\text { Volume } \\
\text { Total } \\
(\mathbf{m L})\end{array}$ & $\begin{array}{c}\text { Fator } \\
\text { de } \\
\text { Diluição }\end{array}$ \\
\hline DM ou DX & 5 & 1,0 & 50 & 9,0 & 10,0 & 10 \\
DM ou DX & 10 & 1,0 & 100 & 9,0 & 10,0 & 10 \\
DM ou DX & 20 & 1,0 & 200 & 9,0 & 10,0 & 10 \\
DM ou DX & 50 & 1,0 & 500 & 9,0 & 10,0 & 10 \\
DM ou DX & 100 & 1,0 & 1000 & 9,0 & 10,0 & 10 \\
DM ou DX & 200 & 1,0 & 2000 & 9,0 & 10,0 & 10 \\
DM ou DX & 500 & 1,0 & 5000 & 9,0 & 10,0 & 10 \\
DM ou DX & 1000 & 1,0 & 10000 & 9,0 & 10,0 & 10 \\
Zero & 0 & 1,0 & ---- & --- & --- & --- \\
Branco & 0 & 1,0 & ---- & --- & --- & --- \\
\hline
\end{tabular}


Tabela 2 - Preparação das amostras dos controles de qualidade usadas na quantificação de DM ou de DX

\begin{tabular}{|c|c|c|c|c|c|c|}
\hline $\mathbf{Q C}$ & $\begin{array}{c}\text { Controle de } \\
\text { Qualidade } \\
\text { (concentração no } \\
\text { plasma) } \\
(\mathbf{n g} / \mathbf{m L})\end{array}$ & $\begin{array}{r}\text { Volu } \\
\text { Con } \\
(1 \\
\text { da Solu }\end{array}$ & $\begin{array}{l}\text { L) e } \\
\text { ação } \\
\text { rabalho }\end{array}$ & $\begin{array}{c}\text { Volume } \\
\text { de Plasma } \\
\text { Controle } \\
\text { Adicionado } \\
(\mathbf{m L})\end{array}$ & $\begin{array}{c}\text { Volume } \\
\text { Total } \\
(\mathrm{mL})\end{array}$ & $\begin{array}{c}\text { Fator } \\
\text { de } \\
\text { Diluição }\end{array}$ \\
\hline$\overline{\text { QCA }}$ & 15 & 1,0 & 150 & 9,0 & 10,0 & 10 \\
\hline QCB & 150 & 1,0 & 1500 & 9,0 & 10,0 & 10 \\
\hline QCC & 750 & 1,0 & 7500 & 9,0 & 10,0 & 10 \\
\hline
\end{tabular}

\subsubsection{Preparação das Amostras}

Inicialmente, um volume de $200 \mu \mathrm{L}$ de amostra de urina foi preparada adicionando-se $50 \mu \mathrm{L}$ de uma solução contendo PI, a fim de obter uma concentração final de $1 \mu \mathrm{g} / \mathrm{mL}$ de PI. Então, $200 \mu \mathrm{L}$ de tampão carbonato / bicarbonato $(\mathrm{pH} 8,5)$ foram adicionados. As amostras foram misturadas, adicionando-se $4 \mathrm{~mL}$ da solução éter etílico / diclorometano. Após homogeneização, seguida de agitação vigorosa, a fase orgânica (superior) foi transferida para um novo tubo e seca, usando-se um fluxo de nitrogênio. Um volume de $200 \mu \mathrm{L}$ de solução aquosa de acetonitrila e $12 \mathrm{mM}$ de ácido fórmico foi adicionado à amostra seca para a reconstituição da mesma. Essa solução preparada foi homogeneizada e transferida para vials a fim de possibilitar a sua leitura.

\subsubsection{Sistema HPLC / LC-MS-MS}

Um volume de $10 \mu \mathrm{L}$ de cada amostra preparada foi injetado no sistema HPLC/LCMS-MS (quatro LC, Micromass - UK) ajustado com uma bomba de 4 pólos (G1311A, Agillent-USA) e com um eletrospray positivo (ES+), usando um sistema de monitoramento de reações múltiplas (MRM) e uma solução de fase móvel fluindo no sistema a $1 \mathrm{~mL}$ por min. Utilizou-se uma coluna cromatográfica C8 $3 \mu \mathrm{m}$ (100 x 4,6 mm, Prevail, Alltech, USA).

\subsubsection{Métodos Fenotípicos}

As amostras de urina foram coletadas imediatamente antes da administração da dose de 30 mg de DM e até as 12 horas seguidas do ensaio de quantificação e para caracterização 
da fenotipagem. As amostras foram acidificadas com ácido ascórbico e mantidas a temperatura de $-80^{\circ} \mathrm{C}$ à espera da fase analítica.

\subsection{9 Índice Metabólico de Biotransformação}

De acordo a publicações prévias ${ }^{55}$, as proporções de concentrações DM/DX foram calculadas para todos os voluntários. Resultados iguais ou maiores do que 0,3 foram considerados por serem fenótipos PM e os resultados menores do que 0,3 foram considerados por serem fenótipos EM.

\subsection{Genotipagem}

Foram estudadas 75 amostras de DNA de sangue periférico de voluntários recrutados pela Unidade Analítica Cartesius (São Paulo) e pela Unidade de Pesquisa Galeno (Campinas).

4.6.1 Genotipagem dos alelos $C Y P 2 D 6 * 1, * 3, * 4, * 6$ pelo método de Tetra Primer e alelo CYP2D6*5 pelo método Long PCR

\subsubsection{Extração de DNA}

A extração do DNA genômico foi realizada a partir de $4 \mathrm{~mL}$ de sangue venoso coletado em tubos PAXgene Blood DNA Tubes (Qiagen), seguindo o protocolo 2 do Kit "Easy DNA" (Invitrogen). O DNA foi ressuspendido em tampão TE [Tris $\mathrm{HCl} 10 \mathrm{mM}$, EDTA $1 \mathrm{mM}, \mathrm{pH}$ 8.0]. O DNA foi armazenado à $-20^{\circ} \mathrm{C}$. O cálculo da concentração de DNA extraído foi realizada por espectrofotometria $(\lambda=260 \mathrm{~nm})$ utilizando o espectrofotômetro UV Mini 1240 (Shimadzu).

\subsubsection{Primers}

Os primers foram sintetizados pela empresa Integrated DNA Technologies - IDT (Coralville, IA, USA), sendo as seqüências de bases nitrogenadas descritas por Hersberger (Hersberger et al., 2000) 
4.6.4 Genotipagem dos alelos $C Y P 2 D 6 * 1, * 3, * 4, * 5$ e *6

A escolha dos alelos $* 3, * 4, * 5 e * 6$ foi pela sua característica fenotípica por serem não funcionais. A análise de genotipagem do $C Y P 2 D 6 * 3$, *4 $e * 6$ foi feita pelo método de PCR tetra primer ${ }^{42}$ e do alelo 5 será realizada por multiplex long $\mathrm{PCR}^{43}$. Os primers foram sintetizados pela IDT (Integrated DNA Technologies). As seqüências dos primers específicos para cada alelo estão representadas na Tabela 3.

Tabela 3 - Lista de Primers usados no método Tetra Primer. * Os primers em negrita são específicos para as variantes alélicas

\begin{tabular}{lc}
\hline Primers & Seqüências \\
\hline 1 new & TCCCAGCTGGAATCCGGTGTCG \\
2 new & GGAGCTCGCCCTGCAGAGACTCCT \\
3 & GCGGAGCGAGAGACCGAGGA \\
4 new & GGTCCGGCCCTGACACTCCTTCT \\
6 & GCTAACTGAGCACG* \\
7 & CGAAAGGGGCGTCC* \\
11 & TCCTCGGTCACCCA* \\
Awt & TCCCAGGTCATCCT* \\
Bmut & TCTCCCACCCCCAA* \\
Tmut & GTCGCTGGAGCAGG* \\
Dlow & CAGGCATGAGCTAAGGCACCCAGAC \\
Dup & CACACCGGGCACCTGTACTCCTCA \\
DPKup & GTTATCCCAGAAGGCTTTGCAGGCTTCA \\
DPKlow & GCCGACTGAGCCCTGGGAGGTAGGTA \\
\hline
\end{tabular}

FONTE: Hersberger, 2000

4.6.5 Condições da PCR para os alelos CYP2D6*1, *3, *4 e*6

A PCR foi feita no termociclador TC-412 FlexiGene (Techene®, Cambridge, UK). Para detecção dos alelos *3,*4 e*6 foram preparados $25 \mu \mathrm{L}$ de reação de tetra-primer PCR. Na mistura são utilizados Tris-HCl 10 mM, pH 8,3, KCl 25 mM, MgCl2 $1.5 \mathrm{mM}, 1 \mathrm{U}$ PlatinumR Taq DNA Polymerase (Invitrogen), 0,2 mM/L de dNTP e cerca de $200 \mathrm{ng}$ de DNA genômico. 
Os primers usados para a análise do Alelo *3 foram: Primer 3, 4new, Primer 6 e Awt. Como a reação utiliza 4 primers, elas vão gerar 2 bandas (se for homozigoto) ou 3 bandas (se for heterozigoto), a maior de 1106pb que é o controle da reação, amplificado pelo uso dos primers Primer3 e 4 new. Duas bandas são geradas, uma de $580 \mathrm{pb}$ e outra de $553 \mathrm{pb}$, ambas pelo uso dos primers Primer 6 e Awt em combinação com os primers Primer3 e 4 new. As concentrações dos primers para a PCR foram: 0,75 nM dos primers 3 e 4 new e $75 \mathrm{nM}$ dos primers 6 e Awt.

As condições de ciclagem para $C Y P 2 D 6^{*} 3$ foram: $94^{\circ} \mathrm{C}$ por $10 \mathrm{~min}, 20$ ciclos de $94^{\circ} \mathrm{C}$ por $30 \mathrm{~s}, 63^{\circ} \mathrm{C}$ por $30 \mathrm{~s} \mathrm{e} 72^{\circ} \mathrm{C}$ por $60 \mathrm{~s}$, e uma segunda ciclagem de 27 ciclos de $94^{\circ} \mathrm{C}$ por 30 $\mathrm{s}, 53^{\circ} \mathrm{C}$ por $30 \mathrm{~s} \mathrm{e} 72^{\circ} \mathrm{C}$ por $60 \mathrm{~s}$ e na etapa final $72^{\circ} \mathrm{C}$ por $7 \mathrm{~min}$.

Os primers usados para a análise do Alelo *4 foram: 1new, Bmut, Primer 7 e 2 new. Do mesmo modo, como a reação utiliza 4 primers, elas vão gerar 2 bandas (se for homozigoto) ou 3 bandas (se for heterozigoto), a maior de 750pb que é o controle da reação, amplificado pelo uso dos primers 1new e 2 new. Duas bandas são geradas, uma de 580pb e outra de 553pb, ambas pelo uso dos primers Bmut e Primer 7 em combinação com os primers Primer3 e 4 new. As concentrações dos primers para a PCR foram: 1,25 nM dos primers 1new e 2new, $75 \mathrm{nM}$ do Bmut e $50 \mathrm{nM}$ do primer 7.

Os primers usados para a análise do Alelo *6 foram: 1new, Tmut, Primer 11 e 2 new. A reação utiliza 4 primers, elas vão gerar 2 bandas (se for homozigoto) ou 3 bandas (se for heterozigoto), a maior de 750pb que é o controle da reação, amplificado pelo uso dos primers 1 new e 2 new. Duas bandas são geradas, uma de $421 \mathrm{pb}$ e outra de $356 \mathrm{pb}$, ambas pelo uso dos primers Tmut e Primer 11 em combinação com os primers 1new e 2new. As concentrações para a PCR foram: 1,25 $\mathrm{nM}$ dos primers 1 new e 2 new e $75 \mathrm{nM}$ dos primers Tmut e11.

As condições de ciclagem para os alelos $* 4$ e $* 6$ foram: $94^{\circ} \mathrm{C}$ por $10 \mathrm{~min}, 15$ ciclos de $94^{\circ} \mathrm{C}$ por $30 \mathrm{~s}, 63^{\circ} \mathrm{C}$ por $30 \mathrm{~s} \mathrm{e} 72^{\circ} \mathrm{C}$ por $60 \mathrm{~s}, 27$ ciclos de $94^{\circ} \mathrm{C}$ por $30 \mathrm{~s}, 53^{\circ} \mathrm{C}$ por $30 \mathrm{~s} \mathrm{e} 72^{\circ} \mathrm{C}$ por $60 \mathrm{~s}$ e por final $72^{\circ} \mathrm{C}$ por $7 \mathrm{~min}$.

Os produtos de PCR dos alelos *3, *4 e *6 são separados por eletroforese em gel de agarose $2 \%$, na presença de marcador molecular. A visualização é feita em luz ultravioleta, 
através de coloração com brometo do etídio. A imagem será capturada e analisada pelo Programa "Eagle Eye II - Stratagene".

\subsubsection{Condições das Reações da PCR do alelo CYP2D6*5}

Foi feita uma reação de Long $P C R$ de $50 \mu \mathrm{L}$. Na mistura da reação foram usados 36.1 $\mu \mathrm{L}$ de água, $5 \mu \mathrm{L}$ de tampão $(2.25 \mathrm{mmol} / \mathrm{L} \mathrm{MgCl}), 0.75 \mu \mathrm{L}$ PlatinumR Taq DNA Polymerase (3.5U), $1.75 \mu \mathrm{L}$ de dNTPs (mistura de $10 \mathrm{mmol} / \mathrm{L}$ ), $0.4 \mu \mathrm{L}$ de primer Dlow, 0.8 $\mu \mathrm{L}$ de primer DPKup, $0.8 \mu \mathrm{L}$ de primer DPKlow e $4.0 \mu \mathrm{L}$ de DNA genômico (aproximadamente $50 \mathrm{ng} / \mu \mathrm{L}$ ).

As condições de ciclagem foram: 1 min a $94{ }^{\circ} \mathrm{C}$, seguido de 35 ciclos de $94{ }^{\circ} \mathrm{C}$ por $60 \mathrm{~s}$, $65^{\circ} \mathrm{C}$ por $30 \mathrm{~s}, 68^{\circ} \mathrm{C}$ por $5 \mathrm{~m}$, e uma extensão final de $7 \mathrm{~m}$ a $68^{\circ} \mathrm{C}$.

Os primers usados para a análise do Alelo *5 foram: Dup e Dlow (produto de amplificação de $3.2 \mathrm{~kb}$ ). Este produto de amplificação indica a deleção de gene CYP2D6. DPKup e DPKlow (produto de amplificação de $5.1 \mathrm{~kb}$ ). Este produto de amplificação indica os alelos selvagens do gene $C Y P 2 D 6^{60}$.

Os produtos de PCR do alelo *5 são separados por eletroforese em gel de agarose 1\%, na presença de marcador molecular. A visualização é feita em luz ultravioleta, através de coloração com brometo do etídio. A imagem foi capturada e analisada pelo Programa "Eagle Eye II - Stratagene". A explicação do método Tetra-Primer se ilustra na Figura 8.

\subsubsection{Etapa Clínica}

Os voluntários novamente selecionados através dos experimentos de fenotipagem foram internados no dia anterior à administração do fármaco, entre $17 \mathrm{~h}$ e $20 \mathrm{~h}$. Uma vez confinados, todos os voluntários ficaram em jejum alimentar por um período de, no mínimo, 8 horas antes da administração da droga. A ingestão de líquidos foi permitida até 6 horas antes e 2 horas após essa administração. A dieta, tanto de alimentos quanto de líquidos, obedeceu ao mesmo padrão para todos os voluntários, ela foi isenta de substâncias xantínicas, como café, chá-preto e bebidas contendo cola. 
A administração consistiu em uma única dose de $15 \mathrm{~mL}$ do xarope Walltussin Dextrometorfano (30 mg de DM) ingerido com $30 \mathrm{ml}$ de água sem gás.

Para possibilitar a realização dos experimentos de farmacocinética, amostras de sangue foram colhidas imediatamente após a administração e nos seguintes tempos: 30 min; 1,0 h; 1h30 min; 2h; 2h30min; 3h; 3h30min; 4,0 h; 6,0 h; 8,0 h; 12,0 h; 16,0 h; 24,0 h; 36,0 h; 48,0 h; 72,0 h; 120,0 h; e 168,0 h após a administração da droga.

No decorrer do confinamento, os voluntários receberam 2 refeições: uma após 4 horas e outra entre 7 e 8 horas após a administração do fármaco.

Após 24 horas de "internação", foi permitido aos voluntários um regime aberto, retornando para coletas de amostras de sangue nos seguintes tempos pós-administração da droga: 36,0; 48,0; 72,0; 120,0; e 168,0 horas.

Após a última coleta da amostra de sangue, os voluntários realizaram exames clínicos (incluindo registro de eletrocardiograma) para a verificação de suas condições físicas.

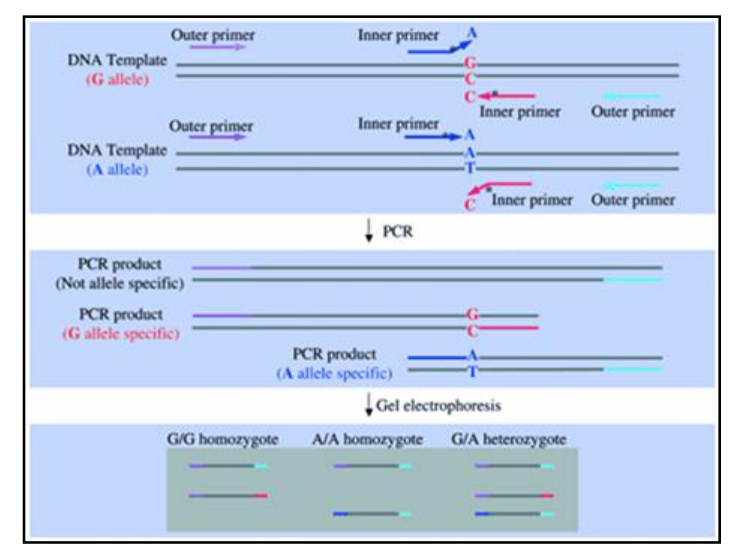

Figura 8. Esquema das reações de PCR pelo método Tetra Primer para os alelos *3, *4 e *6. O uso de quatro primers, sendo 2 controles específicos do gene CYP2D6 e outros 2 específicos para a deteção da variante alélica. Quando a amostra de DNA apresentar alelos homozigotos da variante alélica, a reação vai amplificar 2 bandas, sendo a de maior peso molecular o controle do gene e a de menor peso da variante alélica. Se a mostra for de heterozigoto, encontraremos 3 bandas, sendo a de maior peso do gene controle e as outras dos respectivos alelos. Outer primer são os primers controle do gene, e Inner Primer da variante alélica. Fonte: Ye, 2001. 
4.6.8 Genotipagem dos alelos $* 1, * 2, * 3, * 4, * 5, * 10, * 17$ e *41, pelo método de Seqüenciamento

A genotipagem pelo método de seqüenciamento foi realizada no Laboratório LIM27 da Profa. Dra. Elida Benquique Ojopi da Faculdade de Medicina da USP, Departamento de Psiquiatria. Este método foi desenvolvido e padronizado como parte do trabalho de mestrado da aluna Carolina Martins do Prado.

As 75 amostras de DNA dos voluntários foram seqüenciadas. Somente 19 amostras tiveram condições para serem avaliadas por este método. As amostras restantes apresentaram DNA degradado.

\subsubsection{Escolha das regiões dos primers}

O desenho dos primers foi feito a partir das informações que se encontram no site da Human Cytochrome P450 (CYP) Allele Nomenclature Committee ${ }^{61}$, onde são indicados os locais onde se encintam as mutações pontuais ou SNPs. Alguns primers foram escolhidos da literatura existente, outros foram desenhados usando o software Primer3 (http://biotools.umassmed.edu/bioapps/primer3_www.cgi).

Mais de um polimorfismo pode ser identificado nas sequiências delimitadas pelos primers 1new e 2 new, 2D6*3_F e 2D6*3_R*, 2D6*10_F e 2D6*10_R, 2D6*41_F e 2D6*41_R (Quadro 1) ${ }^{62}$. 
Quadro 1 - Pares de oligonucleotídeos escolhidos para a amplificação das seqüencias-alvo do gene CYP2D6

\begin{tabular}{|c|c|c|c|c|}
\hline CYP2D6 & & & & \\
\hline Nome & Seqüência (5'-3') & Fragmento & Polimorfismo & Referência \\
\hline 1new & TCCCAGCTGGAATCCGGTGTCG & \multirow{2}{*}{$750 \mathrm{pb}$} & \multirow{2}{*}{$\begin{array}{l}\text { 161G }>\text { C; 1707delT; 1846G }>\text { A; } \\
\text { 1863_1864ins(TTTCGCCCC)2 }\end{array}$} & Hersberger et al., 2000 \\
\hline 2new & GGAGCTCGCCCTGCAGAGACTCCT & & & Hersberger et al., 2000 \\
\hline 2D6*3_F & GCGGAGCGAGAGACCGAGGA & \multirow{2}{*}{$789 \mathrm{pb}$} & \multirow[t]{2}{*}{ 2549delA; 2613_2615delAGA } & Hersberger et al., 2000 \\
\hline $2 \mathrm{D} 6 * 3 \_\mathrm{R} *$ & GTCCCGAGTATGCTCTCGG & & & Renata Canalle \\
\hline 2D6*10_F & GTGCTGAGAGTGTCCTGC & \multirow{2}{*}{$343 \mathrm{pb}$} & \multirow[t]{2}{*}{ 31G>A; 100C>T; 137_138insT } & Naveen et al., 2006 \\
\hline 2D6*10_R & CACCCACCATCCATGTTTGC & & & Naveen et al., 2006 \\
\hline 2D6*41_F & CCGTTCTGTCCCGAGTATGC & \multirow{2}{*}{$340 \mathrm{pb}$} & \multirow[t]{2}{*}{$2850 \mathrm{C}>\mathrm{T} ; 2988 \mathrm{G}>\mathrm{A}$} & Hinrichs et al., 2007 \\
\hline 2D6*41_R & CGGCCCTGACACTCCTTCTT & & & Hinrichs et al., 2007 \\
\hline 2D6*17_F & GATCCTGGCTTGACAAGAGG & \multirow{2}{*}{$280 \mathrm{pb}$} & \multirow[t]{2}{*}{$1023 \mathrm{C}>\mathrm{T}$} & \\
\hline 2D6*17B_R & AGCTCGGACTACGGTCATCA & & & \\
\hline 2D6_2_F & TCTTCTTCACCTCCCTGCTG & \multirow{2}{*}{$250 \mathrm{pb}$} & \multirow[t]{2}{*}{$4180 \mathrm{G}>\mathrm{C}$} & \\
\hline 2D6_2_R & CTGAGGAGGATGATCCCAAC & & & \\
\hline 2D6_2P_F & CCTCCCACAAAAGACAGGAT & \multirow{2}{*}{$292 \mathrm{pb}$} & \multirow[t]{2}{*}{$-1584 \mathrm{C}>\mathrm{G}$} & \\
\hline 2D6_2P_R & CATGTTGGCCAGGCTAGT & & & \\
\hline
\end{tabular}

* Primer gentilmente cedido pela Dra. Renata Canalle

\subsubsection{PCR de Seqüenciamento}

O método desenvolvido por Sanger et al.,1977, envolve a utilização de 2', 3' dideoxinucleotídeos trifosfatos (ddNTP), que não apresentam o grupo 3' hidroxila em suas estruturas $^{65}$. Cada ddNTP é marcado com uma molécula fluorescente diferente. Durante a elongação da fita de DNA, quando um ddNTP é incorporado ele impede a continuidade de extensão da fita. Fragmentos de diferentes tamanhos são gerados dependendo da posição onde um ddNTP foi incorporado. Estes fragmentos são submetidos a eletroforese capilar no seqüenciador ABI3100 (Applied Biosystems, Foster City, CA, USA), que detecta a fluorescência emitida pelos ddNTPs e transforma os resultados da eletroforese em um eletroferograma.

Para a identificação do polimorfismo $-1584 \mathrm{G}>\mathrm{C}$, na região promotora do gene CYP2D6, a PCR foi padronizada segundo as seguintes condições: Buffer $\mathrm{MgCl}_{2}$ free $1 \mathrm{x}$ 
(Invitrogen, CA, USA); 0,125 mM de dNTPs; 2,25 mM de $\mathrm{MgCl}_{2}$ (Invitrogen, CA, USA); 0,2 uM de cada oligonucleotídeo 2D6_2P_F e 2D6_2P_R (Dialab, Belo Horizonte, MG, Brasil); 0,45 M de betaína (Sigma, Saint Louis, Missouri, USA); 0,05 U/ $\mu \mathrm{L}$ de Platinum ${ }^{\circledR}$ Taq DNA Polymerase (Invitrogen, CA, USA); 0,5 ng/ $\mu \mathrm{L}$ de DNA; e agua Milli Q q.s.p. 10,00 $\mu \mathrm{L}$. A termociclagem utilizada foi a seguinte: 3 minutos a $94{ }^{\circ} \mathrm{C}$ seguido de 40 ciclos de 30 segundos a $94{ }^{\circ} \mathrm{C}, 20$ segundos a $60,0{ }^{\circ} \mathrm{C}, 30$ segundos a $72{ }^{\circ} \mathrm{C}$ e, por fim, 5 minutos a $72{ }^{\circ} \mathrm{C}$. O produto amplificado foi aplicado em gel de agarose $1 \%$ corado com brometo de etídio [0,4 $\mu \mathrm{L} / \mathrm{mL}$ ] e visualizado sob luz UV.

Depois de realizada a PCR, seus produtos foram seqüenciados segundo a reação: 1,0 $\mu \mathrm{L}$ de Big Dye Terminator v.3 (Applied Biosystems, Foster City, CA, USA); 2,0 uL de Buffer (200 mM Tris HCI pH 9.0; 5 mM MgCb); 0,32 $\mu \mathrm{M}$ de oligonucleotídeo sense, 0,45 M de betalna; $1,0 \mu \mathrm{L}$ do produto de PCR previamente amplificado e água Milli Q q.s.p. 10,00 $\mu \mathrm{L} \mathrm{A}$ termociclagem utilizada foi a seguinte: 3 minutos a $95{ }^{\circ} \mathrm{C}$ seguido de 37 ciclos de 20 segundos a $95{ }^{\circ} \mathrm{C}, 20$ segundos a $55^{\circ} \mathrm{C}$ e, por fim, 4 minutos a $60{ }^{\circ} \mathrm{C}$.

A reação de seqüenciamento foi então precipitada com Isopropanol 70\% (Merck KGaA, Darmstadt, Germany) e Etanol 75\% (Merck KGaA, Darmstadt, Germany). As amostras são analisadas no aparelho seqüenciador de DNA ABI PRISM ${ }^{\circledR} 3100$ Genetic Analyzer (Applied Biosistems, Foster Cty, CA).

A identidade dos produtos da amplificação foi confirmada utilizando-se a ferramenta BLAST $^{66}$ para busca por seqüências similares em bancos de dados.

Para os demais polimorfismos investigados nos genes CYP2D6, CYP2C19 e CYP2C9, as PCRs foram padronizadas nas mesmas condições: Buffer $\mathrm{MgCl}_{2}$ free 1x (Invitrogen, CA, USA); 0,125 mM de dNTPs; 2,25 mM de cloreto de magnésio (Invitrogen, CA, USA); 0,2 $\mu \mathrm{M}$ de cada oligonucleotídeo sense e antisense (Dialab, Belo Horizonte, MG, Brasil); 5\% de Dimetilsulfóxido -DMSO- (Merck KGaA, Darmstadt, Germany)', 0,05 U/ $\mu \mathrm{L}$ de Platinum ${ }^{\circledR}$ Taq DMA Polymerase (Invitrogen, CA, US/A); 0,5 ng/ $\mu \mathrm{L}$ de DNA; e água Milli Q q.s.p. 10,0 $\mu \mathrm{L}$. A termociclagem utilizada foi a seguinte: 3 minutos a $94{ }^{\circ} \mathrm{C}$ seguido de 40 ciclos de 30 segundos a $94{ }^{\circ} \mathrm{C}, 20$ segundos a $63,0{ }^{\circ} \mathrm{C}, 30$ segundos a $72{ }^{\circ} \mathrm{C}$ e, por fim, 5 minutos a $72{ }^{\circ} \mathrm{C}$. 
Os produtos amplificados foram então verificados em gel de Agarose 1\% corado com brometo de etídio [0,4 $\mu \mathrm{L} / \mathrm{mL}$ ] e visualizado sob luz UV.

A seguir, foram realizadas as reações de sequienciamento também padronizadas nas mesmas condições para todos os polimorfismos: 1,0 $\mu \mathrm{L}$ de Big Dye Terminator v.3 (Applied Biosystems, Foster City, CA, USA); 2,0 $\mu$ L de Save Money Buffer (200 mM Tris HCI pH 9.0; 5 mM MgCI2); 0,32 $\mu \mathrm{M}$ de oligonucleotídeo; 5\% de Dimetilsulfóxido -DMSO- (Merck KGaA, Darmstadt, Germany); 1,0 $\mu \mathrm{L}$ do produto de PCR e água Milli Q q.s.p. 10,0 $\mu$ l. A termociclagem utilizada foi a seguinte: 3 minutos a $95{ }^{\circ} \mathrm{C}$ seguido de 37 ciclos de 20 segundos a $95{ }^{\circ} \mathrm{C}, 20$ segundos a $55^{\circ} \mathrm{C}$ e, por fim, 4 minutos a $60{ }^{\circ} \mathrm{C}$.

As reações de seqüenciamento foram precipitadas conforme descrito anteriormente. Ao termino da precipitação, as amostras foram analisadas no seqüenciador de DNA ABI PRISM $^{\circledR} 3100$ Genetic Analyzer (Applied Biosystems, Foster City, CA).

A identidade dos produtos da amplificação foi também confirmada utilizando-se a ferramenta BLAST ${ }^{66}$.

Os eletroferogramas gerados pelo seqüenciador foram então analisados nos programas Chromas $^{\circledR}$ (2001 Technelysium Pty Ltd) e FinchTV ${ }^{\circledR}$ (2004 - 2006 Geospiza, Inc.).

\subsubsection{Long template PCR para detecção da duplicação do gene CYP2D6 e do alelo CYP2D6*5}

Steen et al, $(1995)^{60}$, foi o primeiro a utilizar a long template PCR com sucesso para a identificação do alelo $C Y P 2 D 6 * 5$. Devido a grande homologia com os pseudogenes $C Y P 2 D 8$ e CYP2D7, torna-se difícil a escolha de oligonucleotídeos para a long template PCR. Baseado nesta informação, este cientista selecionou dois pares de oligonucleotídeos que se anelam a regiões não homologas do DNA. O oligonucleotídeo sense, anela na inserção de 1,6 kb downstream do gene CYP2D7 e o oligonucleotídeo antisense, possui uma sequiência que anela em uma região aproximadamente 3,5 kb downstream do gene CYP2D6 (Figura 9). Com estes oligonucleotídeos foi possível amplificar um produto de PCR de 3,5 kb na presença do alelo deletado de $13 \mathrm{~kb}$. Um produto de $15 \mathrm{~kb}$ indicaria a presença do alelo selvagem, entretanto, 
devido a limitações da reação, a formação deste produto e ignorada. Johansson et al. (1996) descreveu um diferente método de long PCR no qual um fragmento de $6 \mathrm{~kb}$ é gerado na presença do alelo $* 5$. O oligonucleotídeo sense utilizado neste ensaio é específico para o éxon 9 do $C Y P 2 D 7$, enquanto que o antisense esta localizado na mesma região que flanqueia CYP2D6 como o oligonucleotídeo utilizado por Steen et al. (1995) ${ }^{60}$ (Figura 9). O método desenvolvido por Johansson et al. (1996) ${ }^{67}$ não amplifica nenhum fragmento que indica a presença do alelo selvagem. Na reação de multiplex long PCR descrita por Hersberger et al. $2000^{42}$, dois produtos de amplificação são gerados simultaneamente: um indica a deleção do gene CYP2D6 (fragmento de 3,2 kb) e o outro, indica o alelo selvagem (fragmento de 5,1 kb) (Figura 9). Ambos os oligonucleotídeos sense e antisense utilizados para a identificação do alelo *5 estão localizados na mesma região não-homóloga, usada por Steen et al. $1995{ }^{68}$.

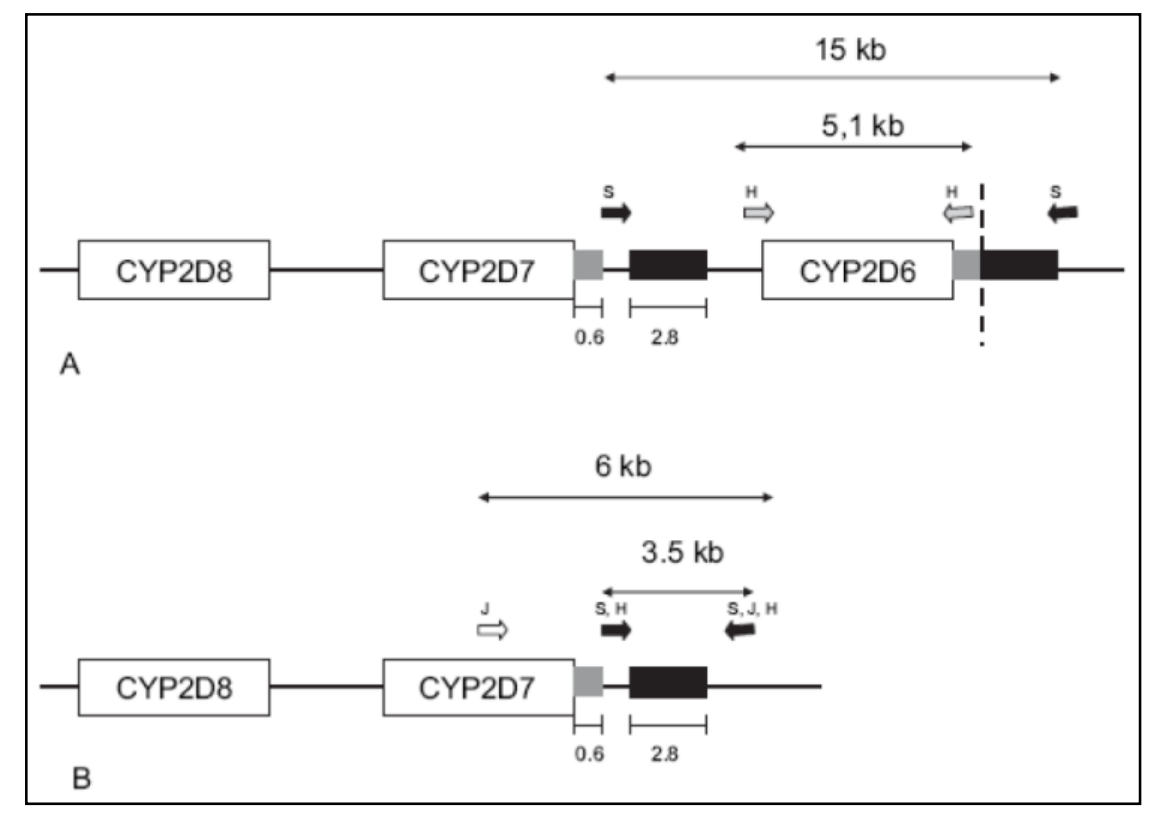

Figura 9. Esquema onde é mostrado o método long $P C R$ para a detecção do alelo $C Y P 2 D 6 * 5$. A linha vertical tracejada mostra o início da deleção. Na figura A representa o tipo selvagem do gene CYP2D6. Na figura B mostra a representação da deleção do gene completo CYP2D6. Fonte: Meijerman, 2007

Para a identificação da duplicação do gene CYP2D6, Johansson et al.,1996 utilizou um par de oligonucleotídeos: o sense que se anela a uma região do éxon 9 e o antisense anela a uma região do íntron 2 do gene CYP2D6 (Figura 10) juntos, estes oligonucleotídeos geram um produto de amplificação de $10 \mathrm{~kb}$ que indica a duplicação do gene ${ }^{67}$. Lundqvist et al., 1999 desenvolveu um método que amplifica um fragmento específico de 3,5 kb que também indica a duplicação do gene. Este fragmento de $3,5 \mathrm{~kb}$ foi obtido por meio da combinação de 
um específico oligonucleotídeo sense para a região que flanqueia o gene CYP2D6 e um oligonucleotídeo antisense para uma região do pseudogene $C Y P 2 D 7^{69}$.

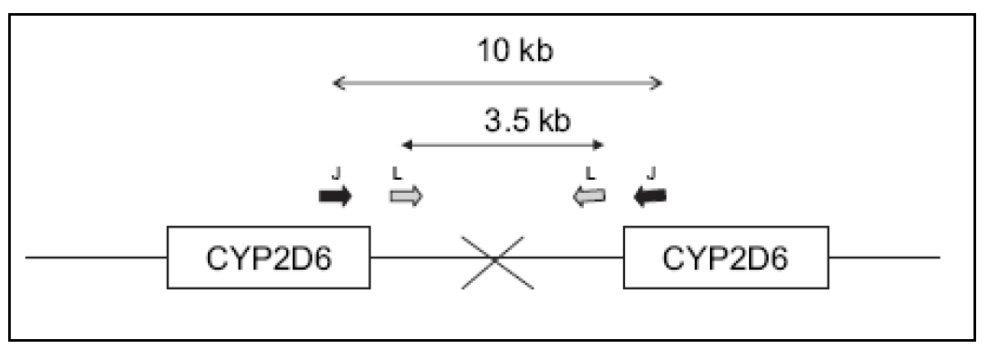

Figura 10. Esquema onde é mostrado o método long $P C R$ para a detecção da duplicação do gene CYP2D6. A s setas indicam os primers usados por Johansson (primer $J$ ) e Lundqvist (primer L).

Fonte: Meijerman, 2007

Lovlie et al. (1996) desenvolveu um método baseado na identificação de uma seqüência homóloga de $3,4 \mathrm{~kb}$ presente na região downstream do gene CYP2D6 e do pseudogene $C Y P 2 D 7^{70}$. Um par de oligonucleotídeos foi utilizado como um controle interno da PCR gerando um fragmento de 5,2 kb da região entre os genes CYP2D7 e CYP2D6. Este mesmo par de oligonucleotídeo amplifica um fragmento de 3,6 kb na presença da duplicação do gene $C Y P 2 D 6^{68}$ (Figura 11).

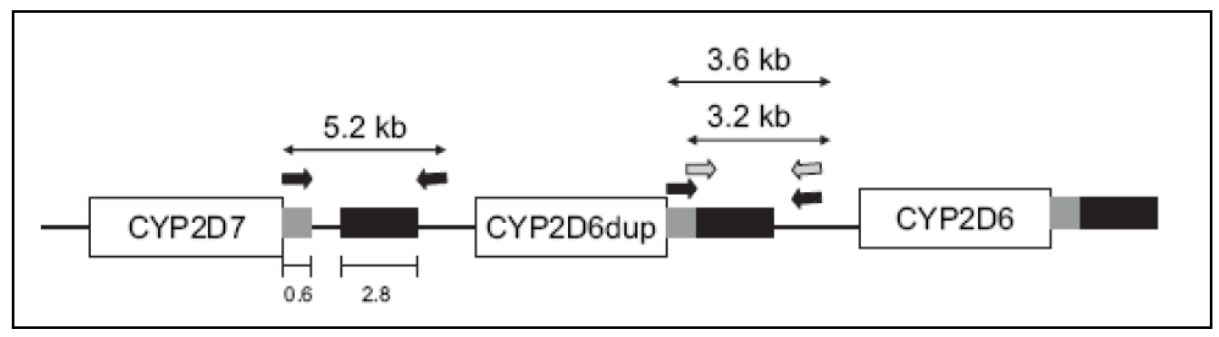

Figura 11. Esquema onde é mostrado o método long $P C R$ para a detecção da duplicação do gene CYP2D6 segundo o método descrito por Lovlie et al., 1996. As regiões de cor cinza e preta são seqüencias praticamente idênticas às seqüencias da região intergênica. As setas pretas indicam a posição dos primers que controlam o controle interno $(5,2 \mathrm{~kb})$. As setas cinzas mostram a posição dos primers que detectam a amplificação $(3,6 \mathrm{~kb})$.

Fonte: Meijerman, 2007.

Em nosso estudo, o primeiro método escolhido para a identificação do alelo CYP2D6*5 e da duplicação do gene CYP2D6 foi a long template PCR. Para esta técnica, oligonucleotídeos foram selecionados a partir de uma revisão da literatura (Quadros 2 e 3). 
Devido ao grande numero de oligonucleotídeos, cada par (sense + antisense) foi designado como um conjunto representado por um número.

Quadro 2 - Primers usados para a detecção do alelo CYP2D6*5. *2D6_del_H2r é um primer modificado do primer DPKlow

\begin{tabular}{|c|c|c|c|c|c|}
\hline & & Primer & Fragn & to $(\mathbf{K b})$ & \\
\hline Conjunto & Nome & Seqüência (5'-3') & Deleção & Wild-Type & Referência \\
\hline & 2D6_del_Sf & ACCGGGCACCTGTACTCCTCA & & & Steen et al., 1995 \\
\hline 1 & 2D6_del_Sr & GCATGAGCTAAGGCACCCAGA & & 1,0 & Steen et al., 1995 \\
\hline 0 & 2D6_del_Jf & GCCACTCTGGTGTCGTCAGCTTT & 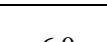 & & Johansson et al., 1996 \\
\hline 2 & 2D6_del_Jr & GGCATGAGCTAAGGCACC & & & Johansson et al., 1996 \\
\hline & 2D6_del_H2r* & GCCGACTGAGCCTGGGAGGTAGGTA & & & Hersberger et al., 2000 \\
\hline$J$ & DPK up & GTTATCCCAGAAGGCTTTGCAGGCTTCA & & $J_{11}$ & Hersberger et al., 2000 \\
\hline & D low & CAGGCATGAGCTAAGGCACCCAGAC & & & Hersberger et al., 2000 \\
\hline & D up & CACACCGGGCACCTGTACTCCTCA & & & Hersberger et al., 2000 \\
\hline
\end{tabular}

Quadro 3 - Primers usados para a detecção de duplicação do gene CYP2D6

\begin{tabular}{|c|c|c|c|c|c|}
\hline & & Primer & \multicolumn{2}{|c|}{ Fragmento $(\mathrm{Kb})$} & \\
\hline Conjunto & Nome & Seqüência (5'-3') & Duplicação & Wild-type & Referência \\
\hline \multirow{2}{*}{4} & 2D6_dup_Jf & GCCACCATGGTGTCTTTGCTTTC & \multirow{2}{*}{10,0} & \multirow{2}{*}{ - } & Johansson et al., 1996 \\
\hline & 2D6_dup_Jr & ACCGGATTCCAGCTGGGAAATG & & & Johansson et al., 1996 \\
\hline \multirow{2}{*}{5} & 2D6_dup_Lf & CCTGGGAAGGCCCCATGGAAG & \multirow{2}{*}{3,5} & \multirow{2}{*}{ - } & Lundqvist et al., 1999 \\
\hline & 2D6_dup_Lr & CAGTTACGGCAGTGGTCAGCT & & & Lundqvist et al., 1999 \\
\hline \multirow{2}{*}{6} & 2D6_dup_CNf & TCCCCCACTGACCCAACTCT & \multirow{2}{*}{3,6} & \multirow{2}{*}{5,2} & Lovlie et al., 1996 \\
\hline & 2D6_dup_CNr & CACGTGCAGGGCACCTAGAT & & & Lovlie et al., 1996 \\
\hline
\end{tabular}

O kit GeneAmp ${ }^{\circledR}$ XL (Applied Biosystems, Foster City, CA, USA) foi utilizado nas reações de identificação da duplicação do gene $C Y P 2 D 6$ e do alelo $C Y P 2 D 6 * 5$. As amostras empregadas nestas reações são amostras apresentando possível deleção e possível duplicação de acordo com a PCR em tempo real que determine o CNV do gene CYP2D6.

Seis long template PCRs foram realizadas, cada qual com um conjunto diferente de oligonucleotídeo. Nas reações dos conjuntos 1, 2 e 3, utilizou-se uma amostra de DNA com uma possível deleção do gene $C Y P 2 D 6$. Nos conjuntos 4, 5 e 6, o DNA empregado foi uma amostra com uma possível duplicação do gene $C Y P 2 D 6$. Para que a reação ocorresse, fez-se necessária preparação dos chamados "lower mix" e do "upper mix". Depois do lower mix ser 
submetido à etapa de hot start o upper mix é adicionado a reação. O lower e o upper mix de cada reação foram compostos de:

- Lower mix: 0,5x de 3.3XL buffer; $2 \mathrm{mM}$ de dNTP Blend; 0,2 uM de cada oligonucleotídeo "F" e "R"; 3,75 mM de $\mathrm{Mg}(\mathrm{OAc})_{2}$ e água DEPC (Invitrogen, CA, USA) q.s.p. $20 \mu \mathrm{L}$

- Upper mix: 0,5x de 3.3XL buffer; $2 \mathrm{U} / \mu \mathrm{L}$ de rTh DNA Polymerase, XL (Applied Biosystems, Foster City, CA, USA); 2,5 ng/ $\mu \mathrm{L}$ de DNA e água DPEC (Invitrogen, CA, USA)q.s.p. $30 \mu \mathrm{L}$.

O termociclador usado foi o Gene Amp® PCR System 9700 (Applied Biosystems). Apos o hot start de $80{ }^{\circ} \mathrm{C}$ por 10 minutos e $4{ }^{\circ} \mathrm{C}$ por 5 minutos, a seguinte termociclagem ocorreu: $94{ }^{\circ} \mathrm{C}$ por 1 minuto seguido de 35 ciclos de $94{ }^{\circ} \mathrm{C}$ por 1 minuto, $68{ }^{\circ} \mathrm{C}$ por 10 minutos e, finalmente, 10 minutos a $72{ }^{\circ} \mathrm{C}$. O produto de PCR foi aplicado em gel de agarose a $0,5 \%$ corado com brometo de etídio $[0,4 \mu \mathrm{L} / \mathrm{mL}]$ e visualizado sob luz UV.

A seguir, um novo teste foi realizado com o conjunto de oligonucleotídeos 3 , com a finalidade de verificar se a multiplex long PCR (que utiliza dois pares de oligonucleotídeos) descrita por Hersberger et al. (2000) funcionaria apropriadamente com o Kit GeneAmp ${ }^{\circledR}$ XL (Applied Biosystems, Foster City, CA, USA). A reação e descrita a seguir:

- Lower mix: 0,5x de 3.3XL buffer; 0,18 mM de dNTP Blend; 0,34 mM dos oligonucleotídeos Dup e Dlow e, 0,68 mM dos oligonucleotídeos 2D6_del_H2R e DPKup; $3,4 \mathrm{mM}$ de $\mathrm{Mg}(\mathrm{OAc})_{2}$, volume final de $22 \mu \mathrm{L}$.

- Upper mix: 0,5x de 3.3XL buffer; $2 \mathrm{U} / \mu \mathrm{L}$ de rTh DNA Polymerase, XL (Applied Biosystems); 5,36 ng/ $\mu \mathrm{L}$ de DNA e água DEPC (Invitrogen, CA, USA) q.s.p. $28 \mu \mathrm{L}$.

Usamos as mesmas amostras de DNA da reação anterior. O termociclador utilizado foi o Gene Amp ${ }^{\circledR}$ PCR System 9700 (Applied Biosystems). Apos o hot start de $80{ }^{\circ} \mathrm{C}$ por 10 minutos e $4{ }^{\circ} \mathrm{C}$ por 5 minutos, a ciclagem foi a seguinte: $94^{\circ} \mathrm{C}$ por 2 minutos seguido de 40 ciclos de $94{ }^{\circ} \mathrm{C}$ por 1 minuto, $60{ }^{\circ} \mathrm{C}$ por 45 segundos e $68{ }^{\circ} \mathrm{C}$ por 5 minutos. $\mathrm{O}$ produto de 
PCR foi aplicado em gel de agarose a 0,8\% corado com brometo de etídio $[0,4 \mu \mathrm{L} / \mathrm{mL}]$ e visualizado sob luz UV.

O termociclador utilizado foi o Gene Amp ${ }^{\circledR}$ PCR System 9700 (Applied Biosystems): A ciclagem foi a seguinte: $94^{\circ} \mathrm{C}$ por 2 minutos seguido de 40 ciclos de $94{ }^{\circ} \mathrm{C}$ por 1 minuto, 60 ${ }^{\circ} \mathrm{C}$ por 45 segundos e $68{ }^{\circ} \mathrm{C}$ por 5 minutos. O produto de PCR foi aplicado em gel de agarose a $0,8 \%$ corado com brometo de etídio $[0,4 \mu \mathrm{L} / \mathrm{mL}]$ e visualizado sob luz $\mathrm{UV}$.

4.6.10 PCR em Tempo Real para a quantificação do número de Cópias do gene CYP2D6

As técnicas de PCR em tempo real para a quantificação de DNA permitiram o desenvolvimento de métodos sensíveis que são capazes de discriminar deleções de genes, duplicações e multiplicações. Com esta técnica, compostos fluorescentes são utilizados para monitorizarão do processo de PCR no momento que a reação ocorre. As curvas de amplificação da PCR mostram a quantidade de fluorescência na fase exponencial da reação que pode ser utilizada para calcular a relativa quantidade do material inicial ${ }^{68}$.

Um dos sistemas mais comumente utilizados são as sondas TaqMan para amplificar seqüências-alvo e simultaneamente gerar um sinal do produto de PCR. Em uma reação com o sistema TaqMan®, três específicos oligonucleotídeos: um sense e outro antisense além de uma sonda TaqMan ${ }^{\circledR}$. A sonda está ligada a um fluoróforo e um quencher. Enquanto a sonda não estiver ligada ao DNA, o sinal da fluorescência é baixo devido a presença do quencher. Quando a sonda está anelada ao DNA, o quencher é liberado do fluoróforo e o sinal fluorescente pode ser medido ${ }^{68}$. Esta técnica precisa de um controle endógeno, que deve ser um gene de cópia única no genoma haplóide, que é usado como normalizador. O gene que foi usado como normalizador foi RNAse P (TaqMan endogenous control kit (Applied Biosystems, Foster City, CA, USA).

Realizou-se a PCR no aparelho 7500 Real-Time PCR System (/applied Biosystems, Foster City, CA, USA) e 7500 System SDS Software (Applied Biosystems, Foster City, CA, USA). As reações foram avaliadas em triplicata. 
As condições de reação foram as seguintes: 1,25x de Tag/Wan ${ }^{\circledR}$ Gene Expression Master Mix (P/N: 4374657; Applied Biosystems, Foster City, CA, USA); $1 \mu \mathrm{M}$ de cada oligonucleotídeo sense e antisense; 0,367 [ $\mu \mathrm{M}$ de TaqMan ${ }^{\circledR}$ probe $[11,76(\mu \mathrm{M}] ; 1,25 \mathrm{ng} / \mu \mathrm{L}$ de DNA; 0,08 M de betaína (Sigma, Saint Louis, Missouri, USA) e água DEPC (Invitrogen, CA, USA) q.s.p. $15 \mu \mathrm{L}$ A reação do controle endogeno RNase P foi a seguinte: 1,25x de TaqMan ${ }^{\circledR}$ Gene Expression Master Mix (P/N: 4374657; Applied Biosystems, Foster City, CA, USA); $1 \mathrm{x}$ de RANase P; $1,25 \mathrm{ng} / \mu \mathrm{L}$ de DNA e água DEPC (Invitrogen, CA, USA). A termociclagem usada é descrita a seguir: 2 minutos a $50{ }^{\circ} \mathrm{C}, 10$ minutos a $95^{\circ} \mathrm{C}$ seguido de 40 ciclos de 15 segundos a $96^{\circ} \mathrm{C}$ e 1 minuto a $60^{\circ} \mathrm{C}$.

O objetivo da PCR em tempo real foi separar as amostras em diferentes grupos, de acordo com o número de cópias do gene CYP2D6 que elas possuem. Estes grupos são: presença de um alelo ou deleção de ambos, presença dos dois alelos (genótipo "normal") e a presença de três ou mais alelos (duplicação, amplificação ou multiplicação). A separação das amostras nestes três grupos foi possível após a elaboração de um modelo de regressão logística multinomial.

4.6.11 Determinação dos fenótipos preditos pelo método de seqüenciamento

Na classificação dos fenótipos preditos para CYP2D6 a presença de um alelo funcional $(C Y P 2 D 6 * 1$ ou $C Y P 2 D 6 * 2)$ determinou o fenótipo $\mathrm{EM}^{71,72}$. Homozigotos para dois alelos funcionais ou heterozigotos para um alelo funcional duplicado $\left(C Y P 2 D 6^{*} 1 \times \mathrm{N}\right.$ ou $C Y P 2 D 6 * 2 \times \mathrm{xN})$ e um alelo não-funcional $(C Y P 2 D 6 * 3, * 4, * 5, * 6, * 15, * 40)$ também foram classificados como $\mathrm{EMs}^{73}$. Dois alelos de atividade intermediaria (CYP2D6*9, *10,*17,*41) combinados ou, a combinação de um alelo de atividade intermediaria com uma variante não funcional foi classificado como IM. Indivíduos UMs foram definidos como portadores de uma duplicação ou multiplicação de um alelo ativo em conjunto com um alelo funcional (Sistonem et al., 2007). Os PMs foram definidos como homozigotos para alelos não funcionais $C Y P 2 D 6 * 3, * 4, * 5, * 6, * 15, * 40^{71,72}$ (Quadro 4). 
Quadro 4 - O fenótipo predito é o resultado da combinação dos genótipos dos alelos.

\begin{tabular}{|c|c|}
\hline Fenótipo Predito & Genótipo de Alelos \\
\hline EM & EM + EM; EM + PM; EM + IM; EM X N + PM \\
\hline IM & IM + IM; IM + PM \\
\hline UM & EM x N \\
\hline PM & PM + PM \\
\hline
\end{tabular}




\subsection{Voluntários}

Dos 78 voluntários que participaram do estudo, 3 abandonaram o estudo por razões não relacionadas a complicações técnicas.

\subsection{Fenotipagem}

Para os experimentos de fenotipagem, inicialmente foi adicionado PI (DM-3 ou DX4), de concentração conhecida, às amostras de urina permitindo monitorar perdas durante o processo. A seguir, foi realizada uma extração líquido / líquido. Para isso, adicionou-se o tampão bicarbonato para a manutenção do $\mathrm{pH}$, possibilitando que o analito e o PI permanecessem na forma não-ionizada e pudessem ser facilmente extraídos através da mistura de solvente orgânico (solução éter etílico / diclorometano) usada. A fase orgânica, na qual o analito e PI encontravam-se, foi transferida para um novo tubo e levada para dessecação através de fluxo de nitrogênio a $40^{\circ} \mathrm{C}$, concentrando o analito e o PI e possibilitando a evaporação dos solventes orgânicos que poderiam danificar a coluna cromatográfica. Então, o precipitado foi reconstituído numa solução semelhante à fase móvel do HPLC e injetado para análise quantitativa através de cromatografia líquida de alta eficiência acoplada à espectrometria de massa.

O método foi testado e validado para uma linearidade de 5 a $1000 \mathrm{ng} / \mathrm{mL}$ para DM e DX, a fim de se confirmar a precisão e a precisão do método em análise.

As curvas de calibração testadas para a validação do método usaram as seguintes calibrações: 5, 10, 20, 50, 100, 200, 500 e 1000 ng / mL para DM e DX. O LOQ foi de 5 ng / mL para DM e DX, consideradas suficientes para a caracterização do perfil farmacocinético de cada voluntário.

As variabilidades inter-ensaio e intra-ensaio foram asseguradas por meio das concentrações de amostragem de QCs, as quais foram validadas pelo método nas seguintes concentrações: $15 \mathrm{ng} / \mathrm{mL}$ para QCA, $150 \mathrm{ng} / \mathrm{mL}$ para QCB e $750 \mathrm{ng} / \mathrm{mL}$ para QCC, tanto para a droga mãe DM quanto para o seu metabólito DX. 
Nesses ensaios de fenotipagem, os tempos de retenção dos analitos e dos PIs foram: 1,5 s para DX e DX-D4 e 1,8 s para DM e DM-3. Nenhuma interferência significativa foi observada nos tempos de retenção do fármaco DM, de seu metabólito DX e dos PIs (DM-3 e DX-4). O tempo de corrida cromatográfica foi de $5 \mathrm{~min}$.

Para a definição dos íons a serem monitorados, do analito e dos PIs, fez-se o espectro total das moléculas de DM, DM-3, DX e DX-4 protonadas. Através da análise de espectro total, os íons mais abundantes foram selecionados e fragmentados. Simultaneamente, todos os parâmetros do equipamento foram escolhidos e ajustados. Dessa forma, os íons com maior e melhor definições para as finalidades analíticas foram: 272,2 > 147,3 para DM; 275,3 > 150,2 para DM-3; 258,0 > 157,1 para DX; e 262,0 > 157,2 para DX-D4.

A análise fenotípica foi realizada nas amostras de urina de cada um dos voluntários, usando-se os Índices Metabólicos (MR) de biotransformação DM/DX ${ }^{55}$ (ANEXO B).

Dos 75 voluntários participantes desse estudo de fenotipagem pelo método de análise com o Sistema HPL / LC-MS-MS, 11 voluntários (3, 18, 24, 26, 28, 44, 47, 53, 63, 69 e 75) foram classificados como Metabolizadores Lentos $(\mathrm{PM}=14.7 \%)$ com Índice Metabólico menores ou iguais a 0,3. Os intervalos dos valores do índice metabólico foram entre 0,3919 e 59,5361 .

Dos 75 voluntários, 64 foram considerados Metabolizadores Normais (EM = 85,3\%). Os intervalos dos valores do índice metabólico foram entre 0,01633 e 0,2751.

Por problemas na quantificação da droga mãe DM nas amostras de urina coletadas não foi possível realizar a classificação dos voluntários 8, 11, 21, 23, 67, 70 e 73 .

\subsection{Genotipagem}

\subsubsection{Método Tetra-Primer e Long PCR}

As reações de PCR que usaram esta metodologia foram bem sucedidas, tanto para o alelo CYP2D6*3 e *4. Foram feitas em triplicatas para poder observar a reprodutibilidade do 
método. Em todas as reações sempre se obtiveram os mesmos produtos de amplificação. Foram feitos mudanças nos tempos de termociclagem e temperatura de anelamento, mesmo assim não obtivemos nenhum produto de amplificação.

As reações para o alelo *6 foram feitos em triplicata e não mostraram nenhum produto de amplificação, e por este motivo, pensamos que abandonar esta metodologia com a esperança de obter, por médio de uma colaboração, alguma amostra de DNA positivo para este alelo e assim poder avaliar se a metodologia estava correta. Também foram feitos alterações nos tempos e temperatura de anelamento e tampouco obtivemos amplificações.

As reações para o estudo do alelo *5 mostraram inespecificidade, aparecendo bandas muitas bandas com diferente peso molecular. No entanto, foram feitas alterações na temperatura de anelamento da reação e os problemas continuaram.

\subsubsection{Análise do Alelo CYP2D6*3}

A análise deste alelo a través das reações de PCR Tetra Primer detectou dois polimorfismos em dois voluntários diferentes. O voluntário 32 mostrou ser um heterozigoto *1 / *3 e sua freqüência alélica é de $1.33 \%$ e apresenta um valor de índice metabólico de 0.269. Já o voluntário 47 mostrou ser, surpreendentemente, um homozigoto para este alelo (*3/*3) e sua frequiência alélica é de $1.33 \%$ e apresenta um valor de índice metabólico de 24.821. A Figura 11 mostra as fotografias das corridas eletroforéticas de todos os voluntários. O Quadro 5 mostra as freqüências deste alelo.

\subsubsection{Análise do Alelo CYP2D6*4}

Um total de 17 voluntários mostrou o polimorfismo do alelo CYP2D6*4. Três deles foram homozigotos $(* 4 / * 4)$ e sua freqüência alélica é de $4 \%$. Quatorze foram heterozigotos $(* 1 / * 4)$ e sua frequiência alélica é de 19\% (Tabela 2). 58 voluntários mostraram ser homozigotos selvagens $(* 1 / * 1)$ e sua freqüência alélica é de $77 \%$ (Quadro 5). 
Quadro 5 - Freqüências genotípicas dos alelos CYP2D6*3 $e * 4$

\begin{tabular}{|c|c|}
\hline Genótipo & Freqüiências, $\%$ \\
\hline$* \mathbf{1} / * \mathbf{3}$ & 1,33 \\
\hline$* \mathbf{3} / * \mathbf{3}$ & 1,33 \\
\hline$* \mathbf{1} / * \mathbf{4}$ & 19 \\
\hline$* \mathbf{4} / * \mathbf{4}$ & 4 \\
\hline
\end{tabular}

Onze dos quatorze (78.57\%) tiveram uma média de razão de 0.165 com desvio padrão de 0.080 e foram considerados EM; três dos quatorze (21.43\%) foram heterozigotos e tiveram uma média de razão de 5.405 com desvio padrão de 7.471 e foram considerados como PM.

Os voluntários que se mostraram ser heterozigotos foram os 4, 5, 18, 25, 33, 35, 38, $39,50,53,65,66,71,74$. Os voluntários homozigotos foram 29, 56, 78. A Figura 12 mostra as fotografias das corridas eletroforéticas de todos os voluntários.

\subsubsection{Análise dos Alelos CYP2D6*3 e*4 em conjunto}

Nenhum voluntário apresentou polimorfismo para os alelos CYP2D6*3 e CYP2D6*4 de forma simultânea. Sendo assim, a freqüência alélica foi de 1,3\% para os alelos CYP2D6*3 e 14\% para o alelo CYP2D6*4. O método de genotipagem por Tetra-Primer nos permitiu extrair freqüências alélicas do alelo CYP2D6*3 e *4. O Quadro 6 mostra o valor das freqüências destes dois alelos.

Quadro 6 - Freqüências alélicas dos alelos CYP2D6*3e*4.

\begin{tabular}{|c|c|c|}
\hline Alelo & Número de alelos $(\mathbf{n}=\mathbf{1 5 0}) *$ & Frequiência alélica, \% \\
\hline$* 3$ & $2 / 150$ & 1,3 \\
\hline$* 4$ & $21 / 150$ & 14 \\
\hline
\end{tabular}

*75 amostras multiplicadas pelos 2 alelos de cada (materno e paterno) $=150$ 


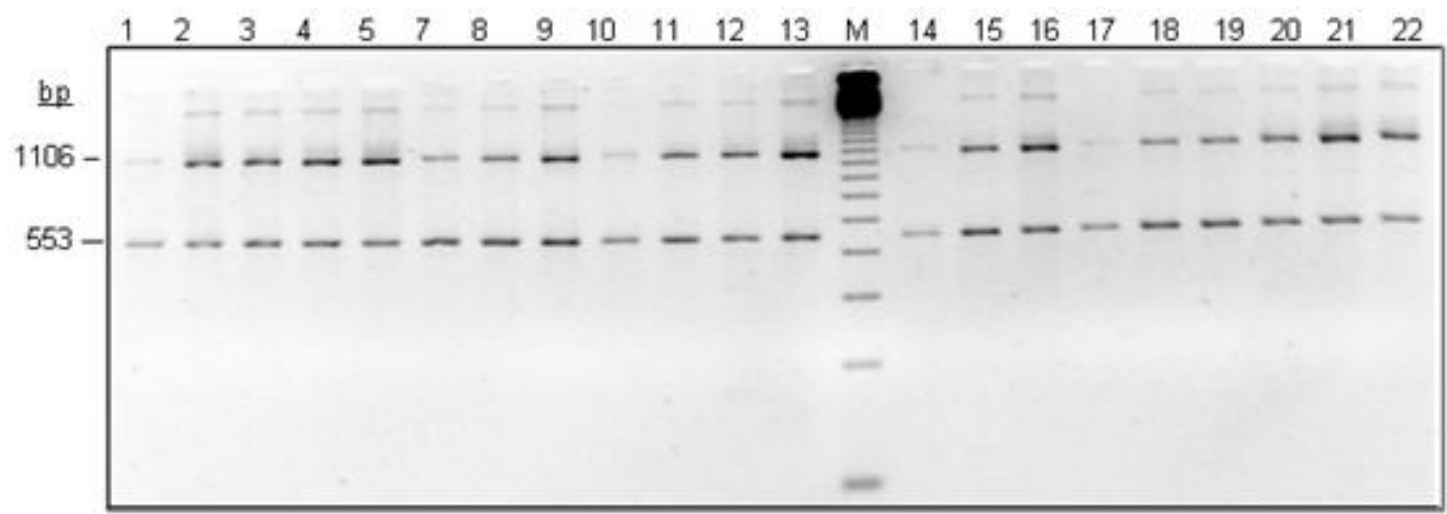

$\begin{array}{lllllllllllllllllllllll}\text { bp } & 23 & 24 & 25 & 26 & 27 & 28 & 29 & 30 & 31 & 32 & 33 & \text { M } & 35 & 36 & 38 & 39 & 40 & 41 & 42 & 43 & 44 & 45\end{array}$
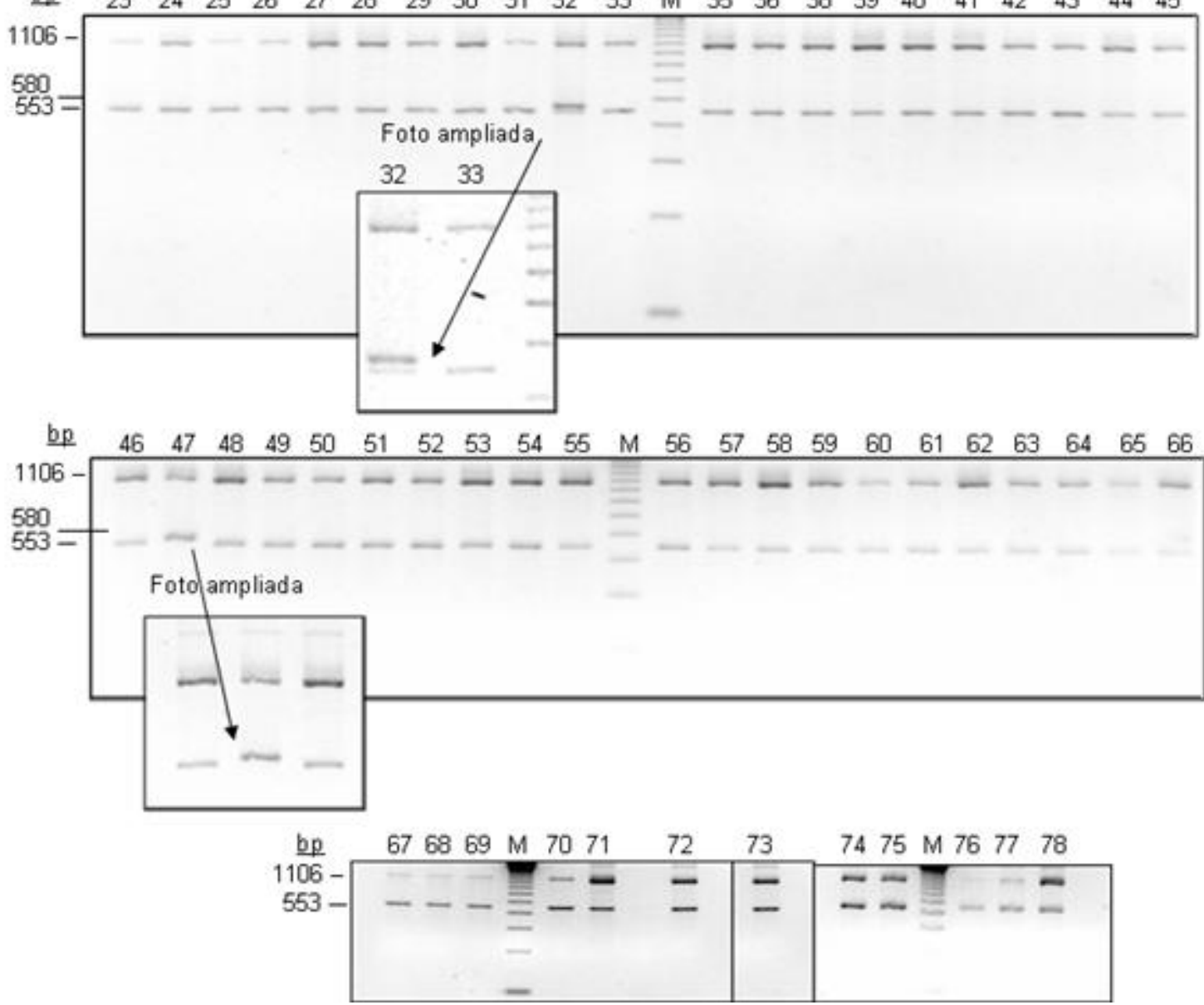

Figura 11. Fotografia das corridas eletroforéticas das PCR do método Tetra Primer para o gene CYP2D6*3. Maracador de $123 \mathrm{pb}$. 

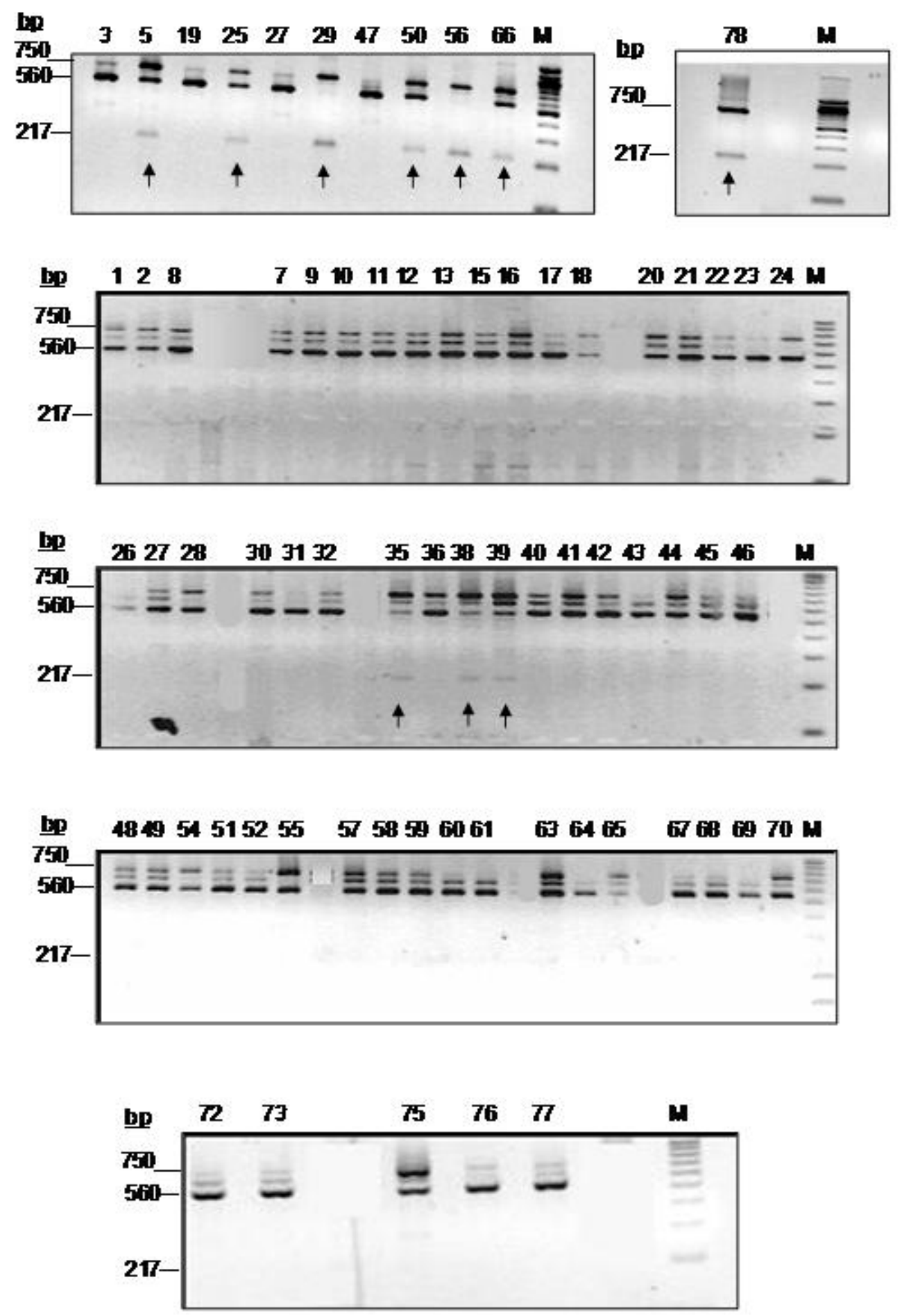

Figura 12. Fotografia das corridas eletroforéticas das PCRs do método Tetra Primer. Marcador de $100 \mathrm{pb}$. 

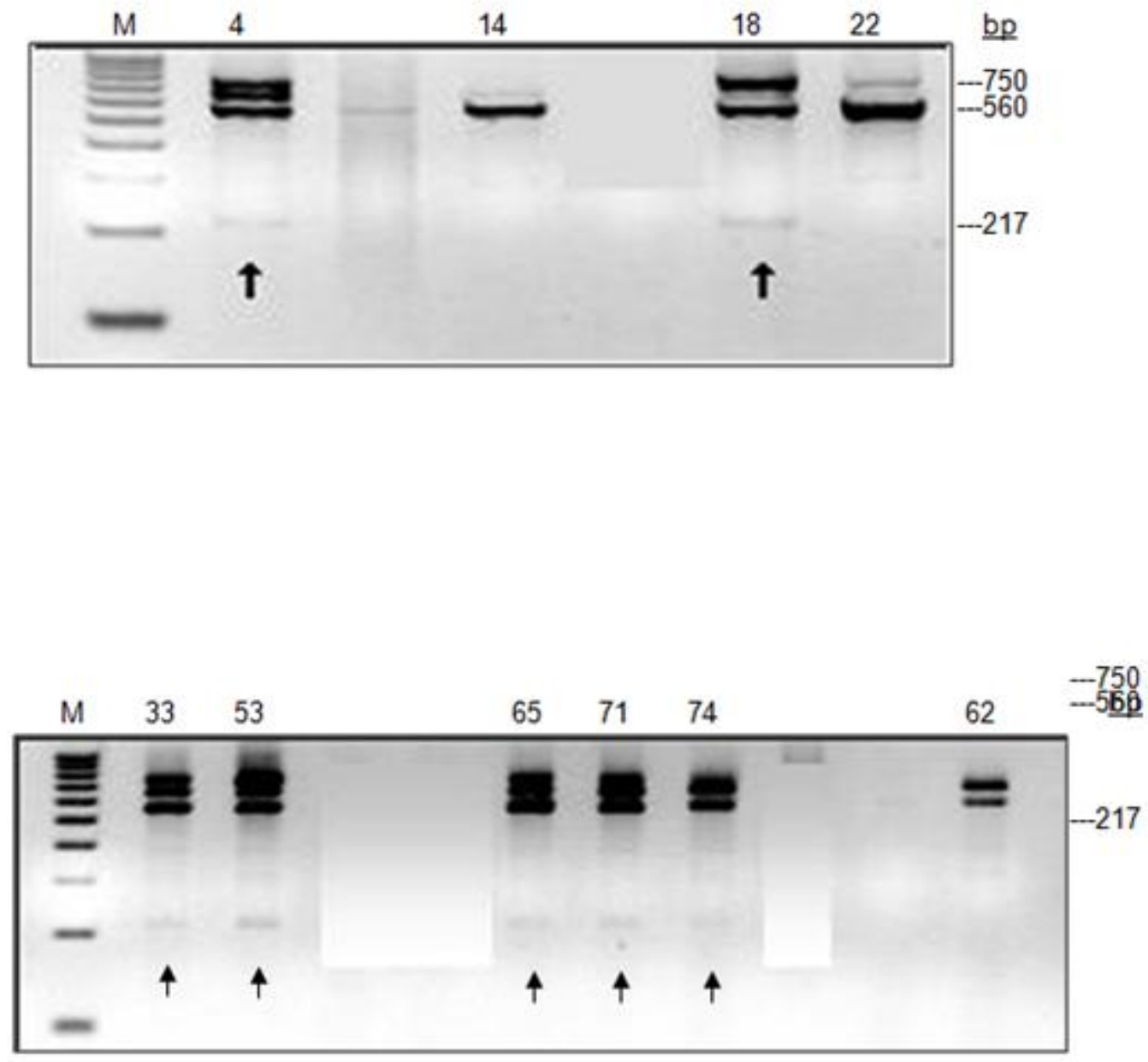

Figura 12. Fotografia das corridas eletroforéticas do CYP2D6*4 (continuação)

\subsubsection{Método de Seqüenciamento}

5.3.2.1 Análise dos Alelos CYP2D6*1, *2, 3,*4, *5,*10, *17, e*41 e seu número de cópias

Este método nos permitiu analisar os alelos CYP2D6*1, *2, 3,*4, *5, *10,*17, e *41. Entretanto, das 75 amostras de DNA que participaram do estudo, somente 19 amostras tiveram algum tipo de condição de serem avaliadas por este método (ANEXO C). As amostras restantes foram degradadas por razões naturais. 
Infelizmente, a quantidade de amostras genotipadas não permitiu gerar uma tabela completa com os resultados de todos os voluntários. Contudo, os resultados obtidos dão conta de uma grande variedade de variantes alélicas que podem explicar os resultados obtidos pela fenotipagem (ANEXO D).

Obtivemos os seguintes resultados com as combinações seguintes:

- 2 voluntários homozigotos selvagens $* 1 / * 1$

- 3 voluntários heterozigotos $* 1 / * 2$

- 1 voluntário heterozigoto $* 1 / * 4$

- 1 voluntário heterozigoto $* 1 / * 41$

- 2 voluntários heterozigotos $* 2 / * 4$

- 3 voluntários heterozigotos $* 2 / * 10$

- 1 voluntário heterozigoto $* 3 / * 5$

- 1 alelos heterozigotos $* 4 / * 5$

Três amostras não tiveram boa qualidade de seqüenciamento e, portanto, não houve um resultado que indique com certeza o perfil fenotípico.

Mediante a análise do número de cópias encontramos um voluntário que apresentou 3 cópias do gene CYP2D6 (alelo *1 / *2). 16 amostras só mostraram duas cópias do gene CYP2D6. Igualmente, por falta de uma boa qualidade de DNA, três foram indeterminadas (Quadro 7). 
Quadro 7 - Resultados das fenotipagens, assim como a análise do número de cópias do gene CYP2D6.

\begin{tabular}{|c|c|c|c|}
\hline Voluntário & Alelo CYP2D6 & CNV & Atividade Enzimática predita \\
\hline 2 & $* 2 * 10$ & 2 & Normal \\
\hline 7 & $* 1 * 2$ & 2 & Normal \\
\hline 9 & $* 1 * 2$ & 3 & Aumentada \\
\hline 18 & $* 2 * 10$ & 2 & Normal \\
\hline 19 & $* 1 * 1$ & 2 & Normal \\
\hline 21 & $* 1 * 41$ & 2 & Normal \\
\hline 27 & $* 2 * 10$ & 2 & Normal \\
\hline 28 & Indeterminado & 2 & \\
\hline 35 & $* 2 * 4$ & 2 & Normal \\
\hline 36 & $* 1 * 1$ & 2 & Normal \\
\hline 38 & $* 1 * 4$ & 2 & Normal \\
\hline 39 & $* 2 * 4$ & 2 & Normal \\
\hline 44 & Indeterminado & indeterminado & \\
\hline 46 & $* 1 * 2$ & indeterminado & \\
\hline 47 & $* 3 * 5$ & 1 & Nula \\
\hline 55 & $* 2$ & 2 & \\
\hline 56 & $* 4 * 5$ & 1 & Nula \\
\hline 70 & $* 1$ & indeterminado & \\
\hline 74 & Indeterminado & 2 & \\
\hline
\end{tabular}

\subsubsection{Comparação dos resultados pelos métodos de Seqüenciamento}

A pouca quantidade de amostras seqüenciadas não permite fazer uma comparação mais completa de todos voluntários. No entanto, ainda é possível fazer uma comparação das 
duas metodologias ao analisar os resultados completos em algumas amostras. O Quadro 8 compara a fenotipagem pelo Índice Metabólico (DM / DX), genotipagem dos alelos *3 e *4 pelo método Tetra-Primer e pelo método de seqüenciamento e análise de número de cópias.

Quadro 8 - Comparação dos resultados por fenotipagem e genotipagem

\begin{tabular}{|c|c|c|c|c|c|c|}
\hline Voluntário & DM / DX & CYP2D6*3 & CYP2D6*4 & Sequenciam. & CNV & Atividade E \\
\hline 2 & 0.0829 & $* 1 / * 1$ & $* 1 / * 1$ & $* 2 * 10$ & 2 & Normal \\
\hline 7 & 0.0438 & $* 1 / * 1$ & $* 1 / * 1$ & $* 1 * 2$ & 2 & Normal \\
\hline 9 & --- & $* 1 / * 1$ & $* 1 / * 1$ & $* 1 * 2$ & 3 & Aumentada \\
\hline 18 & 0.1218 & $* 1 / * 1$ & $* 1 / * 4$ & $* 2 * 10$ & 2 & Normal \\
\hline 19 & 3.7726 & $* 1 / * 1$ & $* 1 / * 1$ & $* 1 * 1$ & 2 & Normal \\
\hline 21 & 0.1428 & $* 1 / * 1$ & $* 1 / * 1$ & $* 1 * 41$ & 2 & Normal \\
\hline 27 & 1.3421 & $* 1 / * 1$ & $* 1 / * 1$ & $* 2 * 10$ & 2 & Normal \\
\hline 28 & 0.0329 & $* 1 / * 1$ & $* 1 / * 1$ & Indeterm. & 2 & --- \\
\hline 35 & 0.2321 & $* 1 / * 1$ & $* 1 / * 4$ & $* 2 * 4$ & 2 & Normal \\
\hline 36 & 0.0316 & $* 1 / * 1$ & $* 1 / * 1$ & $* 1 * 1$ & 2 & Normal \\
\hline 38 & 0.1865 & $* 1 / * 1$ & $* 1 / * 4$ & $* 1 * 4$ & 2 & Normal \\
\hline 39 & 0.2093 & $* 1 / * 1$ & $* 1 / * 4$ & $* 2 * 4$ & 2 & Normal \\
\hline 44 & 0.0246 & $* 1 / * 1$ & $* 1 / * 1$ & Indeterm. & Ind. & --- \\
\hline 46 & 0.0561 & $* 1 / * 1$ & $* 1 / * 1$ & $* 1 * 2$ & Ind. & --- \\
\hline 47 & 24.8214 & $* 3 / * 3$ & $* 1 / * 1$ & $* 3 * 5$ & 1 & Nula \\
\hline 55 & 0.0908 & $* 1 / * 1$ & $* 1 / * 1$ & $* 2$ & 2 & \\
\hline 56 & 59.5361 & $* 1 / * 1$ & $* 4 / * 4$ & $* 4 * 5$ & 1 & Nula \\
\hline 70 & --- & $* 1 / * 1$ & $* 1 / * 1$ & $* 1$ & Ind. & $* 1 / * 1$ \\
\hline 74 & 0.1029 & $* 1 / * 1$ & $* 1 / * 4$ & Indeterm. & 2 & $* 1 / * 1$ \\
\hline
\end{tabular}




\subsubsection{Análise comparativa dos voluntários.}

\section{- Voluntário 9}

Podemos observar que este voluntário apresenta pelo método Tetra Primer um genótipo de normal $(* 1 / * 1)$, pelo método de Seqüenciamento se observa que apresenta um genótipo $(* 1 / * 2)$ e pela análise de CNV apresenta 3 cópias do gene CYP2D6 que caracteriza um fenótipo UM, com atividade enzimática aumentada. Infelizmente o valor do DM/DX não pode ser analisado.

\section{- Voluntário 19}

Os resultados para este voluntário não correspondem entre a fenotipagem (DM/DX) e os dois métodos de genotipagem. Pelos valores da fenotipagem temos o caso de um PM e por ambos os métodos seria o caso de um EM $(* 1 / * 1)$.

\section{- Voluntário 27}

Pelo resultado da fenotipagem o voluntário deve ser caracterizado como um metabolizador lento, mas os resultados das genotipagens o caracterizam como um metabolizador normal; segundo o método Tetra Primer $(* 1 / * 1)$ e pelo método de seqüenciamento $(* 2 / * 10)$.

\section{- Voluntário 47}

Os resultados para este voluntário caracterizam, tanto por fenotipagem quanto por genotipagem, a um metabolizador lento (PM), sendo que pelo método Tetra Primer foi caracterizado como um homozigoto do alelo CYP2D6*3 e pelo método de Seqüenciamento um heterozigoto $* 3 / * 5$, sendo que carregaria um alelo $* 3$ e o segundo alelo teria o gene CYP2D6 deletado. O valor do índice metabólico DM/DX foi 24.8214 . 


\section{- Voluntário 56}

Os resultados para este voluntário mostram um valor alto para a fenotipagem (59.5361). Os resultados das genotipagens mostram que pelo método Tetra Primer foi caracterizado um genótipo homozigoto para o alelo CYP2D6*4 $(* 4 / * 4)$. No caso do método por sequienciamento caracterizou um genótipo $* 4$ / *5, com o alelo *3 e o segundo alelo teria o gene CYP2D6 deletado.

Os outros voluntários apresentaram fenótipos de metabolizadores normais para o método de fenotipagem. Os métodos de genotipagem mostraram, em alguns casos, algum tipo de diferença, apresentando alelos selvagens $(* 1 / * 1)$ ou $(* 1 / * 2)$, que de qualquer maneira correspondem ao fenótipo de metabolizador normal.

Alguns voluntários não tiveram os resultados de fenotipagem e/ou genotipagem determinados, como foi mencionado, devido a problemas técnicos ou por falta de uma boa qualidade de DNA. 
A Farmacogenética é a ciência que estuda a existência de variações nas sequiências de DNA que possam alterar a maneira como o nosso organismo responde ao tratamento com fármacos. Estas mutações ou polimorfismos geralmente estão presentes em diferentes genes que codificam para uma ampla variedade de enzimas, como enzimas envolvidas na absorção de fármacos (relacionados à glicoproteína $\mathrm{P}$, proteína que pode evitar a passagem do fármaco dentro da célula e assim aumentando as concentrações plasmáticas, que dependendo do fármaco pode atingir concentrações tóxicas), metabolizadores de fármacos e em receptores de fármacos. Estes polimorfismos geram fenótipos bem caracterizados, tais como níveis alterados de expressão e / ou a atividade das proteínas que elas codificam, contribuindo na resposta a uma droga ${ }^{74}$. Portanto, a correlação entre polimorfismos de genes relacionados ao transporte de fármacos, como os polimorfismos do gene $M D R 1$, enzimas metabolizadoras de fármacos, como os polimorfismos da superfamília CYP450, refletem na farmacocinética e farmacodinâmica. Caracterizar estes fenótipos e genótipos traz benefícios para o sistema de saúde, pois diminui substancialmente na quantidade de internações ocasionado pela diminuição dos efeitos adversos, fazendo que não sejam usados recursos com tratamentos inadequados com pouca esperança de sucesso. Mas não é o que acontece de maneira rotineira no país, estamos longe dessa realidade.

O estudo destas variações fenotípicas geralmente se realiza usando uma substância teste em indivíduos voluntários sadios, que logo após sua caracterização geram perfis fenotípicos que podem auxiliar no tratamento (escolha do medicamento e de sua posologia). Os perfis fenotípicos geralmente vão mostrar dois grupos de metabolizadores, os metabolizadores normais e lentos, devido à utilização dos índices metabólicos de urina que são diferentes para cada composto. Mas esta metodologia está sendo contestada. Borges et al. 2005, levantou a questão sobre o uso de índices metabólicos de urina não serem um bom índice para identificar estes fenótipos nas populações. A autora mostrou que na literatura não está bem caracterizado o uso de este índice, relatando casos contraditórios em vários estudos. Ela mostrou que o clearance oral é um índice mais robusto que o índice metabólico de urina $^{54}$. Por tal motivo, é importante realizar, além de estudos fenotípicos, estudos genotípicos que forneçam um perfil mais adequado e mais preciso.

Os genes que codificam para as enzimas da superfamília CYP450 são muito polimórficos, codificando para enzimas com fenótipos diversos que podem ter diferentes 
afinidades para diferentes substratos. Este fato é importante, pois os organismos vivos estão sempre rodeados de compostos químicos que, se conseguissem passar ao interior da célula poderia ser nocivo para seu equilíbrio homeostático. Se o sistema enzimático das P450 compreendesse enzimas com substrato definido ou com afinidade muito alta para poucos substratos, não haveria possibilidades de metabolizar um grande número de compostos químicos, sejam naturais ou sintéticos. Os polimorfismos dos genes CYP450 são diversos e com frequiências variáveis, geralmente associados a grupos étnicos. Assim, na atualidade se conhecem os polimorfismos mais importantes associados a um determinado grupo étnico. No Brasil, ao longo de sua história, aconteceram ondas migratórias de muitas culturas e etnias que se estabeleceram no país. Eles trouxeram suas próprias características genotípicas, em especial das CYPP450. Após todos esses eventos, a miscigenação aconteceu e, portanto, os genes polimórficos podem ter sofrido variações que não necessariamente se relacionam com seus ancestrais. Por tal motivo, caracterizar e identificar os polimorfismos e criar um perfil em larga escala é importante. Contudo, o relato de estudos de identificação destes polimorfismos é muito escasso no país. Urge a necessidade de identificar esses polimorfismos a grande escala e criar uma base de dados que possa ajudar a tomar medidas preventivas de saúde pública.

Alguns estudos estão começando a mostrar que além da caracterização e identificação dos polimorfismos na população existem eventos moleculares que também influenciam a expressão das enzimas da CYP450, como por exemplo, o controle mediante microRNAs. Outro tipo de eventos, chamados epigenéticos, como a metilação gênica, tem demonstrado que podem alterar a expressão de algumas enzimas da CYP450 ${ }^{24}$. Falta muito, ainda, para ter uma idéia mais completa dos eventos moleculares intrínsecos da regulação de expressão gênica das CYP450.

Em nosso estudo, caracterizamos os polimorfismos e seus fenótipos por métodos fenotípicos e genotípicos de uma pequena população $(n=75)$ da região de Campinas. As variantes alélicas estudadas pelo método de Tetra Primer foram: CYP2D6*3, *4, *5 e *6. Os estudos dos alelos $* 3$ e $* 4$ foram sucedidos com esta metodologia. Já o estudo das variantes alélicas *5 e *6 não foi bem sucedido, por não contarmos com amostras controles. 
Em nosso estudo, pelo método Tetra Primer, a frequiência alélica para o alelo CYP2D6*3 foi $1,3 \%$ e para o gene $C Y P 2 D 6 * 4$ foi $14 \%$. Esses valores foram muito próximos aos relatados por de Leon et al. 2009 nos Estados Unidos, com uma freqüência de 19,3\% para o alelo $* 4^{75}$. Sistonen et al., 2009 mostrou que as populações da região de América do Sul apresentam freqüências alélicas menores de $1 \%$ para o alelo $* 3^{76}$, valor próximo ao obtido em nosso estudo. Prado et al. 2009, mostrou uma freqüência de $14.5 \%$ para o alelo $* 4^{62}$. Em outro estudo realizado no Rio Grande do Sul por Kohlausch em 2008, mostrou que a freqüência alélica foi $13.2 \%$ para o alelo $* 4^{77}$.

Em nosso estudo, pelo método Tetra Primer, a freqüência alélica para o gene selvagem CYP2D6 foi de $30,66 \%$. Valor próximo ao publicado por Kohlausch $(38,4 \%)$.

Infelizmente não podemos mencionar dados de frequiências alélicas com o método de seqüenciamento, pois a quantidade de amostras de DNA que teve boa qualidade foi de 19 de um total de 75 . Valor insuficiente para poder deduzir freqüências alélicas.

Quando analisamos cuidadosamente o quadro 8, observamos que o voluntário 47 foi caracterizado pelo método Tetra Primer como sendo homozigoto para o alelo *3. Pelo método de seqüienciamento ele foi caracterizado como heterozigoto $* 3 / * 5$. Este resultado pode ser explicado pelo fato de ambas metodologias de genotipagem terem uma abordagem diferente. O método Tetra Primer amplifica na presença de um alelo a banda correspondente a este alelo *3, sem discriminar a presença de outros polimorfismos na amostra de DNA. Como nós não tivemos sucesso com este método na avaliação do alelo *5, então não podemos ter a confirmação desse dado pelo método Tetra Primer. Devemos salientar que o alelo *5 tem uma característica de deleção para o gene CYP2D6, o que significa que usando os primers específicos para o alelo *3 não pode ser detectado pelo método Tetra Primer. Por tal motivo, se a presença for só de um alelo, no caso do alelo *3, este método vai amplificar a banda para este alelo e se interpretará como sendo homozigoto para este alelo, quando na verdade, ele é heterozigoto, segundo o método de seqüenciamento.

Ao analisar os resultados do voluntário 19, observamos que pelo método Tetra Primer temos o genótipo heterozigoto $* 1 / * 4$ e pelo método de seqüenciamento o fenótipo $* 2 / * 10$. $\mathrm{O}$ valor do índice metabólico foi de 0.1218 , caracterizando-se como metabolizador normal. $\mathrm{O}$ 
fato de ter genótipos diferentes por ambos métodos não alterou a atividade enzimática deste voluntário. Quando existe a combinação de um IM e um EM, o resultado é uma atividade enzimática normal, e isto fica em evidência nos dois genótipos, tanto para o heterozigoto *1 / *4 quanto para o *2 / *10. Contudo, causa estranheza observar que no método de seqüenciamento não houve a detecção do alelo *4 para esta amostra. Isto pode ser explicado, de alguma maneira a baixa qualidade do DNA que ficou estocado durante mais de 2 anos.

Ao analisar o voluntário 27, vemos que apresenta um índice metabólico de 1.3421, que é característico de um metabolizador lento. Porém, os resultados das genotipagens pelos dois métodos mostraram dos genótipos diferentes: homozigoto selvagem para os alelos $* 3$ e *4, segundo o método Tetra Primer e heterozigoto $* 2 / * 10$ pelo método de sequienciamento. Este resultado é surpreendente, pois fenotipicamente é um metabolizador lento, e o resultado do seqüenciamento caracterizou um heterozigoto para os alelos *2 e *10. O alelo *10 é um alelo que tem como característica a diminuição da atividade enzimática, porém, quando ele é combinado com alelo $* 2$, de característica normal, o fenótipo predito é normal. Uma possível explicação que no caso deste voluntário, talvez apresente outro polimorfismo diferente dos avaliados pelo método de seqüenciamento e que seja dominante.

A análise do voluntário 9 é peculiar. O estudo do número de cópias revelou que ele apresenta três cópias dos genes $C Y P 2 D 6$, característica de uma atividade enzimática aumentada. A identificação pelo método se seqüenciamento mostrou um heterozigoto para os alelos $* 1$ e $* 2(* 1 / * 2)$, que indica atividade normal. Infelizmente este resultado não pode ser verificado por problemas no estudo da fenotipagem.

A análise do voluntário 56, mostra que foi caracterizado pelo método Tetra Primer como sendo homozigoto para o alelo *1 (selvagem) e homozigoto para o alelo 4 . Pelo método de seqüenciamento ele foi caracterizado como heterozigoto $* 4$ / *5. Este resultado pode ser explicado, ao igual que o caso do voluntário 47, pelo fato de ambas metodologias de genotipagem terem uma abordagem diferente. Como mencionado, o método Tetra Primer amplifica na presença de um alelo a banda correspondente, neste caso o alelo *4, sem discriminar a presença de outros polimorfismos na amostra de DNA. Como nós não tivemos sucesso com este método na avaliação do alelo *5, então não podemos ter a confirmação desse dado pelo método Tetra Primer. Devemos salientar que o alelo *5 tem uma 
característica de deleção para o gene CYP2D6, o que significa que usando os primers específicos para o alelo *4 não pode ser detectado pelo método Tetra Primer. Por tal motivo, se a presença for só de um alelo $* 4$, este método vai amplificar a banda para este alelo e a interpretação é de homozigoto para este alelo, quando na verdade, ele é heterozigoto, segundo o método de seqüenciamento. O valor da fenotipagem foi de 59.5360, valor extremamente grande, característica de um metabolizador lento. A análise do número de cópias revelou que apresenta uma cópia só do gene.

O método Tetra Primer vai gerar duas bandas quando for um homozigoto para o alelo específico e outra banda que é o controle interno da reação, que é o gene selvagem. Contudo, nós não podemos afirmar com certeza que este produto de amplificação é o gene selvagem, pois como condição da PCR, dois primers vai amplificar este gene e os outros primers são os específicos para a variante alélica.

Observamos que, na maioria dos casos, houve uma boa correlação entre os dados fenotípicos e genotípicos. Contudo, essa correlação não foi absoluta. Acreditamos que a adição de novos polimorfismos vai ajudar a aumentar essa correlação. 
7 CONCLUSÃO 
1. Foram genotipados 75 voluntários sadios da região da cidade de Campinas. O estudo mostrou uma alta correlação entre os dos métodos de fenotipagem e genotipagem.

2. O método de genotipagem Tetra Primer mostrou freqüências alélicas similares aos publicados por vários grupos de pesquisa para os alelos $C Y P 2 D 6 * 1, * 3 \mathrm{e} * 4$.

3. O método Tetra Primer não foi satisfatório para a análise dos alelos $C Y P 2 D 6 * 5$ e *6, precisando de alguma amostra de DNA controle que possa validar nossos resultados.

4. A freqüência alélica para o alelo selvagem $C Y P 2 D 6 * 1$ foi 30,66.

5. A freqüência alélica para o alelo $C Y P 2 D 6 * 3$ foi $1.3 \%$

6. A freqüência alélica para o alelo selvagem $C Y P 2 D 6 * 4$ foi $14 \%$.

7. O método de seqüenciamento para a caracterização dos alelos $C Y P 2 D 6 * 1, * 2, * 3$, *4, $* 5, * 6, * 10, * 17$ e *41 mostrou resultados que ajudaram interpretar resultados que não podiam ser entendidos pelo método Tetra Primer.

8. O estudo de número de cópias demonstrou que das 19 amostras seqüenciadas, só uma amostra apresentou 3 cópias do gene $C Y P 2 D 6$, gerando uma atividade enzimática possivelmente aumentada. Uma amostra mostrou correlação entre os métodos de fenotipagem e os dois métodos de genotipagem, sendo considerado um metabolizador lento ou PM. 


\section{REFERÊNCIAS $^{1}$}

1 Gonzalez FJ, Gelboin HV. Role of human cytochromes P450 in the metabolic activation of chemical carcinogens and toxins. Drug Metab Rev. 1994;26(1-2):165-83.

2 Nelson DR, Strobel HW. Evolution of Cytochrome P-450 Proteins. Mol Biol Evol. 1998;5:199.

3 Porter TD, Coon MJ. Cytochrome P-450. Multiplicity of isoforms, substrates, and catalytic and regulatory mechanisms. J Biol Chem. 1991;266(21):13469-72.

4 Coon MJ, Ding XX, Pernecky SJ, Vaz AD. Cytochrome P450: progress and predictions. FASEB J. 1992;6(2):669-73.

5 Phillips KA, Veenstra DL, Oren E, Lee JK, Sadee W. Potential role of pharmacogenomics in reducing adverse drug reactions: a systematic review. JAMA. 2001;286(18):2270-9.

6 Chen Q, Zhang T, Wang JF, Wei DQ. Advances in human cytochrome p450 and personalized medicine. Curr Drug Metab. 2011;12(5):436-44.

7 Bertz RJ, Granneman GR. Use of in vitro and in vivo data to estimate the likelihood of metabolic pharmacokinetic interactions. Clin Pharmacokinet. 1997;32(3):210-58.

8 Nakamura H, Torimoto N, Ishii I, Ariyoshi N, Nakasa H, Ohmori S, Kitada M. CYP3A4 and CYP3A7-mediated carbamazepine 10,11-epoxidation are activated by differential endogenous steroids. Drug Metab Dispos. 2003;31(4):432-8.

9 Rang HP, Dale, MM, Ritter JM, et al. Farmacologia. Rio de Janeiro. Elsevier Editora Ltda. Tradução da Quinta Edição Americana. 2004.

10 Hardman JG, Limbird LE. Goodman \& Gilman's: The Pharmacological Basis of Therapeutics. 10th ed. New York: McGraw-Hill; 2001.

11 Wijnen PA, Op den Buijsch RA, Drent M, Kuijpers PM, Neef C, Bast A, Bekers O, Koek GH. Review article: The prevalence and clinical relevance of cytochrome P450 polymorphisms. Aliment Pharmacol Ther. 2007;26 Suppl 2:211-9. Review. Erratum in: Aliment Pharmacol Ther. 2009;29(3):350.

12 Roden DM, Altman RB, Benowitz NL, Flockhart DA, Giacomini KM, Johnson JA, Krauss RM, McLeod HL, Ratain MJ, Relling MV, Ring HZ, Shuldiner AR, Weinshilboum RM, Weiss ST; Pharmacogenetics Research Network. Pharmacogenomics: challenges and opportunities. Ann Intern Med. 2006;145(10):749-57.

13 Nebert DW. Polymorphisms in drug-metabolizing enzymes: what is their clinical relevance and why do they exist? Am J Hum Genet. 1997;60(2):265-71.

${ }^{1}$ De acordo com:

International Committee of Medical Journal Editors. Uniform requirements for manuscripts submitted to Biomedical Journal: sample references. Available from: http://www.icmje.org [2007 May 22]. 
14 Guengerich FP, Parikh A, Yun CH, Kim D, Nakamura K, Notley LM, Gillam EM. What makes P450s work? Searches for answers with known and new P450s. Drug Metab Rev. 2000;32(3-4):267-81.

15 Rodríguez Arcas MJ, García-Jiménez E, Martínez-Martínez F, Conesa-Zamora P. Role of CYP450 in pharmacokinetics and pharmacogenetics of antihypertensive drugs. Farm Hosp. 2011;35(2):84-92.

16 van der Weide J, Steijns LS. Cytochrome P450 enzyme system: genetic polymorphisms and impact on clinical pharmacology. Ann Clin Biochem. 1999;36(6):722-9.

17 Ingelman-Sundberg M. Pharmacogenetics of cytochrome P450 and its applications in drug therapy: the past, present and future. Trends Pharmacol Sci. 2004;25(4):193-200.

18 Nebert DW, Russell DW. Clinical importance of the cytochromes P450. Lancet. 2002;360(9340):1155-62.

19 Gonzalez FJ, Skoda RC, Kimura S, Umeno M, Zanger UM, Nebert DW, Gelboin HV, Hardwick JP, Meyer UA. Characterization of the common genetic defect in humans deficient in debrisoquine metabolism. Nature. 1988;331(6155):442-6.

20 Nelson, DR. The Cytochrome P450 Homepage. Human Genomics 2009;4:59-65 Available from: http://drnelson.uthsc.edu/CytochromeP450.html [2011 Jun 8].

21 Zhou SF. Polymorphism of human cytochrome P450 2D6 and its clinical significance: Part I. Clin Pharmacokinet. 2009;48(11):689-723.

22 Pirmohamed M, Park BK. Cytochrome P450 enzyme polymorphisms and adverse drug reactions. Toxicology. 2003;192(1):23-32.

23 Nelson DR, Zeldin DC, Hoffman SM, Maltais LJ, Wain HM, Nebert DW. Comparison of cytochrome P450 (CYP) genes from the mouse and human genomes, including nomenclature recommendations for genes, pseudogenes and alternative-splice variants. Pharmacogenetics. 2004;14(1):1-18.

24 Ingelman-Sundberg M, Sim SC, Gomez A, Rodriguez-Antona C. Influence of cytochrome P450 polymorphisms on drug therapies: pharmacogenetic, pharmacoepigenetic and clinical aspects. Pharmacol Ther. 2007;116(3):496-526.

25 Lopes-Cendes I, Guerreiro CA. Pharmacogenetics: reality or fiction? Or are we there yet? Arq Neuropsiquiatr. 2011;69(2A):151-2.

26 Ingelman-Sundberg M, Oscarson M, McLellan RA. Polymorphic human cytochrome P450 enzymes: an opportunity for individualized drug treatment. Trends Pharmacol Sci. 1999;20(8):342-9.

27 Meyer UA. Pharmacogenetics - five decades of therapeutic lessons from genetic diversity. Nat Rev Genet. 2004;5(9):669-76. 
28 Harris H. Polymorphism and protein evolution. The neutral mutation-random drift hypothesis. J Med Genet. 1971;8(4):444-52.

29 Roden DM. Principles in pharmacogenetics. Epilepsia. 2001;42(Suppl 5):44-8.

30 Lodish H, Berk A, Matsudaira P, et al. Biologia Celular e Molecular. Quinta edição. São Paulo. Artmed Editora S.A. 2005.

31 Hanioka N, Kimura S, Meyer UA, Gonzalez FJ. The human CYP2D locus associated with a common genetic defect in drug oxidation: a G1934----A base change in intron 3 of a mutant CYP2D6 allele results in an aberrant 3' splice recognition site. Am J Hum Genet. 1990;47(6):994-1001.

32 Bracco L, Kearsey J. The relevance of alternative RNA splicing to pharmacogenomics. Trends Biotechnol. 2003;21(8):346-53.

33 Ingelman-Sundberg M. Polymorphism of cytochrome P450 and xenobiotic toxicity. Toxicology. 2002;181-182:447-52.

34 McKinnon RA, Evans AM. Cytochrome P450: Pharmacogenetics. Aust J. Hosp Pharm. 2000;30:102-5.

35 Sistonen J, Sajantila A, Lao O, Corander J, Barbujani G, Fuselli S. CYP2D6 worldwide genetic variation shows high frequency of altered activity variants and no continental structure. Pharmacogenet Genomics. 2007;17(2):93-101.

36 Steen VM, Molven A, Aarskog NK, Gulbrandsen AK. Homologous unequal cross-over involving a $2.8 \mathrm{~kb}$ direct repeat as a mechanism for the generation of allelic variants of human cytochrome P450 CYP2D6 gene. Hum Mol Genet. 1995;4(12):2251-7.

37 Zanger UM, Raimundo S, Eichelbaum M. Cytochrome P450 2D6: overview and update on pharmacology, genetics, biochemistry. Naunyn Schmiedebergs Arch Pharmacol. 2004;369(1):23-37.

38 Ingelman-Sundberg M. Genetic polymorphisms of cytochrome P450 2D6 (CYP2D6): clinical consequences, evolutionary aspects and functional diversity. Pharmacogenomics J. 2005;5(1):6-13.

39 Rowland P, Blaney FE, Smyth MG, Jones JJ, Leydon VR, Oxbrow AK, Lewis CJ, Tennant MG, Modi S, Eggleston DS, Chenery RJ, Bridges AM. Crystal structure of human cytochrome P450 2D6. J Biol Chem. 2006;281(11):7614-22.

40 Unwalla RJ, Cross JB, Salaniwal S, Shilling AD, Leung L, Kao J, Humblet C. Using a homology model of cytochrome P450 2D6 to predict substrate site of metabolism. J Comput Aided Mol Des. 2010;24(3):237-56.

41 Lesko LJ, Salerno RA, Spear BB, Anderson DC, Anderson T, Brazell C, Collins J, Dorner A, Essayan D, Gomez-Mancilla B, Hackett J, Huang SM, Ide S, Killinger J, Leighton J, Mansfield E, Meyer R, Ryan SG, Schmith V, Shaw P, Sistare F, Watson M, Worobec A. Pharmacogenetics and pharmacogenomics in drug development and regulatory decision 
making: report of the first FDA-PWG-PhRMA-DruSafe Workshop. J Clin Pharmacol. 2003;43(4):342-58.

42 Hersberger M, Marti-Jaun J, Rentsch K, Hänseler E. Rapid detection of the CYP2D6*3, CYP2D6*4, and CYP2D6*6 alleles by tetra-primer PCR and of the CYP2D6*5 allele by multiplex long PCR. Clin Chem. 2000;46(8 Pt 1):1072-7.

43 Ye S, Humphries S, Green F. Allele specific amplification by tetra-primer PCR. Nucleic Acids Res. 1992;20(5):1152.

44 Ye S, Dhillon S, Ke X, Collins AR, Day IN. An efficient procedure for genotyping single nucleotide polymorphisms. Nucleic Acids Res. 2001;29(17):E88-8.

45 Newton CR, Graham A, Heptinstall LE, Powell SJ, Summers C, Kalsheker N, Smith JC, Markham AF. Analysis of any point mutation in DNA. The amplification refractory mutation system (ARMS). Nucleic Acids Res. 1989;17(7):2503-16.

46 Sachse C, Brockmöller J, Bauer S, Roots I. Cytochrome P450 2D6 variants in a Caucasian population: allele frequencies and phenotypic consequences. Am $\mathrm{J}$ Hum Genet. 1997;60(2):284-95.

47 Stamer UM, Bayerer B, Wolf S, Hoeft A, Stüber F. Rapid and reliable method for cytochrome P450 2D6 genotyping. Clin Chem. 2002;48(9):1412-7.

48 Müller B, Zöpf K, Bachofer J, Steimer W. Optimized strategy for rapid cytochrome P450 2D6 genotyping by real-time long PCR. Clin Chem. 2003;49(10):1624-31.

49 Pusch W, Wurmbach JH, Thiele H, Kostrzewa M. MALDI-TOF mass spectrometry-based SNP genotyping. Pharmacogenomics. 2002;3(4):537-48.

50 Shi Y, Xiang P, Li L, Shen M. Analysis of 50 SNPs in CYP2D6, CYP2C19, CYP2C9, CYP3A4 and CYP1A2 by MALDI-TOF mass spectrometry in Chinese Han population. Forensic Sci Int. 2011;207(1-3):183-7.

51 Jackson PR, Tucker GT, Lennard MS, Woods HF. Polymorphic drug oxidation: pharmacokinetic basis and comparison of experimental indices. $\mathrm{Br} \mathrm{J}$ Clin Pharmacol. 1986;22(5):541-50.

52 Wojtczak A, Rychlik-Sych M, Krochmalska-Ulacha E, Skretkowicz J. CYP2D6 phenotyping with dextromethorphan. Pharmacol Rep. 2007;59(6):734-8.

53 Chládek J, Zimová G, Beránek M, Martínková J. In-vivo indices of CYP2D6 activity: comparison of dextromethorphan metabolic ratios in 4-h urine and 3-h plasma. Eur J Clin Pharmacol. 2000;56(9-10):651-7.

54 Borges S, Li L, Hamman MA, Jones DR, Hall SD, Gorski JC. Dextromethorphan to dextrorphan urinary metabolic ratio does not reflect dextromethorphan oral clearance. Drug Metab Dispos. 2005;33(7):1052-5. 
55 Schmid B, Bircher J, Preisig R, Küpfer A. Polymorphic dextromethorphan metabolism: co-segregation of oxidative O-demethylation with debrisoquin hydroxylation. Clin Pharmacol Ther. 1985;38(6):618-24.

56 Basci NE, Bozkurt A, Kayaalp SO, Sayal A, Isimer A. Omission of the deconjugation step in urine analysis and the unaltered outcome of CYP2D6 phenotyping with dextromethorphan. Eur J Drug Metab Pharmacokinet. 1998;23(1):1-5.

57 Dayer P, Leemann T, Striberni R. Dextromethorphan O-demethylation in liver microsomes as a prototype reaction to monitor cytochrome P-450 db1 activity. Clin Pharmacol Ther. 1989;45(1):34-40.

58 Küpfer A, Schmid B, Pfaff G. Pharmacogenetics of dextromethorphan O-demethylation in man. Xenobiotica. 1986;16(5):421-33.

59 Wolf CR, Smith G. Pharmacogenetics. Br Med Bull. 1999;55(2):366-86.

60 Steen VM, Andreassen OA, Daly AK, Tefre T, Børresen AL, Idle JR, Gulbrandsen AK. Detection of the poor metabolizer-associated CYP2D6(D) gene deletion allele by long-PCR technology. Pharmacogenetics. 1995;5(4):215-23.

61 Ingelman-Sundberg M, Oscarson M, Daly AK, Garte S, Nebert DW. Human cytochrome P-450 (CYP) genes: a web page for the nomenclature of alleles. Cancer Epidemiol Biomarkers Prev. 2001;10(12):1307-8.

62 Prado CM. Desenvolvimento de metodologia para a determinação dos genótipos principais dos genes CYP2D6, CYP2C19 e CYP2C9: aplicação na Farmacogenética. 2009. $141 \mathrm{f}$. Dissertação (Mestrado em Biotecnologia). São Paulo: Instituto de Ciências Biomédicas da Universidade de São Paulo; 2010.

63 Naveen AT, Prasanna T, Farzana BL, Rajan S, Adithan C. CYP2D6 genotype and phenotype relationship in South Indians. J Postgrad Med. 2006;52(4):253-6.

64 Hinrichs JW, Smallegoor WD, van Baalen-Benedek EH, Welker C, van der Weide J. Detection of CYP2D6 polymorphisms $* 9, * 10$, and $* 41$ using ARMS-PCR and their allelic frequencies in 400 psychiatric patients. Clin Chem Lab Med. 2007;45(4):555-7.

65 Sanger F, Nicklen S, Coulson AR. DNA sequencing with chain-terminating inhibitors. Proc Natl Acad Sci U S A. 1977;74(12):5463-7.

66 Altschul SF, Gish W, Miller W, Myers EW, Lipman DJ. Basic local alignment search tool. J Mol Biol. 1990;215(3):403-10.

67 Johansson I, Lundqvist E, Dahl ML, Ingelman-Sundberg M. PCR-based genotyping for duplicated and deleted CYP2D6 genes. Pharmacogenetics. 1996;6(4):351-5.

68 Meijerman I, Sanderson LM, Smits PH, Beijnen JH, Schellens JH. Pharmacogenetic screening of the gene deletion and duplications of CYP2D6. Drug Metab Rev. 2007;39(1):4560 . 
69. Lundqvist E, Johansson I, Ingelman-Sundberg M. Genetic mechanisms for duplication and multiduplication of the human CYP2D6 gene and methods for detection of duplicated CYP2D6 genes. Gene. 1999;226(2):327-38.

70. Løvlie R, Daly AK, Molven A, Idle JR, Steen VM. Ultrarapid metabolizers of debrisoquine: characterization and PCR-based detection of alleles with duplication of the CYP2D6 gene. FEBS Lett. 1996;392(1):30-4.

71 Bernard S, Neville KA, Nguyen AT, Flockhart DA. Interethnic differences in genetic polymorphisms of CYP2D6 in the U.S. population: clinical implications. Oncologist. 2006 Feb;11(2):126-35.

72 Sabbagh A, Darlu P. Data-mining methods as useful tools for predicting individual drug response: application to CYP2D6 data. Hum Hered. 2006;62(3):119-34.

73 Kirchheiner J, Nickchen K, Bauer M, Wong ML, Licinio J, Roots I, Brockmöller J. Pharmacogenetics of antidepressants and antipsychotics: the contribution of allelic variations to the phenotype of drug response. Mol Psychiatry. 2004;9(5):442-73.

74 Lee W, Lockhart AC, Kim RB, Rothenberg ML. Cancer pharmacogenomics: powerful tools in cancer chemotherapy and drug development. Oncologist. 2005;10(2):104-11.

75 de Leon J, Susce MT, Johnson M, Hardin M, Maw L, Shao A, Allen AC, Chiafari FA, Hillman G, Nikoloff DM. DNA microarray technology in the clinical environment: the AmpliChip CYP450 test for CYP2D6 and CYP2C19 genotyping. CNS Spectr. 2009;14(1):1934.

76 Sistonen J, Fuselli S, Palo JU, Chauhan N, Padh H, Sajantila A. Pharmacogenetic variation at CYP2C9, CYP2C19, and CYP2D6 at global and microgeographic scales. Pharmacogenet Genomics. 2009;19(2):170-9.

77 Kohlrausch FB, Gama CS, Lobato MI, Belmonte-de-Abreu P, Callegari-Jacques SM, Gesteira A, Barros F, Carracedo A, Hutz MH. Naturalistic pharmacogenetic study of treatment resistance to typical neuroleptics in European-Brazilian schizophrenics. Pharmacogenet Genomics. 2008;18(7):599-609. 
ANEXOS 


\author{
ANEXO A \\ TERMO DE CONSENTIMENTO \\ Cartesius Desenvolvimento de Pesquisas Clínicas Ltda \\ Galeno Research Unit
}

TERMO DE CONSENTIMENTO LIVRE E ESCLARECIDO

\begin{abstract}
CORRELAÇÃO ENTRE A GENOTIPAGEM DOS ALELOS MAIS COMUNS DO GENE CYP2D6 E A FARMACOCINÉTICA DA DROGA DEXTROMETORFANO EM VOLUNTÁRIOS SADIOS.
\end{abstract}

\title{
I - DESENHO DO ESTUDO E OBJETIVOS
}

A farmacogenética descreve o uso da informação genética para orientar a escolha da terapia farmacológica numa base individual. Assim, pressupõe-se que é possível prever diferenças nas respostas a agentes terapêuticos entre indivíduos a partir de sua constituição genética. Com base neste princípio, a descoberta das variações genéticas específicas associadas a uma resposta terapêutica boa ou inadequada a um determinado fármaco, deverá permitir a individualização das escolhas terapêuticas baseadas no genótipo do indivíduo que regulam a farmacocinética e a farmacodinâmica dos medicamentos. Estudos atuais de farmacogenética têm como objetivo otimizar a eficácia de uma droga e diminuir os efeitos colaterais e a toxicidade. O objetivo deste estudo é investigar uma possível correlação entre os polimorfismos do gene CYP2D6 e a farmacocinética da droga Dextromethorphan com a finalidade de identificar, através de genotipagem, populações que apresentam diferenças significativas nos níveis de absorção de fármacos.

\section{II - PROCEDIMENTOS}

Os participantes desse estudo serão submetidos ao preenchimento de um formulário de identificação e dados clínicos. Será realizada coleta de sangue periférico para Análise Hematológica (exames de hemoglobina, hematócrito, contagem total e diferencial de leucócitos, contagem de glóbulos vermelhos, contagem de plaquetas); Análise Bioquímica (exames de uréia, creatinina, bilirrubina total, proteínas totais, albumina, glicose em jejum, fosfatase alcalina, SGOT, SGTP, colesterol total, triglicerídeos, ácido úrico e $\gamma \mathrm{GT}$ ); Análise de Urina (exame de urina I e experimentos de fenotipagem); Análise Sorológica [exames de hepatite B e C, HIV (1+2) e b-HCG nas mulheres]; Genotipagem CYP2D6; e experimentos de farmacocinética.

\section{III - DESCONFORTOS E RISCOS ESPERADOS}

O desconforto será pequeno, visto que o procedimento mais doloroso é a coleta de uma amostra de sangue como é feito nos exames de sangue normais. Será colhida apenas uma amostra de sangue de cerca de $5 \mathrm{ml}$, em uma seringa; portanto, sempre que possível, uma única punção será realizada. 


\section{IV - BENEFÍCIOS}

A correlação entre polimorfismos de genes relacionados ao metabolismo (oxidação) de drogas e a sua repercussão farmacocinética (fase I do desenvolvimento clínico), em indivíduos voluntários sadios, podem auxiliar no tratamento (escolha do medicamento e de sua posologia) tanto da população em geral quanto de pacientes que fazem o uso prolongado de um determinado tipo de medicamento, pela possibilidade de uma pré-seleção mais adequada do fármaco a ser prescrito. A existência de um banco de dados disponível das características genéticas de cada indivíduo poderia contribuir para uma seleção de drogas mais adequada do que a seleção baseada na tentativa e erro, minimizando o aparecimento de efeitos adversos, contribuindo inclusive em termos econômicos. Este procedimento poderia trazer benefícios para o sistema de saúde pela diminuição substancial de internações para o tratamento de efeitos colaterais.

\section{V - GARANTIA DE ESCLARECIMENTOS}

Todas as informações a respeito do andamento do trabalho (exames de sangue, consultas, resultados, riscos) serão comunicados aos participantes assim como, quaisquer outras dúvidas serão esclarecidas. O principal investigador é o Dr. Gilberto de Nucci, professor do Depto de Farmacologia da USP e da UNICAMP, responsável pela Cartesius Desenvolvimento de Pesquisas Clínicas Ltda (Av. Prof. Lineu Prestes, 1524 -São Paulo / SP, fone: (11) 30917493) e Galeno Research Unit (Rua Latino Coelho, 1301 - Parque TaquaralCampinas / SP, fone: (19) 32427133). Se houver alguma consideração ou dúvida sobre a ética da pesquisa, deve-se entrar em contato com o Comitê de Ética em Pesquisa (CEP) da Universidade Estadual de Campinas (Rua: Tessália Vieira de Camargo, 126 - Cidade Universitária - Campinas - SP, fone: (19) 37888936, e-mail cep@ fcm.unicamp.br).

\section{VI - LIBERDADE DE RETIRAR O CONSENTIMENTO}

A autorização para realização do estudo pode ser retirada no momento em que o participante desejar, sem necessidade de qualquer explicação e sem que deixe de receber orientação, tratamentos ou resultados já obtidos.

\section{VII - SEGURANÇA DO SIGILO}

Toda a informação a respeito do participante e seus exames será mantida em sigilo com o intuito de manter a privacidade do mesmo. O Centro de Bioequivalência não identificará o voluntário por ocasião da exposição e / ou publicação dos resultados.

\section{VIII - COMPROMISSO DE ATUALIZAR A INFORMAÇÃO}

As informações serão fornecidas de maneira atualizada visando um maior esclarecimento dos familiares e até uma eventual mudança de opinião em continuar ou não participando do projeto.

\section{IX - DISPONIBILIDADE DE TRATAMENTO MÉDICO}

Todos os participantes receberão acompanhamento médico necessário, assim como o direito de se manterem atualizados sobre os resultados parciais da pesquisa ou de resultados que sejam de conhecimento dos pesquisadores. Em caso de dano pessoal, diretamente causados 
pelos procedimentos ou tratamentos propostos neste estudo, o participante tem direito a tratamento médico bem como às indenizações legalmente estabelecidas.

\section{X - GASTOS}

Todos os procedimentos médicos e de diagnóstico laboratorial pertinentes à pesquisa serão pagos sem, portanto, qualquer gasto por parte do participante.

\section{XI - COMPROMISSO DO PESQUISADOR}

O pesquisador responsável se compromete a utilizar os dados e o material coletado somente para esta pesquisa.

\section{TERMO DE CONSENTIMENTO}

$\mathrm{Eu}$, anos, declaro ter lido a carta de informação a respeito do PROJETO DE PESQUISA: CORRELAÇÃO ENTRE A GENOTIPAGEM DOS ALELOS MAIS COMUNS DO GENE MDR1 E A FARMACOCINÉTICA DA DROGA DEXTROMETHORPHAN EM VOLUNTÁRIOS SADIOS.

Acredito ter sido suficientemente esclarecido a respeito das informações que li ou que me foram lidas descrevendo o estudo. Ficaram claros quais são os propósitos desta pesquisa, os procedimentos a serem realizados, seus desconfortos e riscos, as garantias de confidencialidade e de esclarecimentos permanentes. Ficou claro também que a minha participação é isenta de despesas e que tenho garantia de acesso a tratamento hospitalar quando necessário. Concordo voluntariamente em participar deste estudo e poderei retirar o meu consentimento a qualquer momento, antes ou durante o mesmo, sem penalidades, prejuízo ou perda de qualquer benefício que eu possa ter adquirido, ou no meu entendimento neste serviço.

Assinatura do paciente ou representante legal

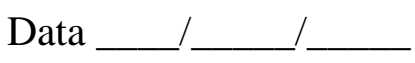

Assinatura da testemunha

Data

Declaro que obtive de forma apropriada e voluntária o Consentimento Livre e Esclarecimento deste paciente ou representante legal para a participação neste estudo.

Data /

Assinatura da pessoa responsável pelo atendimento 


\section{ANEXO B \\ Índice Metabólico de Biotransformação}

\begin{tabular}{|c|c|}
\hline Identificação & MR \\
\hline Vol 1 & 0,09674306 \\
\hline Vol 2 & 0,08288191 \\
\hline Vol 3 & 0,40327869 \\
\hline Vol 4 & 0,0283 \\
\hline Vol 5 & 0,27513514 \\
\hline Vol 6 & 0,04379391 \\
\hline Vol 7 & 0,03303571 \\
\hline Vol 8 & 0 \\
\hline Vol 9 & 0,04336788 \\
\hline Vol 10 & 0,10366972 \\
\hline Vol 11 & 0 \\
\hline Vol 12 & 0,20347222 \\
\hline Vol 13 & 0,02441176 \\
\hline Vol 14 & 0,12303981 \\
\hline Vol 15 & 0,11504425 \\
\hline Vol 16 & 0,14933775 \\
\hline Vol 17 & 0,12179487 \\
\hline Vol 18 & 3,77260982 \\
\hline Vol 19 & 0,0202518 \\
\hline
\end{tabular}

\begin{tabular}{|l|c|}
\hline Identificação & MR \\
\hline Vol 20 & 0,14281525 \\
\hline Vol 21 & 0,06432432 \\
\hline Vol 22 & 0 \\
\hline Vol 23 & 1,8321392 \\
\hline Vol 24 & 0,03106667 \\
\hline Vol 25 & 1,34210526 \\
\hline Vol 26 & 0,03295455 \\
\hline Vol 27 & 35,4494382 \\
\hline Vol 28 & 0,1480315 \\
\hline Vol 29 & 0,05635514 \\
\hline Vol 30 & 0,26893204 \\
\hline Vol 31 & 0,13886463 \\
\hline Vol 32 & 0,23314121 \\
\hline Vol 33 & 0,03164103 \\
\hline Vol 34 & \\
\hline Vol 35 & 0,20930233 \\
\hline Vol 36 & \\
\hline Vol 37 & \\
\hline Vol 38 & \\
\hline
\end{tabular}


ANEXO B (continuação)

\section{Índice Metabólico de Biotransformação}

\begin{tabular}{|l|c|}
\hline Identificação & MR \\
\hline Vol 39 & 0,01632546 \\
\hline Vol 40 & 0,16492891 \\
\hline Vol 41 & 0,02229167 \\
\hline Vol 42 & 0,0561165 \\
\hline Vol 43 & 24,8214286 \\
\hline Vol 44 & 0,11509009 \\
\hline Vol 45 & 0,07913043 \\
\hline Vol 46 & 13,9922481 \\
\hline Vol 47 & 0,14242424 \\
\hline Vol 48 & 0,11259259 \\
\hline Vol 49 & 0,21805556 \\
\hline Vol 50 & 0,15139319 \\
\hline Vol 51 & 0,09076923 \\
\hline Vol 52 & 59,5360825 \\
\hline Vol 53 & 0,02232416 \\
\hline Vol 54 & 0,04510989 \\
\hline Vol 55 & \\
\hline Vol 56 & \\
\hline Vol 57 & \\
\hline & \\
\hline
\end{tabular}

\begin{tabular}{|c|c|}
\hline Identificação & MR \\
\hline Vol 58 & 0,20484581 \\
\hline Vol 59 & 0,15736041 \\
\hline Vol 60 & 0,02832618 \\
\hline Vol 61 & 0,10898204 \\
\hline Vol 62 & 0,06080402 \\
\hline Vol 63 & 0,39192399 \\
\hline Vol 64 & 0,06682243 \\
\hline Vol 65 & 0,03594444 \\
\hline Vol 66 & 0,03714286 \\
\hline Vol 67 & 0 \\
\hline Vol 68 & 0,24273504 \\
\hline Vol 69 & 0,51361868 \\
\hline Vol 70 & 0 \\
\hline Vol 71 & 0,10296296 \\
\hline Vol 72 & 0,05953757 \\
\hline Vol 73 & 0 \\
\hline Vol 74 & 0,13918919 \\
\hline Vol 75 & 20,6578947 \\
\hline
\end{tabular}




\section{ANEXO C \\ Eletroferogramas de alguns alelos}

Eletrotroferograma referente ao seqüenciamento da amostra $\mathbf{3 8}$ indicando a base polimórfica 100C $>\mathrm{T}$. Indivíduo heterozigoto CT

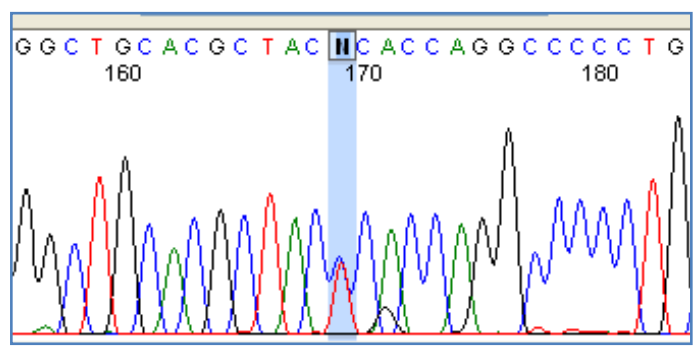

Eletroferograma referente ao seqüenciamento da amostra $\mathbf{3 5}$ indicando a base polimórfica $100 \mathrm{C}>\mathrm{T}$. Indivíduo homozigoto TT

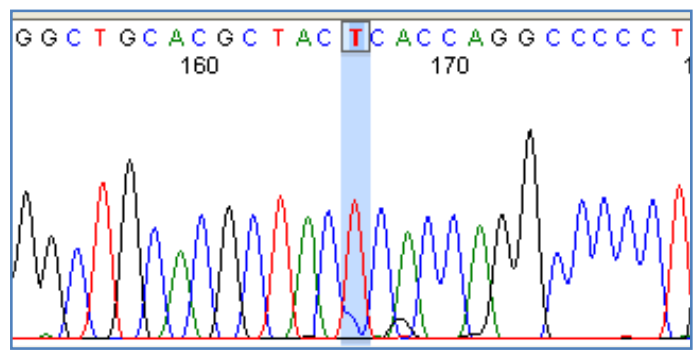

Eletroferograma referente ao seqüenciamento da amostra 21 indicando a base polimórfica $1846 \mathrm{G}>\mathrm{A}$. Indivíduo homozigoto GG

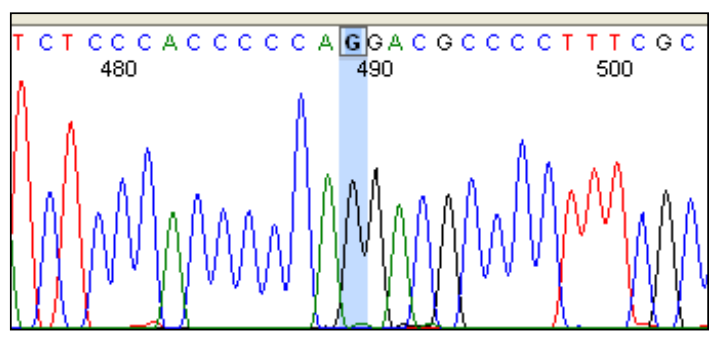

Eletroferograma referente ao seqüenciamento da amostra 21 indicando a base polimórfica 2988G>A. Indivíduo heterozigoto GA

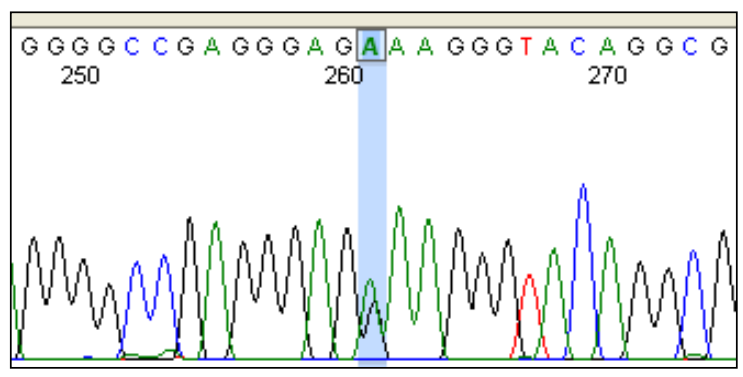


ANEXO D

Haplótipos gerados de pelas reações de Seqüienciamento e Atividade Enzimática $($ Vol = Voluntário $)$

\begin{tabular}{|c|c|c|c|c|c|c|c|c|c|c|c|}
\hline & Alelo & $* 2$ & $* 4, * 10$ & $* 17$ & $* 2 * 4 * 10 * 17 * 41$ & $* 4$ & $* 3$ & $* 41, * 2, * 17$ & $* 41$ & $* 2, * 10, * 17, * 41$ & \\
\hline & alelo & $\begin{array}{c}- \\
1584 \\
\end{array}$ & 100 & 1023 & 1661 & 1846 & 2549 & 2850 & 2988 & 4180 & Enzima \\
\hline & $* 1$ & C & $\mathrm{C}$ & $\mathrm{C}$ & G & $\mathrm{G}$ & A & $\mathrm{C}$ & G & G & NORMAL \\
\hline & $* 2 \mathrm{D}$ & C & $\mathrm{C}$ & $\mathrm{C}$ & G & G & A & $\mathrm{T}$ & G & $\mathrm{C}$ & \\
\hline & $* 2$ & G & $\mathrm{C}$ & $\mathrm{C}$ & $\mathrm{C}$ & G & A & $\mathbf{T}$ & G & C & NORMAL \\
\hline & $* 3$ & C & $\mathrm{C}$ & $\mathrm{C}$ & G & G & -- & $\mathrm{C}$ & G & G & NONE \\
\hline & $* 4$ & $\mathrm{C}$ & $\mathbf{T}$ & $\mathrm{C}$ & $\mathrm{C}$ & A & A & $\mathrm{C}$ & $\mathrm{G}$ & $\mathrm{C}$ & NONE \\
\hline & $* 5$ & $\mathrm{C}$ & - & - & & - & - & - & - & - & NONE \\
\hline & $* 10$ & $\mathrm{C}$ & $\mathbf{T}$ & $\mathrm{C}$ & $\mathrm{C}$ & G & A & $\mathrm{C}$ & G & $\mathrm{C}$ & DECR \\
\hline & $* 17$ & C & $\mathrm{C}$ & $\mathbf{T}$ & C & G & A & $\mathbf{T}$ & G & C & $\overline{D E C R}$ \\
\hline & $* 41$ & C & $\mathrm{C}$ & $\mathrm{C}$ & $\mathrm{C}$ & G & A & $\mathbf{T}$ & A & C & DECR \\
\hline Vol & & & & & & & & & & & \\
\hline 2 & $* 2 * 10$ & $\mathrm{CG}$ & $\mathrm{T}$ & $\mathrm{C}$ & $\mathrm{C}$ & G & & $\mathrm{CT}$ & G & & NORMAL \\
\hline 7 & $* 1 * 2$ & CG & $\mathrm{C}$ & $\mathrm{C}$ & CG & & & CT & G & & NORMAL \\
\hline 9 & $* 1 * 2$ & CG & & $\mathrm{C}$ & & & & CT & G & & AUMENT \\
\hline 18 & $\begin{array}{c}* 2 * 1 \\
0\end{array}$ & CG & $\mathrm{T}$ & $\mathrm{C}$ & $\mathrm{CC}$ & & & CT & G & & NORMAL \\
\hline 19 & $* 1 * 1$ & $\mathrm{C}$ & $\mathrm{C}$ & $\mathrm{C}$ & G & G & & $\mathrm{C}$ & G & & NORMAL \\
\hline 21 & $* 1 * 41$ & $\mathrm{C}$ & $\mathrm{C}$ & $\mathrm{C}$ & CG & G & & CT & GA & & NORMAL \\
\hline 27 & $* 2 * 10$ & CG & $\mathrm{T}$ & $\mathrm{C}$ & $\mathrm{C}$ & G & & CT & G & & NORMAL \\
\hline 28 & --- & $\mathrm{C}$ & & $\mathrm{C}$ & & & & $\mathrm{C}$ & G & & --- \\
\hline 35 & $* 2 * 4$ & $\mathrm{CG}$ & $\mathrm{T}$ & $\mathrm{C}$ & $\mathrm{CC}$ & GA & & $\mathrm{CT}$ & G & & NORMAL \\
\hline 36 & $* 1 * 1$ & $\mathrm{C}$ & $\mathrm{C}$ & $\mathrm{C}$ & G & G & & $\mathrm{C}$ & G & & NORMAL \\
\hline 38 & $* 1 * 4$ & $\mathrm{C}$ & CT & $\mathrm{C}$ & CG & GA & & $\mathrm{C}$ & G & & NORMAL \\
\hline 39 & $* 2 * 4$ & CG & $\mathrm{T}$ & $\mathrm{C}$ & $\mathrm{CC}$ & GA & & CT & G & & NORMAL \\
\hline 44 & --- & $\mathrm{C}$ & $\mathrm{C}$ & $\mathrm{C}$ & & & & $\mathrm{CT}$ & $\mathrm{G}$ & & --- \\
\hline 46 & $* 1 * 2$ & $\mathrm{CG}$ & $\mathrm{C}$ & $\mathrm{C}$ & & & & CT & G & & --- \\
\hline 47 & $* 3 * 5$ & $\mathrm{C}$ & $\mathrm{C}$ & $\mathrm{C}$ & G & G & & $\mathrm{C}$ & G & & NULA \\
\hline 55 & $* 2$ & $\mathrm{CG}$ & $\mathrm{C}$ & $\mathrm{C}$ & G & G & & $\mathrm{CT}$ & G & & --- \\
\hline 56 & $* 4 * 5$ & $\mathrm{C}$ & $\mathrm{T}$ & $\mathrm{C}$ & $\mathrm{C}$ & A & & $\mathrm{C}$ & $\mathrm{G}$ & & NULA \\
\hline 70 & $* 1$ & $\mathrm{C}$ & $\mathrm{C}$ & $\mathrm{C}$ & G & G & & $\mathrm{C}$ & G & & --- \\
\hline 74 & --- & $\mathrm{C}$ & & $\mathrm{C}$ & & & & $\mathrm{C}$ & G & & --- \\
\hline
\end{tabular}

